JOSÉ GUILHERME FRANCHI

\title{
APLICAÇÃO DE TURFA NA RECUPERAÇÃO DE SOLOS DEGRADADOS PELA MINERAÇÃO DE AREIA
}

Dissertação apresentada à Escola Politécnica da Universidade de São Paulo para obtenção do título de Mestre em Engenharia

Área de Concentração:

Engenharia Mineral

Orientador:

Prof. Dr. José Renato Baptista de Lima

São Paulo 2000 
À

Adair 


\section{AGRADECIMENTOS}

Ao Prof. Dr. José Renato Baptista de Lima pela orientação

Ao Geólo Samuel Sussumu Agena pelas profícuas discussões acerca dos ensaios físico-hídricos

Ao Geólo Zeno Hellmeister Jr. pelo apoio

À Geóla Gabriela Campos Fronzaglia pelas análises mineralógicas por difração de raios- $X$

À Químª Giuliana Ratti pelas análises químicas por fluorescência de raios- $X$

Ao Geólo Henrique Kahn pelas análises para determinação da distribuição de tamanho de partículas (Malvern)

Ao Eng o de Minas Roberto Tadeu Lazzari pelo apoio e amizade

À Agrônª Marina Inagaki pelo apoio nas análises para determinação do efeito tampão

Ao Geólo Carlos Alberto Ikeda Oba, pelas análises de P por colorimetria

Ao Químº Reynaldo Arbue Pini, pelas análises por espectrofotometria de absorção atômica

Ao Prof. Manoel Roberto Fernandes da Silva, pela revisão do português

À Maria Cristina Martinez Bonesio, pela revisão das referências bibliográficas

Aos técnicos Reginaldo Passos Cruz, Antônio Angelini Filho (Tico), Alfredo dos Santos Freitas e Celso Pinto Braga pelo apoio nos trabalhos laboratoriais 
Ficha catalográfica

Franchi, José Guilherme

Aplicação de turfa na recuperação de solos degradados pela mineração de areia. São Paulo, 2000.

$103 p$.

Dissertação (Mestrado) - Escola Politécnica da Universidade de São Paulo. Departamento de Engenharia de Minas.

1. Recuperação de Áreas (Mineração) 2. Mineração - Controle Ambiental 3. Mineração - Turfa I. Universidade de São Paulo. Escola Politécnica. Departamento de Engenharia de Minas II.t 
Nome do arquivo: capa_dissert_1

Pasta: $\quad$ C:ICŌEGIAD̄OSIPOLIJJ.Guilherme

Modelo: $\quad$ C:IDocuments and SettingslclientelDados de aplicativos\Microsoft\Modelos\Normal.dot

Título:

JOSÉ GUILHERME FRANCHI

Assunto:

Autor:

ADAIR

Palavras-chave:

Comentários:

Data de criação: $\quad 7 / 12 / 200116: 46$

Número de alterações: 2

Última gravação: 7/12/2001 16:46

Gravado por: jfranchi

Tempo total de edição: 0 Minutos

Última impressão: 9/2/2001 10:14

Como a última impressão

Número de páginas: 4

Número de palavras: 283 (aprox.)

Número de caracteres:1.617 (aprox.) 


\section{SUMÁRIO}

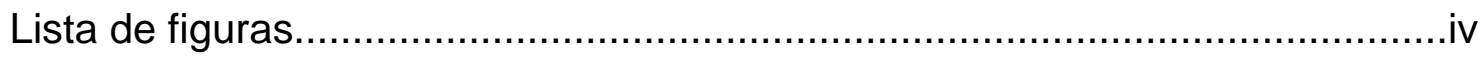

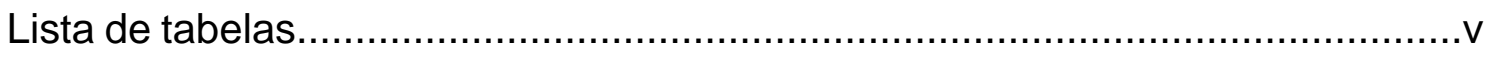

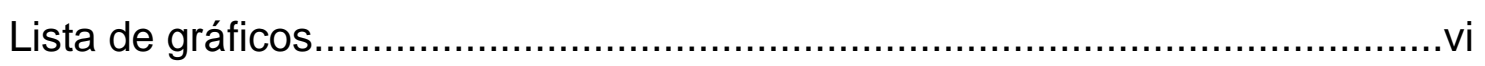

Lista de fotografias..................................................................................

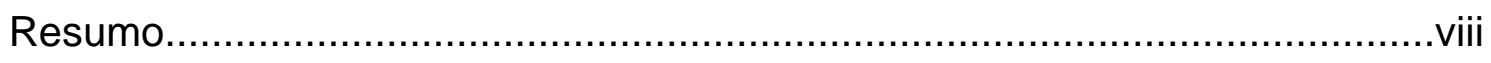

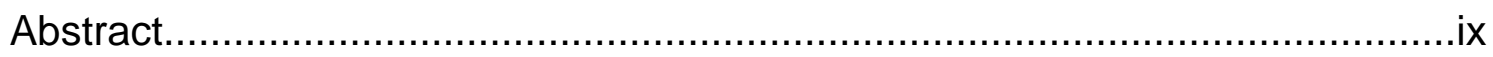

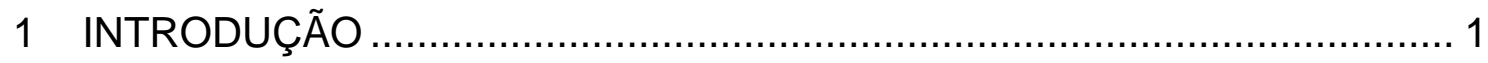

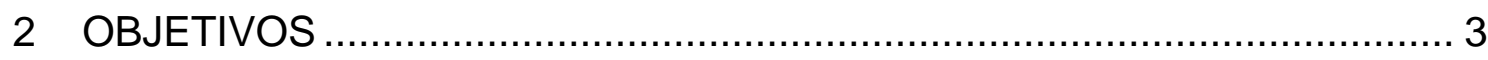

3 MOTIVAÇÃO E HIPÓTESES DE TRABALHO............................................. 4

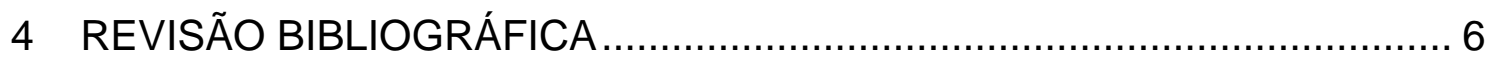

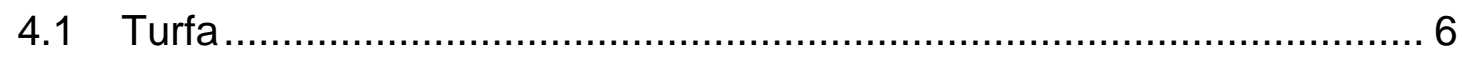

4.2 Propriedades agronômicas conferidas pelo uso de húmus ................... 15

4.3 Recuperação de áreas degradadas ................................................. 19

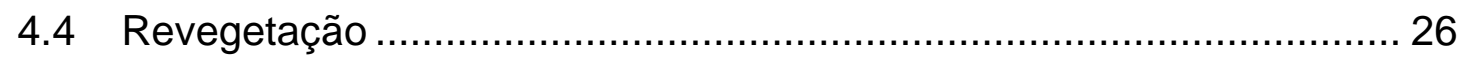

4.5 O uso de matéria orgânica em revegetação de áreas degradadas...... 29

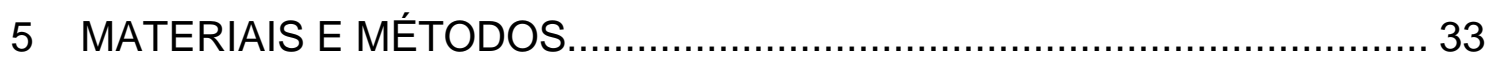

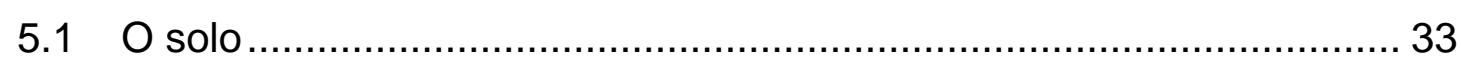

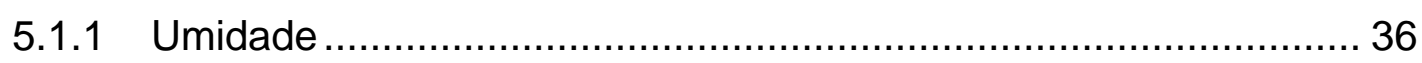

5.1.2 Análise mineralógica por difração de raios- $X$................................ 36

5.1.3 Determinação do tamanho de partículas ....................................... 38

5.1.4 Análise química por fluorescência de raios-X................................ 39

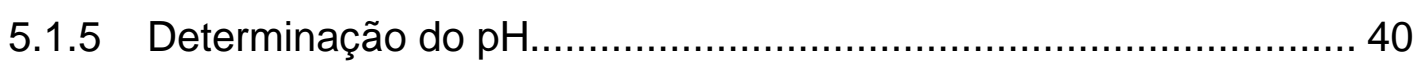

5.1.6 Determinação da Capacidade de Troca de Cátions, V(\%) e m(\%) 40

5.1.7 Determinação da densidade real das partículas ........................... 42

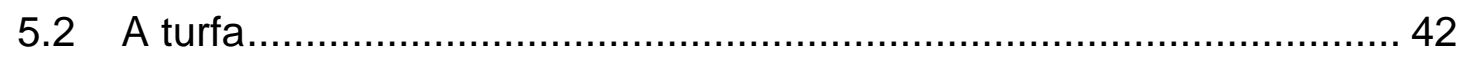

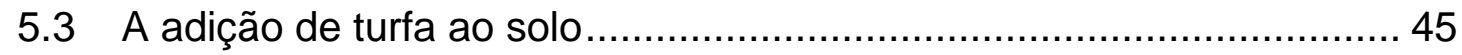

5.4 Conformação das amostras aos ensaios físicos ................................ 46

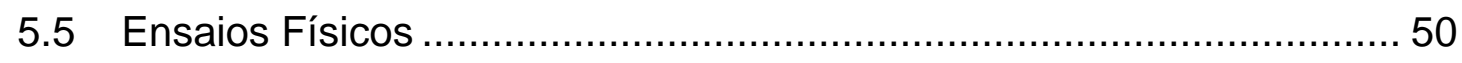

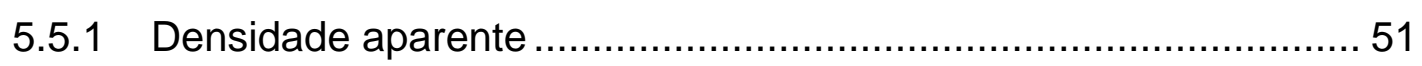




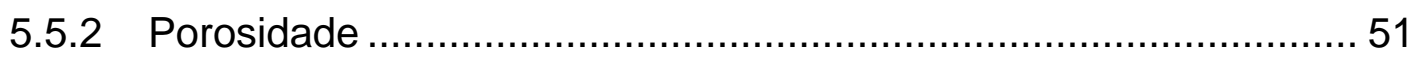

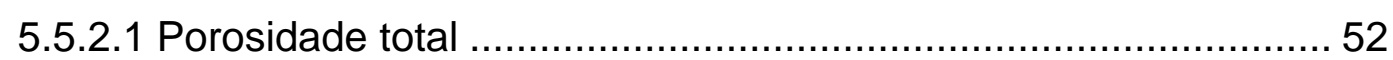

5.5.2.2 Distribuição do tamanho dos poros: macro, meso e

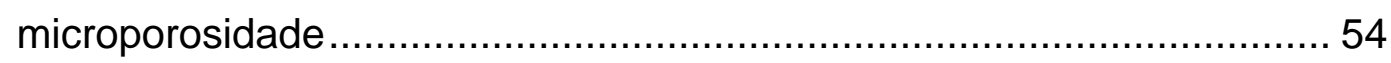

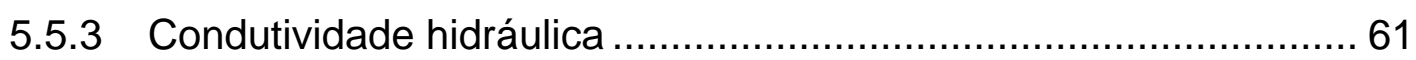

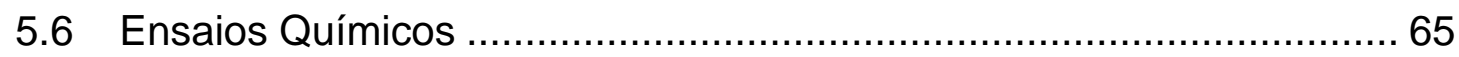

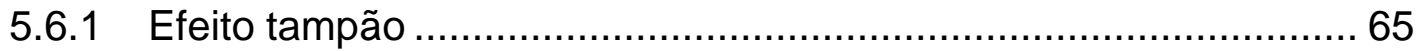

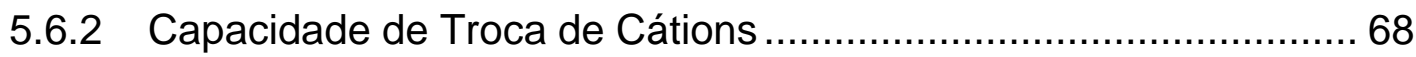

5.6.2.1 Análise química por espectrofotometria de absorção atômica .... 70

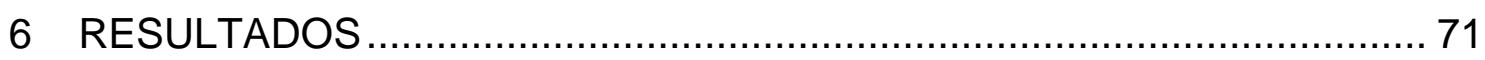

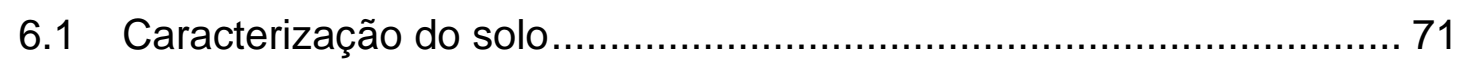

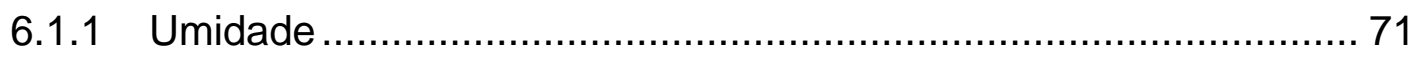

6.1.2 Análise mineralógica por difração de raios-X ............................... 71

6.1.3 Determinação do tamanho das partículas .................................... 76

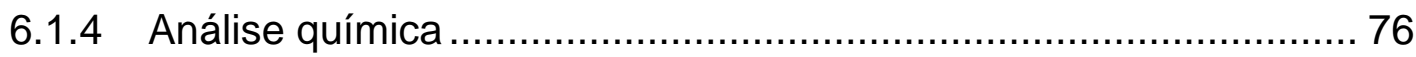

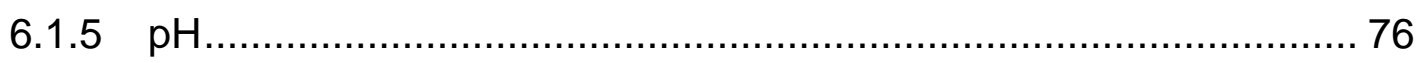

6.1.6 Capacidade de Troca de Cátions, V (\%) e m (\%)......................... 77

6.1.7 Densidade das partículas ........................................................ 77

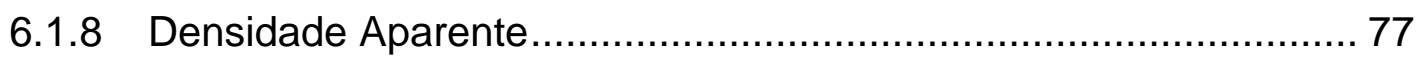

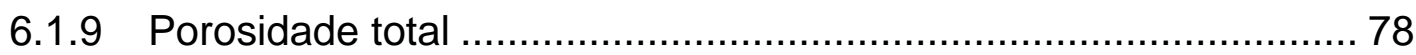

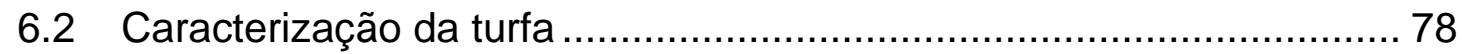

6.2.1 Grau de decomposição ......................................................... 78

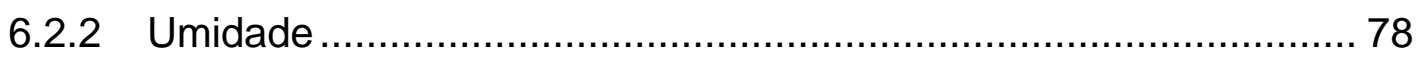

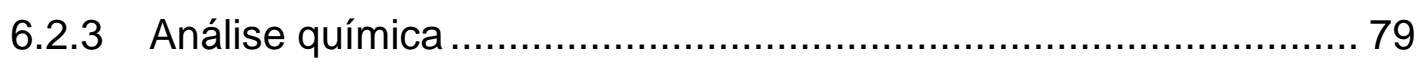

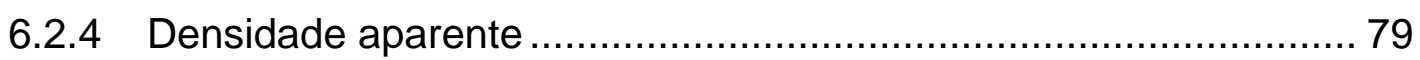

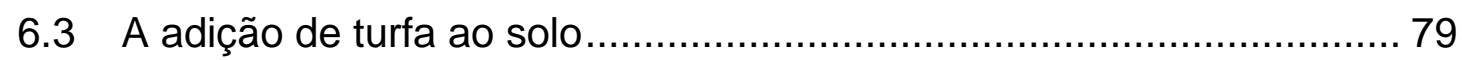

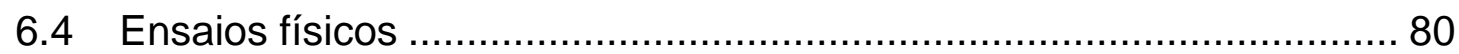

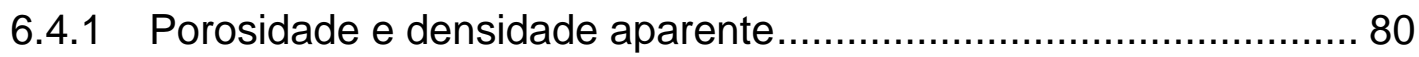

6.4.2 Condutividade hidráulica ......................................................... 84

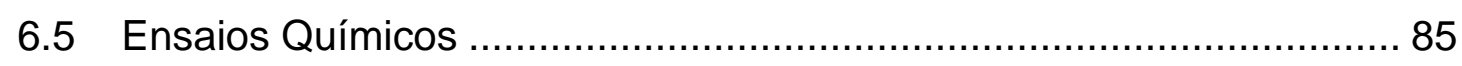

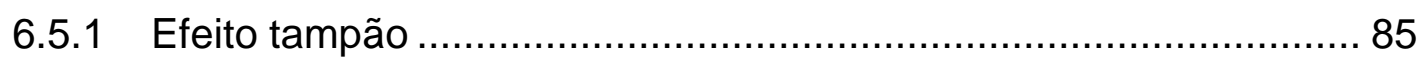

6.5.2 Capacidade de Troca de Cátions .................................................. 87

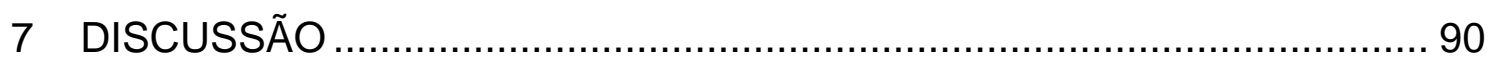




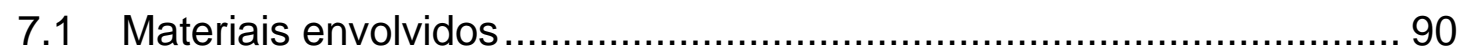

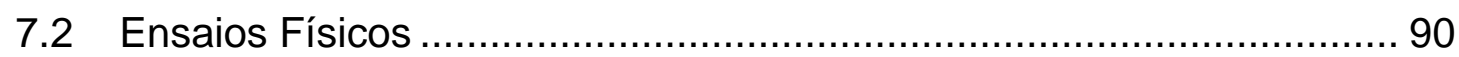

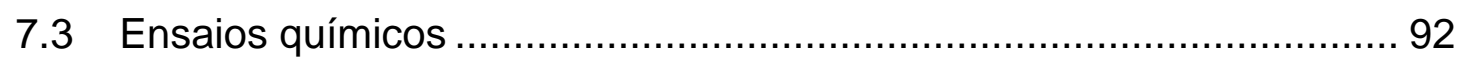

7.4 Sugestões para trabalhos futuros................................................ 96

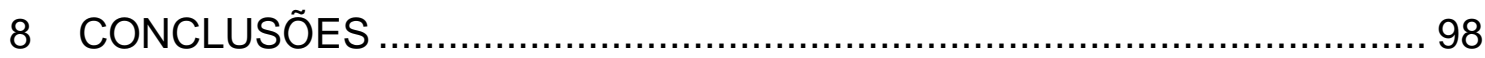

REFERÊNCIAS BIBLIOGRÁFICAS .............................................. 100 


\section{LISTA DE FIGURAS}

Fig. 1 - processo de formação de turfeiras em lagoas (IPT, 1979).................. 8

Fig. 2 - formação de turfeiras em áreas de inundação (IPT, 1979) .................. 9

Fig. 3 - estrutura hipotética do ácido húmico (STEVENSON, 1994 modificada

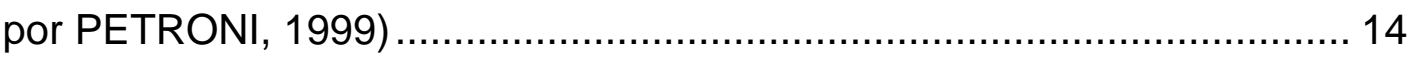

Fig. 4 - (a) efeito do impacto de uma gota de água sobre um grumo de solo; (b) formação do adensamento pela sedimentação de argila carreada pela água de infiltração (mod. de PRIMAVESI, 1984)............................................. 22

Fig. 5 - dispositivo de compactação (mod. de BSI, 1967) ….......................... 47

Fig. 6 - capilar imerso em água (REICHARDT, 1985) ……......................... 55

Fig. 7 - esquema ilustrativo do funil de Haines - ensaio de dessorção (mod. de

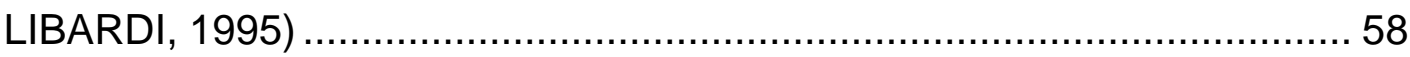

Fig. 8 - câmara de pressão de Richards (mod. de LIBARDI, 1995) ................. 60

Fig. 9 - esquema ilustrativo da Lei de Darcy (CURY, 1953) ........................... 63

Fig. 10 - diagrama do sistema de carga constante para medida da condutividade (mod. de LIBARDI, 1995) 65

Fig. 11 - superposição do padrão difratométrico da caulinita ao difratograma 72

Fig. 12 - superposição do padrão difratométrico do quartzo ao difratograma . 72

Fig. 13 - superposição do padrão difratométrico da albita ao difratograma..... 73

Fig. 14 - superposição do padrão difratométrico do microclíneo ao difratograma 73

Fig. 15 - superposição do padrão difratométrico da biotita ao difratograma.... 74

Fig. 16 - superposição do padrão difratométrico da gibsita ao difratograma ... 74

Fig. 17 - superposição do padrão difratométrico do diopsídio ao difratograma 75

Fig. 18 - superposição dos padrões difratométricos de todos os minerais ao difratograma 75 


\section{LISTA DE TABELAS}

Tab. 1 - possíveis alterações físicas e químicas em solos com a adição de turfa.

Tab. 2 - sistemas de classificação de turfa................................................ 11

Tab. 3 - dimensões das peças utilizadas no procedimento de compactação.. 49

Tab. 4 - características do calcário dolomítico utilizado no estudo do efeito

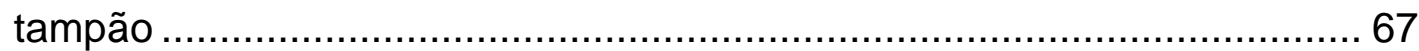

Tab. 5 - composição química da solução estoque ......................................... 69

Tab. 6 - análise química do solo por FRX ……….................................... 76

Tab. 7 - valores obtidos na determinação da CTC do solo............................... 77

Tab. 8 - valores de densidade aparente $\left(\rho_{b}\right)$ para o solo ................................. 77

Tab. 9 - valores de porosidade total para o solo .......................................... 78

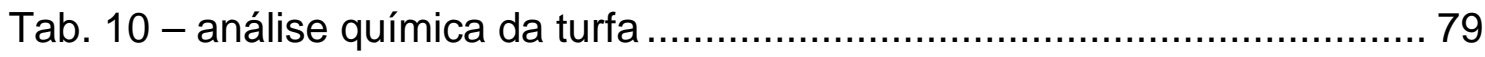

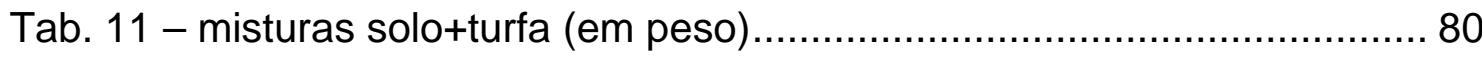

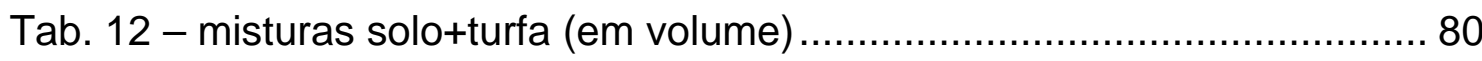

Tab. 13 - valores obtidos nos ensaios de retenção de água à condição de compactação de 15 movimentos de queda........................................... 81

Tab. 14 - porosidades obtidas à condição de compactação de 15 movimentos de queda 81

Tab. 15 - valores obtidos nos ensaios de retenção de água à condição de compactação de 5 movimentos de queda.

Tab. 16 - porosidades obtidas à condição de compactação de 5 movimentos de queda 82

Tab. 17 - valores obtidos nos ensaios de condutividade hidráulica................. 84

Tab. 18 - adição de calcário dolomítico às misturas......................................... 85

Tab. 19 - pH's das misturas em função da adição de calcário dolomítico ........ 86

Tab. 20 - valores de $\mathrm{pH}$ das misturas em função da concentração de $\mathrm{NaOH} .87$

Tab. 21 - CTC das misturas solo+turfa+solução policatiônica, após lavagem 87

Tab. 22 - análises químicas dos filtrados provenientes da lavagem das misturas aditivadas com a solução policatiônica (valores em mg/Kg) 89 


\section{LISTA DE GRÁFICOS}

Gráfico 1 - porosidades à condição de 15 movimentos de queda ................... 83

Gráfico 2 - porosidades à condição de 5 movimentos de queda.................... 83

Gráfico 3 - condutividade hidráulica à condição de 5 movimentos de queda.. 84

Gráfico 4 - pH das misturas em função da adição de calcário dolomítico ........ 86

Gráfico 5 - pH das misturas em função da concentração de $\mathrm{NaOH}$................ 88 


\section{LISTA DE FOTOGRAFIAS}

Foto 1 - área em recuperação ambiental, podendo-se notar mudas de pioneiras recém-transplantadas

Foto 2 - mesmo local da foto anterior, onde foram coletadas as amostras de solo 35

Foto 3 - campo de extração de turfa. 43

Foto 4 - operação de extração comercial do minério. 43

Foto 5 - homogeneização da turfa em pilhas alongadas. 44

Foto 6 - adição de turfa ao solo 45

Foto 7 - conjunto utilizado na compactação das amostras 48

Foto 8 - conjunto de compactação montado, ao lado dos cilindros, anéis e do tubo guia 49

Foto 9 - funis de Haines de placa porosa utilizados no ensaio de dessorção à tensão de sucção de $30 \mathrm{~cm} \mathrm{H}_{2} \mathrm{O}$ 59

Foto 10 - câmaras de Richards utilizadas na dessaturação de amostras de solo a tensões superiores a $100 \mathrm{~cm} \mathrm{H}_{2} \mathrm{O}$; os modelos de menor tamanho são dimensionados para suportar pressões maiores.

Foto 11 - detalhe da câmara salientando o tubo de saída d'água 62

Foto 12 - aparato laboratorial utilizado nos ensaios para determinação da condutividade hidráulica 


\section{RESUMO}

A recuperação ambiental de áreas exploradas pela mineração de areia na região do Vale do Paraíba, Estado de São Paulo, constitui anseio popular, obrigação constitucional e fator de diferenciação dentro da mais moderna visão empresarial.

Este trabalho estuda a aplicação de turfa como um melhorador de solos na etapa final do processo de recuperação destas áreas: o restabelecimento da vegetação nativa.

O interesse surgiu da experiência de trabalho do autor com pesquisa mineral e tecnológica desta substância, além da observação e acompanhamento de alguns projetos de revegetação nestas áreas, tidas como ambientalmente sensíveis e onde os solos apresentam-se, via de regra, improdutivos; sua utilização representou, nestes casos, a diferença entre o sucesso e a necessidade de replantio.

Apresenta-se uma revisão bibliográfica sobre turfa e suas propriedades agronômicas, bem como acerca da utilização de matéria orgânica na revegetação de áreas degradadas.

O estudo constituiu um comparativo entre resultados de ensaios efetuados em amostras de solo provenientes de área abandonada pela mineração de areia, homogeneizadas em laboratório em seu estado original (branco), de um lado, e com adição de turfa em diferentes proporções, de outro, visando aferir se alguma delas poderia adequar-se mais satisfatoriamente à melhoria das condições gerais do solo em questão.

Foram analisadas variações em propriedades químicas e físicas como retenção de cátions, efeito tampão, densidade aparente, condutividade hidráulica e porosidade.

Abre-se a possibilidade de os resultados deste projeto não se limitarem apenas à Indústria Mineral mas estenderem-se a outros setores onde haja a necessidade de recuperação de solos, fornecendo subsídios a eventuais modificações no manejo de solos agricultáveis, com perspectivas de geração de economia de recursos em irrigação, fertilizantes e defensivos agrícolas. 


\section{ABSTRACT}

The environmental recuperation of areas explored by sand mining in the Vale do Paraíba region, in the State of São Paulo, is a popular aspiration, a constitutional obligation and constitutes a differentiating factor in the visions of modern enterprise.

This work studies the utilization of peat as a soil conditioner in the final stage of the recuperation process for these areas: the revival of indigenous vegetation.

This idea arose from the author's experience in technological and mineral research into peat, coupled with the observation and monitoring of these environmentally sensitive areas, whose soils were, from an agricultural stance, generally unproductive. The utilization of peat, in these cases, represented the difference between success and the necessity for a replantation process.

This study presents a review of the agronomic properties of peat as well as the application of organic matter in the revegetation of damaged land. It is a comparative study between laboratory assay results from soil samples in their original state, and those where the soil has variable peat contents, seeking to ascertain which, if any, results in better general conditions for that particular soil.

Both physical and chemical properties were analyzed, with an emphasis on cation exchange capacity, buffering, bulk density, hydraulic conductivity and porosity.

There is a possibility that the results of this project can extended beyond the Mineral Industry to other sectors, where there are needs for soil recuperation, leading to cost savings for irrigation, fertilizers and agrotoxic compounds in food production areas. 


\section{INTRODUÇÃO}

A degradação ambiental, observada neste final de milênio, é tema de grande preocupação tendo-se em vista as condições para a sobrevivência e qualidade de vida das gerações futuras.

Exemplos de destacada degradação ambiental decorrem de processos erosivos, provenientes de empreendimentos modificadores do meio físico.

Os registros de grandes erosões, no Brasil e no mundo, estão diretamente associados ao desmatamento seguido de atividades colonizadoras, exploração agrícola, grandes obras civis, expansão de áreas urbanas e, de particular interesse à presente pesquisa, exploração mineral.

No caso específico da mineração, o desmatamento de áreas extensas expõe amplas parcelas de solo àqueles processos erosivos, caso não sejam adotadas medidas oportunas e criteriosas de preservação.

O reflexo destes processos pode-se fazer sentir, mais significativamente, quando estes empreendimentos se situam nas proximidades de áreas urbanizadas, não raro com situações de risco à comunidade, como ameaças a habitações e ao patrimônio público, além da deterioração dos recursos naturais solo e água.

Tal é o caso de parte da região do Vale do Paraíba, Estado de São Paulo, onde há décadas se explora areia, principalmente, para abastecer o mercado de construção civil da Região Metropolitana de São Paulo.

Algumas peculiaridades da atividade mineral específicas para esta substância, como a forte demanda, produção quase artesanal, baixos valores agregados, custo elevado de transporte e a conseqüente necessidade de as lavras situarem-se nas proximidades dos centros de consumo, conduziram não só a situações de grande incômodo para as populações vizinhas, mas ainda à notória incompatibilidade, nestes casos, entre atividade mineradora e preservação ambiental.

Pressões nacionais e internacionais para proteger o meio ambiente, especialmente as oriundas das normas ISO, fazem GRIFFITH et al. (1996) acreditarem que as empresas mineradoras brasileiras terão que assumir 
compromissos e investimentos maiores que os atuais para atenderem às exigências políticas e mercadológicas.

Sob esta ótica, nos dias atuais, o panorama se encontra em discreta modificação em função da rígida legislação ambiental existente, fazendo com que projetos do setor, outrora raramente conduzidos com o necessário suporte técnico, contemplem etapas de recuperação das áreas degradadas.

A turfa foi experimentalmente usada, como condicionador de solos, na recomposição florística de parte das margens do Rio Paraíba do Sul, para a recuperação ambiental de algumas áreas mineradas na extração de areia.

Sua utilização foi propiciada pela ocorrência, numa destas áreas, de um índice muito baixo (cerca de 5\%) de evolução das mudas introduzidas na fase final de recuperação - o restabelecimento da vegetação nativa. Sua eficácia ficou comprovada no replantio, quando, associada aos habituais calcário dolomítico e adubos, elevou aquele índice a níveis de $95 \%$. 


\section{OBJETIVOS}

Uma vez observado, na prática, os efeitos benéficos da utilização de turfa nos resultados de recuperação ambiental de áreas mineradas, constitui objetivo do presente trabalho o estudo das alterações promovidas, pela sua adição, nas propriedades de um solo que servirá de suporte ao restabelecimento de vegetação nativa, em área de extração de areia já exaurida e com plano de recuperação ambiental em implantação.

O objetivo foi perseguido através do cotejo entre resultados de ensaios laboratoriais físico-hídricos e químicos realizados para o solo em duas condições distintas: como testemunho (branco) e com adição de turfa.

Desta forma, foram consideradas no presente estudo algumas das principais propriedades de um solo no tocante à sua "produtividade agrissilvipastoril": densidade, porosidade, condutividade hidráulica, capacidade de troca de cátions e efeito tampão. 


\section{MOTIVAÇÃO E HIPÓTESES DE TRABALHO}

O interesse num trabalho desta natureza teve origem na experiência do autor como geólogo residente numa mina de turfa, minério que despontou, na década de 70, como potencial substituto do petróleo importado, cujo preço, submetido ao cartel dos produtores, se elevara muito.

A mina acima referida foi originalmente desenvolvida pela CESP, então Centrais Elétricas de São Paulo, para fornecer combustível a uma usina termelétrica projetada para geração de energia para o Sul e Sudeste do país.

Entretanto, a normalização e a estabilização dos preços mundiais do petróleo, aliadas a outros fatores impeditivos (pouca competitividade econômica perante os derivados do petróleo e outras fontes energéticas alternativas, pequenas reservas geológicas para este fim, impacto ambiental decorrente da queima do minério), conduziram à paralisação temporária das atividades de desenvolvimento antes mesmo do início das operações de extração.

Tendo em vista aplicações agrícolas da turfa tradicionalmente consagradas em muitos países, a mina passou a operar, sob nova administração, redirecionada a este enfoque, até então inédito no Brasil.

A despeito do descrédito e desconfiança iniciais do mercado nacional, o baixo índice de vendas dos primeiros anos de operação foi gradativamente revertido até atingir níveis de produção jamais imaginados no início do projeto.

A vizinhança a inúmeros empreendimentos de extração de areia, às voltas com projetos de recuperação ambiental de suas áreas lavradas nem sempre bem sucedidos no tocante ao restabelecimento da cobertura vegetal nativa, fez com que surgisse a idéia e as primeiras experiências de sua utilização como um melhorador dos solos degradados pela atividade extrativa.

Que levou este bem mineral, acreditado no Brasil apenas como insumo energético, a atuar como solo artificial, a promover um vigoroso desenvolvimento de sementes em estufas e a condicionar física e quimicamente solos agrícolas exauridos por anos sucessivos de cultivo, ou que não permitiam o crescimento regular de mudas para si transplantadas? 
O diferencial, representado pela sua utilização nestes casos, foi o elemento motivador do presente estudo.

Constitui hipótese de trabalho a comprovação de alterações benéficas a serem promovidas pela adição de turfa às amostras de solo, conforme sumarizadas na tabela 1.

Tab. 1 - possíveis alterações físicas e químicas em solos com a adição de turfa.

\begin{tabular}{lll}
\hline Efeitos Físicos & \multicolumn{1}{c}{ Efeitos Químicos } \\
\hline - diminuição dos valores de massa $\bullet$ & aumento na Capacidade de \\
específica aparente, acarretando uma & $\begin{array}{l}\text { Troca de Cátions (CTC); } \\
\text { atenuação na compactação; }\end{array}$ \\
- $\begin{array}{l}\text { redesenho do do espaço poroso, } \\
\text { acarretando melhoria das propriedades }\end{array}$ \\
hidráulicas (condutividade e porosidade).
\end{tabular}




\section{REVISÃO BIBLIOGRÁFICA}

\subsection{TURFA}

A turfa é uma substância fóssil, organo-mineral, originada da decomposição de restos vegetais, encontrada em áreas alagadiças como várzeas de rios, planícies costeiras e regiões lacustres. Segundo o INSTITUTO DE PESQUISAS TECNOLÓGICAS - IPT (1979), apresenta-se como um material "mineral"-orgânico, formado nos últimos 10.000 anos em antigos lagos rasos das regiões frias do Hemisfério Norte e nas áreas de inundação ou charcos, como no Brasil; resulta do atrofiamento e decomposição incompleta de material lenhoso e de arbustos, musgos e liquens em condições de excessiva umidade (até 95\%), além de materiais inorgânicos.

Segundo MARTINO \& KURTH (1982), apresenta cor variando do amarelo ao marrom escuro, dependendo do grau de deterioração biológica, desintegração mecânica das fibras e presença de sedimentos.

O processo de decomposição da matéria orgânica ocorre em condições ambientais anóxicas, sendo responsável pela sua evolução fóssil o desaparecimento da estrutura vegetal, a perda de oxigênio e o enriquecimento relativo em carbono (IPT, 1978). O ambiente saturado em água inibe a decomposição biológica ativa dos tecidos da planta e promove a retenção do carbono, que normalmente seria liberado na forma de produtos gasosos provenientes da atividade biológica (MARTINO \& KURTH, 1982).

A velocidade de decomposição depende, além do tipo de vegetação, do clima, que, se tropical, favorece uma grande disponibilidade de massa vegetal e promove uma decomposição acelerada, resultando na diminuição da quantidade de material a ser fossilizado como turfa. Gerações consecutivas de vegetais se transformam em turfa, provocando o empilhamento em camadas, cujas propriedades físico-químicas variam em função do tipo de vegetação original, do grau de decomposição da turfa (geralmente aumenta em direção à base do depósito) e da quantidade de matéria orgânica (LEMOS et al., 1981 e LENZ, 1984 apud GARCIA, 1994). 
A definição varia conforme a instituição e o país, mas é consensual aceitar-se como sendo um material contendo $25 \%$ ou menos de massa inorgânica, referível à base seca (ANDREJKO et al., 1983).

Segundo INTERNATIONAL PEAT SOCIETY - IPS (1997), mais de 90\% das turfeiras no mundo situam-se nos cinturões frios e temperados do Hemisfério Norte; o remanescente concentra-se em latitudes tropicais e subtropicais, em sua maioria em ambientes florestais.

De forma geral, estima-se que mais de 250 milhões de hectares $\left(2,5 \times 10^{6}\right.$ $\left.\mathrm{km}^{2}\right)$ da superfície terrestre sejam cobertos de turfa $(\sim 1,67 \%$ das terras emersas), ficando $85 \%$ desse total dentro de fronteiras da Rússia, Canadá e EUA (IPT, 1979).

Os mais extensos depósitos do mundo ocorrem onde a última glaciação, através de uma redução das áreas permanentemente geladas, produziu depressões topográficas ou lagos rasos, com chuvas abundantes e bem distribuídas e onde as baixas temperaturas retardaram a decomposição de plantas rasteiras e arbustivas.

Em função do material de origem, mas principalmente pelo grau de decomposição, a turfa varia em seu aspecto estrutural desde uma pasta gelatinosa preta (alto grau de decomposição, normalmente nas camadas mais profundas das jazidas) até uma condição fibrosa, de coloração marrom clara, de musgos, nos estratos mais superficiais.

Basicamente os depósitos de turfa têm-se formado de dois modos (IPT, 1979):

- pelo preenchimento das depressões de pequenos lagos e lagoas por matéria orgânica morta. O processo começa quando a vegetação das margens cresce em direção ao centro da depressão, constituindo uma camada de plantas aquáticas. A expansão desta esteira vegetal sobre as águas permite que outras plantas migrem para as porções mais estáveis das bordas do lago (figura 1); 


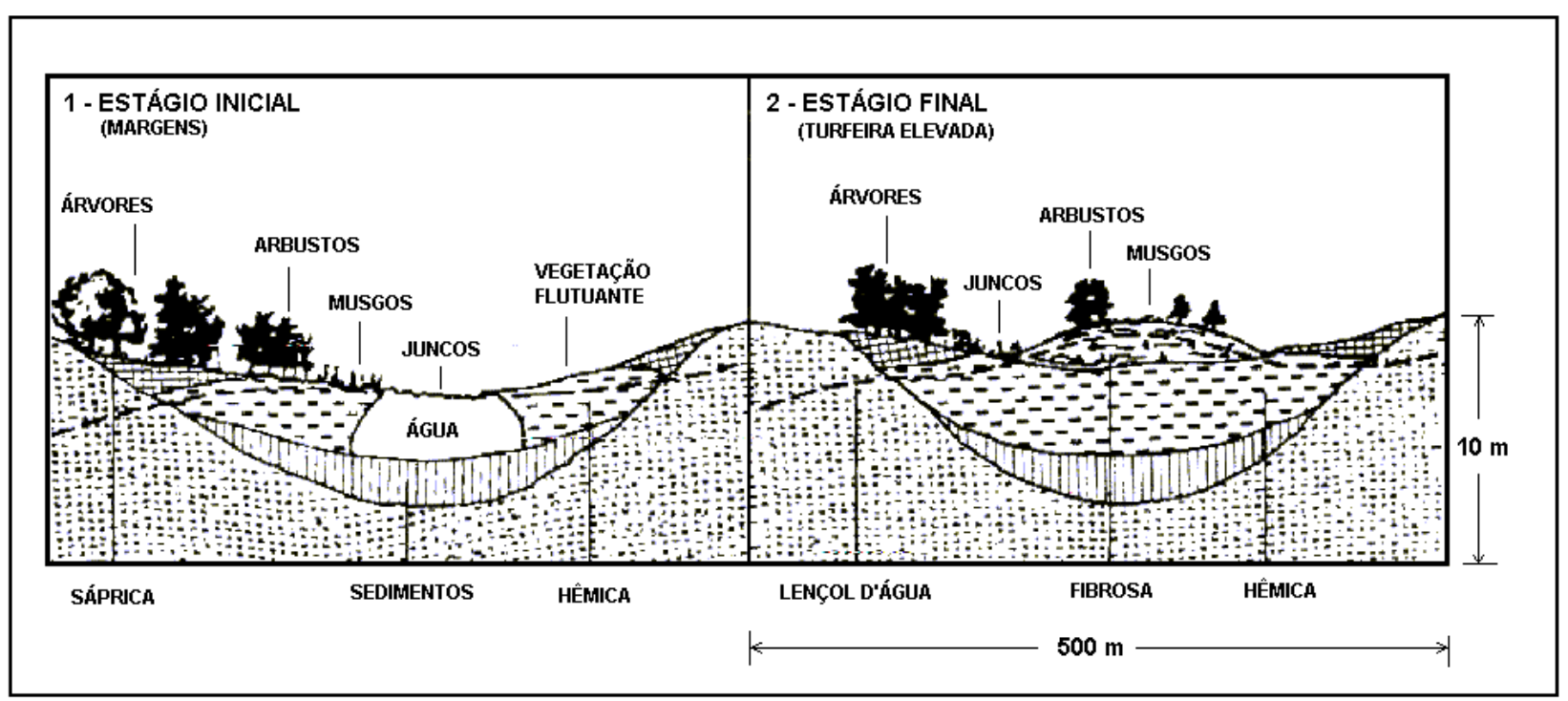

Fig. 1 - processo de formação de turfeiras em lagoas (IPT, 1979)

- pela inundação constante e formação de lagoas ribeirinhas em terras baixas de vales, ou estuários de rios, com o conseqüente acúmulo de plantas mortas, folhas, galhos, frutos silvestres, flores e outros. O espalhamento do ambiente saturado de água por áreas planas (charcos ou pântanos), com pouca drenagem, possibilita o início do processo de deposição em camadas de material vegetal orgânico. Esta formação inicial propicia a retenção das águas da inundação e das chuvas, permitindo o aparecimento de musgos (sphagnum moss). O posterior atrofiamento nas áreas ricas em musgos é lento, devido à sua alta acidez e grande capacidade de absorção d'água. $\mathrm{O}$ retardamento da decomposição da matéria morta, combinado com 0 crescimento vigoroso dos musgos, resulta em rápida acumulação da turfa de musgos em muitas áreas (figura 2). 


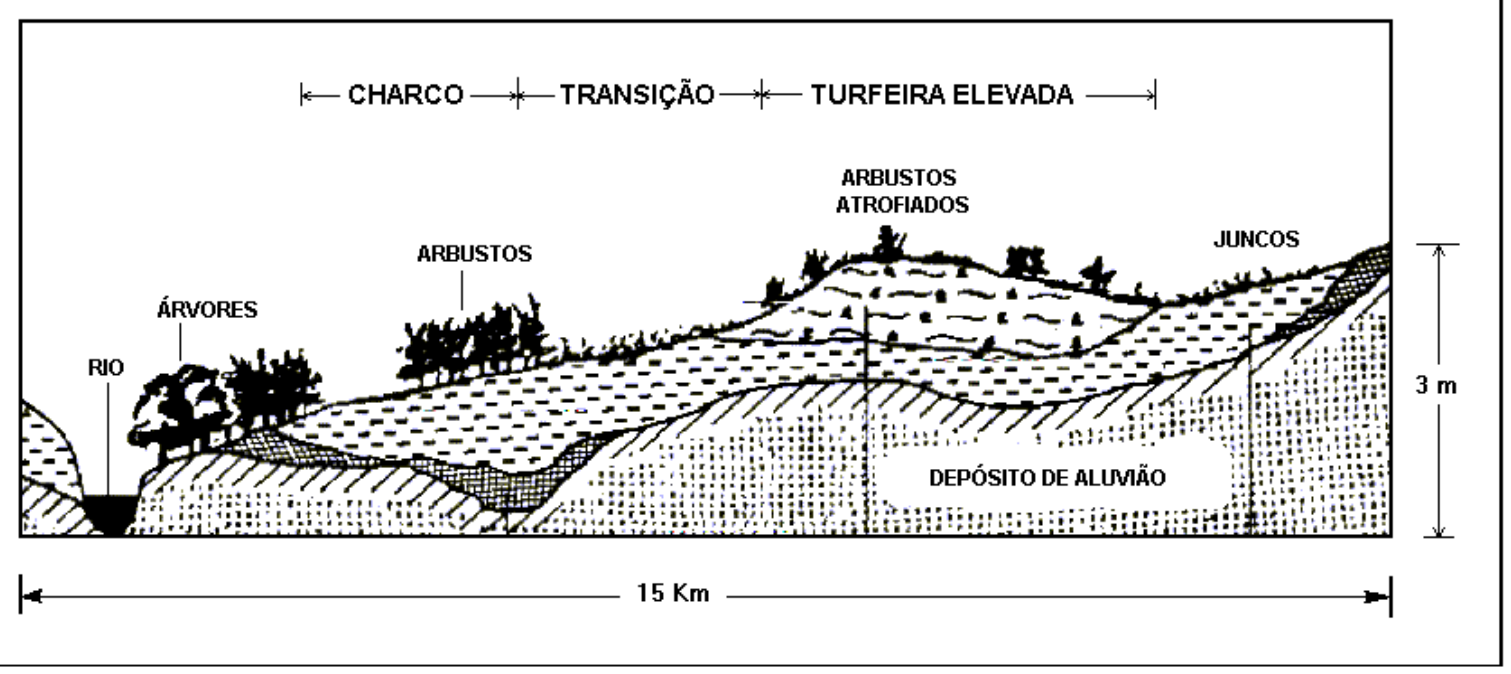

Fig. 2 - formação de turfeiras em áreas de inundação (IPT, 1979)

Segundo a IPS (1997), quanto mais quente o clima, mais rapidamente o material se decompõe. A taxa de acumulação é maior onde as temperaturas são elevadas o suficiente para permitirem um rápido crescimento vegetal e baixas o suficiente para impedirem atividade microbiológica muito intensa; tais condições são mais freqüentes no Hemisfério Norte.

Há várias classificações para turfas, bastante semelhantes entre si, que procuram ressaltar, basicamente, o seu grau de decomposição. As descrições mais freqüentemente utilizadas se referem ao modelo sueco, idealizado por Von Post (FUCHSMAN, 1980), em que a turfa é descrita numa escala visual após um teste expedito de se espremer uma amostra fresca e molhada na mão e observar o aspecto do material que flui entre os dedos e o que fica retido na mão (Quadro 1). A um valor H4, por exemplo, atribui-se um estado de decomposição de $40 \%$ ao material analisado. 
Quadro 1 - Classificação das turfas pelo o grau de humificação (escala visual de Von Post)

\begin{tabular}{|c|c|c|c|c|c|}
\hline \multirow{2}{*}{$\begin{array}{l}\text { GRAU DE } \\
\text { HUMIFI- } \\
\text { CAÇÃOO }\end{array}$} & \multirow[b]{2}{*}{$\begin{array}{l}\text { CARACTE- } \\
\text { RÍSTICAS }\end{array}$} & \multirow{2}{*}{$\begin{array}{c}\text { COR DA } \\
\text { ÁGUA QUE } \\
\text { FLUI ENTRE } \\
\text { OS DEDOS }\end{array}$} & \multirow{2}{*}{\begin{tabular}{|c|} 
FRAÇÃO DA \\
TURFA QUE FLUI \\
ENTRE OS \\
DEDOS
\end{tabular}} & \multicolumn{2}{|c|}{ RESTA NA MÃO } \\
\hline & & & & FORMA & $\begin{array}{l}\text { ESTRUTURA } \\
\text { VEGETAL }\end{array}$ \\
\hline $\mathrm{H} 1$ & $\begin{array}{c}\text { sem } \\
\text { decomposição }\end{array}$ & incolor & \multirow{4}{*}{$\begin{array}{l}\text { não passam } \\
\text { sólidos } \\
\text { entre os } \\
\text { dedos }\end{array}$} & \multirow{3}{*}{$\begin{array}{l}\text { Não tem } \\
\text { aspecto } \\
\text { gelatinoso }\end{array}$} & \multirow{4}{*}{$\begin{array}{l}\text { estrutura } \\
\text { vegetal } \\
\text { nitidamente } \\
\text { reconhecível }\end{array}$} \\
\hline $\mathrm{H} 2$ & $\begin{array}{l}\text { muito pouco } \\
\text { decomposta }\end{array}$ & $\begin{array}{l}\text { ligeiramente } \\
\text { castanha }\end{array}$ & & & \\
\hline $\mathrm{H} 3$ & $\begin{array}{l}\text { fracamente } \\
\text { decomposta }\end{array}$ & $\begin{array}{c}\text { castanha } \\
\text { fraca }\end{array}$ & & & \\
\hline $\mathrm{H} 4$ & $\begin{array}{l}\text { decomposta } \\
\text { fracamente }\end{array}$ & $\begin{array}{c}\text { muito } \\
\text { castanha }\end{array}$ & & \multirow{4}{*}{$\begin{array}{l}\text { Apresenta } \\
\text { aspecto } \\
\text { gelatinoso }\end{array}$} & \\
\hline $\mathrm{H} 5$ & decomposta & \multirow{6}{*}{$\begin{array}{l}\text { líquido } \\
\text { bem } \\
\text { escuro }\end{array}$} & $\begin{array}{l}\text { poucos sólidos } \\
\text { fluem }\end{array}$ & & $\begin{array}{l}\text { ainda poucos } \\
\text { restos vegetais }\end{array}$ \\
\hline $\mathrm{H} 6$ & $\begin{array}{c}\text { bem } \\
\text { decomposta }\end{array}$ & & $\begin{array}{c}\text { passa } 1 / 3 \text { do } \\
\text { volume }\end{array}$ & & reconhecíveis \\
\hline $\mathrm{H} 7$ & $\begin{array}{l}\text { fortemente } \\
\text { decomposta }\end{array}$ & & $\begin{array}{l}\text { passa metade do } \\
\text { volume }\end{array}$ & & $\begin{array}{l}\text { restos vegetais } \\
\text { muito pouco } \\
\text { reconhecíveis }\end{array}$ \\
\hline $\mathrm{H} 8$ & $\begin{array}{c}\text { muito } \\
\text { fortemente } \\
\text { decomposta }\end{array}$ & & $\begin{array}{l}\text { passa } 3 / 5 \text { do } \\
\text { volume }\end{array}$ & \multirow{2}{*}{\multicolumn{2}{|c|}{$\begin{array}{l}\text { ficam na mão resíduos de } \\
\text { fibras, raízes, etc. }\end{array}$}} \\
\hline $\mathrm{H} 9$ & $\begin{array}{c}\text { quase } \\
\text { integralmente } \\
\text { decomposta }\end{array}$ & & passa quase tudo & & \\
\hline $\mathrm{H} 10$ & $\begin{array}{c}\text { completamente } \\
\text { decomposta }\end{array}$ & & $\begin{array}{l}\text { flui integralmente } \\
\text { entre os dedos }\end{array}$ & \multicolumn{2}{|c|}{$\begin{array}{c}\text { sobra muito pouco ou quase } \\
\text { nada nas mãos }\end{array}$} \\
\hline
\end{tabular}

Apresentam-se, na tabela 2, as classificações mais usuais para a turfa, bem como as variações em suas principais propriedades conforme o grau de decomposição (IPT, 1979). Abaixo da tabela são apresentadas setas cujos sentidos indicam aumento no parâmetro considerado. 
Tab. 2 - sistemas de classificação de turfa

\begin{tabular}{|c|c|c|c|}
\hline Sist. Classif. & \multicolumn{3}{|c|}{ Grau de Humificação } \\
\hline U.S.D.A. ${ }^{(1)}$ & Fibrosa & Hêmica & Sáprica \\
\hline $\begin{array}{l}\text { Soviético }{ }^{(2)} \\
\text { Sueco }{ }^{(3)} \\
\text { I.P.S. }{ }^{(4)}\end{array}$ & $\begin{array}{c}10,20,30 \\
1,2,3 \\
\text { Leve }\end{array}$ & $\begin{array}{c}40,50,60 \\
4,5,6 \\
\text { Escura }\end{array}$ & $\begin{array}{c}70,80,90,100 \\
7,8,9,10 \\
\text { Preta }\end{array}$ \\
\hline $\begin{array}{c}\text { Característica } \\
\text { básica }\end{array}$ & $\begin{array}{l}>2 / 3 \text { fibras } \\
\text { reconhecíveis }\end{array}$ & $\begin{array}{l}1 / 3 \text { a } 2 / 3 \text { fibras } \\
\text { reconhecíveis }\end{array}$ & $\begin{array}{l}<1 / 3 \text { fibras } \\
\text { reconhecíveis }\end{array}$ \\
\hline
\end{tabular}

Teor em Fibras

M.E.A. ${ }^{(5)}$

$\mathrm{pH}$

PCS ${ }^{(6)}$

Carbono Total

Porosidade

Permeabilidade

S. S. ${ }^{(7)}$

Granulometria

Poder de sorção

Notas:

(1) U. S. Department of Agriculture and Agricultural Experiment Stations

(2) INSTORF (Instituto Soviético de Turfa)

(3) Von Post (Suécia)

(4) International Peat Society (I.P.S.)

(5) Massa Específica Aparente

(6) Poder Calorífico Superior

(7) Superfície Específica

Ainda segundo o IPT (1979), a I.P.S. assim classifica a turfa:

- turfa leve: é pouco decomposta, geralmente marrom-avermelhada, com a porção orgânica contendo mais de 2/3 de fibras vegetais reconhecíveis e o restante decomposto além do reconhecimento. É encontrada em ambiente ácido, formando as camadas mais superficiais das turfeiras (em geral, derivadas de musgos) tendo muito boa aceitação como substrato para formação de mudas; 
- turfa escura: representa um grau intermediário entre a turfa leve e a preta, com tonalidade entre o marrom e o preto, apresentando 1/3 a 2/3 de fibras reconhecíveis. Normalmente é formada por gramas, arbustos, plantas rasteiras silvestres e plantas aquáticas;

- turfa preta: é bastante escura, contendo menos de $1 / 3$ de fibras reconhecíveis, podendo apresentar forma gelatinosa. Algumas vezes se forma a partir da acentuada decomposição dos dois outros tipos; em outras, o processo de formação se dá a partir da sedimentação, no fundo de lagos rasos, de material orgânico morto de plantas aquáticas e algas (sapropelito). Apresenta teor bastante elevado em húmus.

Pode-se estabelecer uma correspondência entre os tipos leve, escura e preta da I.P.S. com os tipos fibrosa, hêmica e sáprica da U.S.D.A.

Do ponto de vista físico-químico, a turfa é um material poroso e altamente polar, de elevada capacidade de adsorção para metais de transição e moléculas orgânicas polares (COUPAL \& LALANCETE, 1976).

Segundo COUILLARD (1994), estudos microscópicos revelam que seus litotipos apenas parcialmente decompostos (fibrosos) apresentam porosidade de aproximadamente $95 \%$ e área específica de até $200 \mathrm{~m}^{2} / \mathrm{g}$. Quimicamente, é um material complexo, apresentando lignina e celulose como constituintes maiores. O teor em substâncias húmicas é função direta do grau de decomposição.

FUCHSMAN (1980) identifica 4 grupos constituintes básicos em turfas, classificáveis de acordo com o modo com que podem ser processadas quimicamente:

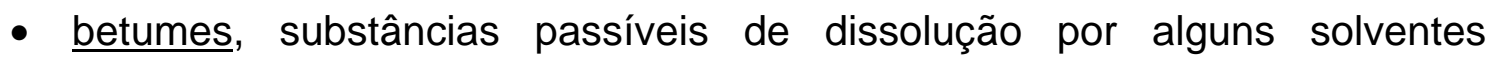
orgânicos, compreendendo ácidos graxos, ceras e esteróides;

- $\quad$ ácidos húmicos, substâncias solúveis em meio aquoso alcalino;

- carboidratos, como celulose e proteínas, substâncias passíveis de dissolução em meio ácido; e

- ligninas, substâncias fenólicas solúveis em bases fortes que, na maioria das plantas, atua como um "cimento" nas fibras celulósicas, conferindo estabilidade estrutural a folhas, caules e raízes. 
As substâncias húmicas - produtos intermediários no ciclo de decomposição da matéria orgânica, originados da ação da microvida existente no solo (oxidação biológica) - consistem numa série de compostos de coloração amarela a preta, de alto peso molecular. Segundo PETRONI (1999), podem ser caracterizadas como ricas em grupos funcionais oxigenados tais como $\mathrm{COOH}, \mathrm{OH}$ fenólico e/ou enólico, $\mathrm{OH}$ alcoólico e $\mathrm{C}=\mathrm{O}$ de quinonas.

TAN (1993) afirma serem conhecidas também como humus e que o termo ácido húmico foi originado de BERZELIUS em 1830, que classificou a fração húmica dos solos em:

- ácidos húmicos - fração solúvel em meio alcalino;

- ácidos crênicos e apocrênicos - fração solúvel em água;

- huminas - fração insolúvel e inerte.

Segundo o mesmo autor, ODEN, em 1912, propôs a utilização do termo ácido fúlvico em substituição aos termos crênico e apocrênico.

Ainda segundo TAN (1993), as substâncias húmicas podem ocorrer também em rios, lagos, oceanos e em seus sedimentos; foram também relatadas em linhitos ou leonarditos, carvões e outros depósitos geológicos comercialmente explorados como fonte de humatos, utilizados como corretivos de solos.

Segundo FUCHSMAN (1980), as plantas vivas, das quais a turfa se origina, contêm principalmente proteínas, carboidratos, lipídeos e substâncias polifenólicas. Adicionalmente, pequenas quantidades de ácidos nucleicos, pigmentos, alcalóides e outras substâncias orgânicas estão presentes, além de compostos inorgânicos. De acordo com este autor, o processo de decomposição transcorre como descrito a seguir.

As proteínas são as primeiras a serem decompostas; pequena porcentagem do nitrogênio das proteínas pode ser preservado e conferir pequenos teores à turfa. Segue-se a celulose, que compreende a maior fração dos carboidratos das plantas.

Os lipídeos constituem um grupo quimicamente heterogêneo que inclui gorduras e óleos (triglicérides), ácidos graxos livres, ceras (ésteres não 
glicéricos, álcoois e ácidos de cadeia longa, hidrocarbonetos e cetonas), esteróides e terpenos.

Durante a decomposição, os triglicérides prontamente hidrolisam para ácidos graxos e glicerol (este é prontamente consumido pelos microorganismos como fonte de carbono e oxigênio). Os ácidos graxos residuais, ceras e esteróides persistem na turfa como substâncias relativamente estáveis, coletivamente designadas como betumes.

As ligninas, compostos fenólicos de alto peso molecular, são relativamente estáveis à decomposição, embora sejam facilmente decomponíveis em condições aeróbias, como as predominantes nas regiões tropicais. Pelos procedimentos convencionais de classificação dos componentes da turfa, as ligninas são freqüentemente agrupadas com os quimicamente designados "ácidos húmicos". Ambas são substâncias de caráter polifenólico.

Os ácidos húmicos, a maior fração dos constituintes da turfa, não ocorrem nas plantas vivas e sua origem é matéria um tanto controversa. São considerados como originários diretamente de ligninas mas, diferentemente destas, têm alto teor de ácidos carboxílicos e significantes quantidades de nitrogênio.

Observa-se na figura 3 (STEVENSON, 1994) a estrutura hipotética do ácido húmico, mostrando os grupos $\mathrm{OH}$ fenólicos ligados e livres, quinonas, nitrogênio, oxigênio e grupos $\mathrm{COOH}$ distribuídos nos anéis aromáticos.

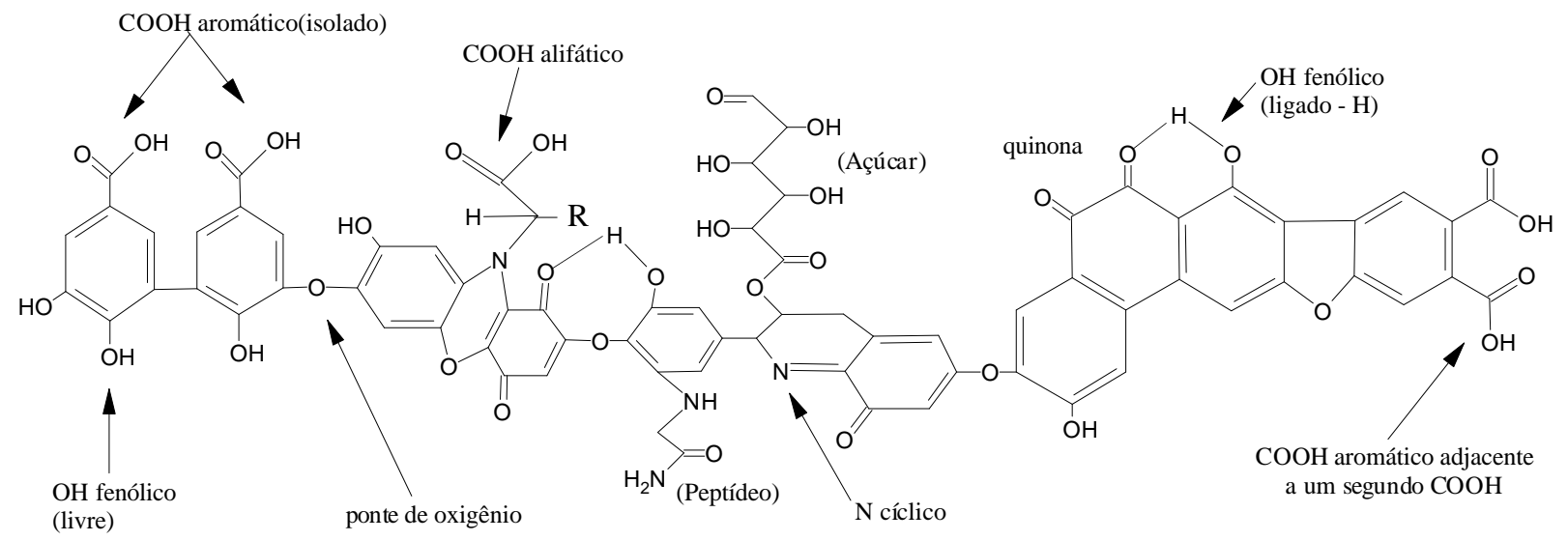

Fig. 3 - estrutura hipotética do ácido húmico (STEVENSON, 1994 modificada por PETRONI, 1999) 


\subsection{PropRiedAdes AGRONÔMICAS CONFERIDAS PELO USO DE HÚMUS}

Muitos povos, há pelo menos 2.000 anos, utilizam a turfa para fins energéticos; em regiões carentes de outros combustíveis fósseis é aproveitada para a geração de energias elétrica, térmica, industrial e doméstica (GARCIA, 1994). Grandes consumidores para estes fins são países frios onde ela ocorre de forma abundante, como Finlândia, Irlanda e Rússia, detendo este último cerca do $60 \%$ das reservas mundiais conhecidas.

Entretanto, embora seja mundialmente conhecida como um bem mineral energético, SUSZCZYNSKI (1982), num trabalho em que enfatiza eminentemente sua utilização como combustível fóssil, ressalta que "nem toda turfeira tem propriedades adequadas ao uso energético preponderante, mas toda turfeira tem propriedades implícitas de turfa agrícola", em função de seu elevado teor em matéria orgânica na forma de húmus.

Países como Alemanha e Holanda destinam, por lei, sua utilização exclusivamente para finalidades agrícolas (LOPEZ, 1985). EUA e Canadá são os países que mais extensivamente a utilizam na agricultura como condicionador de solos (IPT, 1978).

Segundo HENIS (1983), é o húmus que mais contribui para as propriedades físicas e químicas do solo, responsáveis pelo aumento nas colheitas. Atua como um condicionador de solos e como um fator de armazenagem de nutrientes.

É um material aglutinador de grumos, residindo aí um dos principais efeitos benéficos no condicionamento de solos. Segundo KIEHL (1985), grande parte dos constituintes da turfa consistem de partículas coloidais, capazes de formar emulsões com a água, ficando em suspensão em movimento browniano contínuo. Assim, misturada à água de chuva, distribui-se por ampla região; à medida que o solo vai perdendo água, as micelas coloidais se depositam nas suas partículas, agrumando-o e conferindo-Ihe características favoráveis.

Segundo MASCHIO et al. (1992), a matéria orgânica humificada atua como agente quelante, desfavorecendo a manutenção de íons metálicos em solução e promovendo a mitigação de sua toxidade para o solo, assim como a capacidade de intercâmbio iônico e a retenção de água. 
Segundo DEDECEK (1992), a diminuição do teor de matéria orgânica dos solos causa mudanças em várias de suas propriedades físicas, como estrutura, densidade, taxa de infiltração, teor de água disponível e estabilidade temporal dos agregados. Estas propriedades são tão interrelacionadas, que dificilmente se pode isolar o efeito sobre apenas uma delas.

PRIMAVESI (1984) define como bioestrutura o sistema de grumos e poros existentes em solos tropicais em sua camada mais superficial $(0$ a $20 \mathrm{~cm}$ de profundidade), estável à ação das águas de chuva, formado por agregados floculados pela presença de óxidos de ferro e alumínio e pela ação da microvida em presença de matéria orgânica.

O trabalho desta autora é referência na literatura nacional sobre a influência da matéria orgânica na estrutura e fertilidade de solos tropicais. Segundo ela, os constituintes argilosos do solo são ligados pela matéria orgânica em decomposição - húmus -, que desempenha, assim, uma ação aglutinadora de partículas.

Desta forma, uma vez decomposto o húmus pela ação de bactérias aeróbias, quebram-se as ligações orgânicas entre as partículas do solo e, por conseguinte, decai a estrutura biológica pelo colapso dos agregados maiores. A perda de húmus é, pois, a perda da bioestrutura e, com isto, a perda de grande parcela da produtividade do solo.

Em contrapartida, um solo grumoso é poroso e permite a pronta infiltração de água e de ar, além da penetração das raízes. Criou-se, com isso, a expressão "fertilidade física" para os solos tropicais em contraposição à fertilidade química, incapaz de, isoladamente, fazer o solo produzir.

PRIMAVESI (1984) afirma que, de modo geral, os solos de países de clima tropical não são tão férteis quanto aqueles existentes em países de clima temperado, em função da maior lixiviação de seus constituintes e deterioração de matéria orgânica a que estão sujeitos.

Por outro lado, em clima temperado a maior parte da matéria orgânica encontra-se na forma humificada, devido à lentidão dos processos de decomposição nessas regiões tendo em vista as temperaturas mais baixas.

Assim, relativamente aos de regiões temperadas, os solos nas regiões tropicais apresentam como desvantagens principais um maior grau de 
intemperismo, maior susceptibilidade à erosão, maior acidez (o que permite, com $\mathrm{pH}<5,6$, a presença de alumínio na forma solúvel, fitotóxico nesta condição) além de valores menores de C.T.C., C.R.A. (Capacidade de Retenção de Água) e matéria orgânica.

No entanto, tais solos, quando virgens ou nativos, apresentam uma bioestrutura extremamente favorável à produtividade, tendo em vista não terem sido ainda expostos a qualquer tipo de manejo ou intervenção, que normalmente conduzem, através do desmatamento, à maior exposição aos efeitos erosivos de chuvas torrenciais, diminuição dos teores em matéria orgânica, ruptura dos agregados e adensamentos.

PRIMAVESI (1984) atribui à bioestrutura as seguintes características dos solos tropicais:

- porosidade e permeabilidade, o que Ihes permite acumular águas de chuva;

- valores baixos de massa específica aparente (MEA) em função da inexistência ou inexpressividade de adensamentos e, com isto, maior possibilidade de enraizamento, permitindo às plantas explorar volume maior de solo em busca de água e nutrientes;

- arejamento e, portanto, disponibilidade de $\mathrm{O}_{2}$ a uma respiração oxidativa, processo pelo qual a planta produz mais energia, a ser utilizada na síntese de substâncias de crescimento, por mol de glicose proveniente da fotossíntese. Em solos menos arejados, a respiração pode vir a ser fermentativa, onde a produção de energia é cerca de 30 vezes menor que no processo oxidativo. Com menor produção de energia, o vegetal respira aceleradamente para produzir mais energia, aumentando o consumo de glicose. Neste ciclo vicioso, o desenvolvimento vegetal é reduzido, pois o seu metabolismo necessita de energia; todos os processos de síntese tornam-se lentos, chegando raramente à formação de proteínas e carboidratos mais complexos, permanecendo na planta muitos aminoácidos livres. A continuidade do processo pode levar a planta a consumir sua própria substância (as proteínas), perder sua turgescência e murchar irreversivelmente. 
Ainda segundo PRIMAVESI (1984), a matéria orgânica contribui, também, para o aumento da biodiversidade (micro, meso e macrofauna edáficas) pela manutenção dos mecanismos de autocontrole das espécies, com 0 conseqüente aumento na pressão interespécies - várias espécies com poucos exemplares - inibindo a possibilidade de estabelecimento de condições de exceção (proliferação de algumas espécies, em detrimento de outras, que podem conduzir ao aparecimento de pragas ou doenças).

O teor adequado em húmus também induz, segundo a mesma autora, o aumento do poder tampão dos solos, isto é, a resistência contra modificações bruscas de $\mathrm{pH}$ no meio, evitando choques violentos e desequilíbrios minerais provocados por calagem ou adubação sobre a microvida.

Solos que foram privados de sua cobertura vegetal, como os encontrados em áreas degradadas, perdem sua bioestrutura pela destruição dos grumos devido ao impacto das águas de chuva, com conseqüente compactação da superfície. De acordo com WÜNSCHE \& DENARDIN (1980 apud MONEGAT, 1992), o impacto direto das gotas de chuva é responsável por 95\% da erosão hídrica, sendo que o encrostamento formado na superfície apresenta efeitos maiores na absorção de água do que o tipo de solo ou a declividade do terreno. Instalam-se, em decorrência, erosão, assoreamento dos cursos d'água e inundações.

Em resumo, a melhoria das condições gerais do solo dá-se pelo fornecimento, por parte da matéria orgânica, de:

- substâncias aglutinantes ao solo, o que o torna grumoso, com bioestrutura estável à ação das chuvas, com um possível redesenho do espaço poroso no sentido do aumento da macroporosidade;

- alimento aos microorganismos ativos na decomposição, que produzem antibióticos que protegem as plantas de pestes, contribuindo à sanidade vegetal;

- aumento na biodiversidade;

- aumento da C.T.C., que é o lastro de fertilidade de um solo;

- aumento do efeito tampão;

- aumento de fenóis, que contribuem à respiração vegetal e sanidade radicular; 
- complexos químicos formados com os constituintes dos fertilizantes, em especial com o fósforo, protegendo-os de reações químicas indesejáveis com os óxidos e hidróxidos de Fe e Al existentes no solo, além de evitar suas perdas por lixiviação;

- aumento na C.R.A., contribuindo para a manutenção de uma umidade razoável no solo e possibilitando à planta atravessar períodos prolongados de estiagem.

Em vista da rápida decomposição da matéria orgânica em clima tropical úmido, sua reposição periódica é indispensável.

\subsection{RECUPERAÇÃO DE ÁREAS DEGRADADAS}

A recuperação de áreas degradadas, atividade relativamente recente no Brasil, é tema de amplo estudo. Segundo MASCHIO et al. (1992), tem despertado interesse de várias categorias de profissionais, encontrando maior afinidade nas áreas de Engenharia Florestal, Engenharia Agronômica, Geologia e Biologia. Transcende, contudo, os conhecimentos destas áreas e requer múlti e interdisciplinaridade.

É farta a bibliografia existente acerca de áreas degradadas no país. Em recente compilação sobre o assunto, o CONSELHO NACIONAL DA RESERVA DA BIOSFERA DA MATA ATLÂNTICA (1997) catalogou 609 trabalhos publicados em congressos, simpósios, reuniões técnicas e sob a forma de teses e dissertações, relatórios e projetos de pesquisa. Estes trabalhos abordam como causas principais da degradação a mineração, a agropecuária, a construção de hidrelétricas, a poluição, as unidades de conservação, as estradas, dentre outros.

Segundo CARPANEZZI et al. (1990 apud JESUS, 1994) um ecossistema degradado é aquele que, após distúrbios, teve eliminados, juntamente com a vegetação, os seus meios de regeneração bióticos, como o banco de sementes, banco de plântulas, chuvas de sementes e rebrota. Apresenta, portanto, baixa resiliência, isto é, seu retorno ao estado anterior pré-distúrbio 
pode não ocorrer ou ser extremamente lento. Já o ecossistema perturbado é aquele que sofreu distúrbios mas manteve os meios de regeneração bióticos: a ação humana não é obrigatória mas auxilia na sua recuperação, sendo possível à natureza encarregar-se do restante da tarefa. Nos degradados, a ação antrópica para a recuperação é necessária, pois eles já não dispõem daqueles eficientes mecanismos de regeneração.

MUNSHOWER (1994) aponta quatro termos utilizados com freqüência crescente no campo de revegetação de áreas degradadas: recuperação, restauração, reabilitação e revegetação. Embora alguma confusão seja estabelecida no seu uso, refletem conceitos bastante distintos:

- recuperação: é tornar um sítio degradado novamente aproveitável para uma determinada função, ou seja, a reconstituição topográfica do solo e da comunidade de plantas não serão iguais à condição original prédegradação; para uma área minerada é mais apropriado falar-se em recuperação (KAGEYAMA et al., 1997);

- restauração: consiste no retorno de um sítio degradado à sua condição original anterior à degradação, ou seja, é a reconstituição do ecossistema, com sua forma e função originais. A restauração inclui a recuperação (KAGEYAMA et al., 1997);

- reabilitação: ocorre sem a interveniência do homem quando é fornecido tempo suficiente para que as mudanças edáficas e biológicas ocorram. Estas mudanças são controladas pelo tipo de material existente na zona das raízes no início de processo de estabilização, pelo regime climático da área e pela disseminação acidental dos propágulos de plantas; e

- revegetação ("revegetation"): é o componente final e o mais visível no plano de recuperação.

Relativamente ao desgate parcial ou total, reversível ou irreversível, do ecossistema local atingido pelo distúrbio (irreversível aqui significando tempo e/ou investimentos inviáveis em termos práticos), MASCHIO et al. (1992) convencionaram os seguintes conceitos:

- perturbação: desgaste parcial e reversível;

- descaracterização: desgaste total e reversível; 
- depauperação: desgaste parcial e irreversível;

- degradação: desgaste total e irreversível.

SÁNCHEZ (1995) afirma ser generalizado no Brasil o emprego da frase "recuperar uma área degradada" no sentido de conferir-lhe um uso produtivo, que pode não ser o mesmo que o da situação anterior, pré-degradação. Este critério implica uma condição de equilíbrio dinâmico com o seu entorno.

Três aspectos distintos concorrem para o estabelecimento deste equilíbrio:

- sob um ponto de vista físico, a área deverá estar isenta de processos erosivos significativos e apresentar uma situação de estabilidade geotécnica onde não haja riscos de escorregamentos de taludes ou outros movimentos de massa;

- sob um ponto de vista químico, determinados materiais, minérios e rochas encaixantes, ou ainda insumos e substâncias utilizadas no empreendimento e, de alguma forma, incorporados à área, não devem apresentar potencial de contaminação de solo e de águas superficiais ou subterrâneas;

- sob um ponto de vista biológico, é necessário que a área recuperada mostre condições de ser auto-sustentável, ou seja, capaz de manter um rendimento equivalente àquele encontrado em áreas semelhantes, na mesma região (toma-se como exemplo a utilização agrícola como uso futuro da área recuperada).

De acordo com LUCHESI et al. (1992), a degradação do solo é definida pela FAO-UNEP como o resultado de um ou mais processos que minimizem sua capacidade produtiva, atual ou potencial, em produzir bens ou serviços.

MIELNICZUK \& SCHNEIDER (1984 apud LUCHESI et al., 1992), definem a degradação física do solo como uma mudança em suas propriedades físicas que influi negativamente sobre a produção; manifesta-se pela acentuada perda de qualidade na estrutura dos solos pelo colapso dos primeiros 3 a $4 \mathrm{~cm}$ devido ao efeito das chuvas, o que se traduz no aparecimento de finas crostas em sua superfície, na compactação sob a camada arável e na conseqüente diminuição nas taxas de infiltração de água, aumento do escoamento superficial, perdas 
por erosão, aumento nos custos de produção por unidade de área e redução da produtividade.

PRIMAVESI (1984) explica que o processo tem início com a desintegração dos grumos do solo pelo impacto das águas de chuva. As partículas dos grumos são lançadas à distância e os constituintes mais finos penetram com a água para dentro do solo. Estes constituintes mais finos depositam-se a uma certa profundidade (normalmente entre 30 e $40 \mathrm{~cm}$ ), preenchendo interstícios e dando início a um adensamento, conforme esquematizado na figura 4.

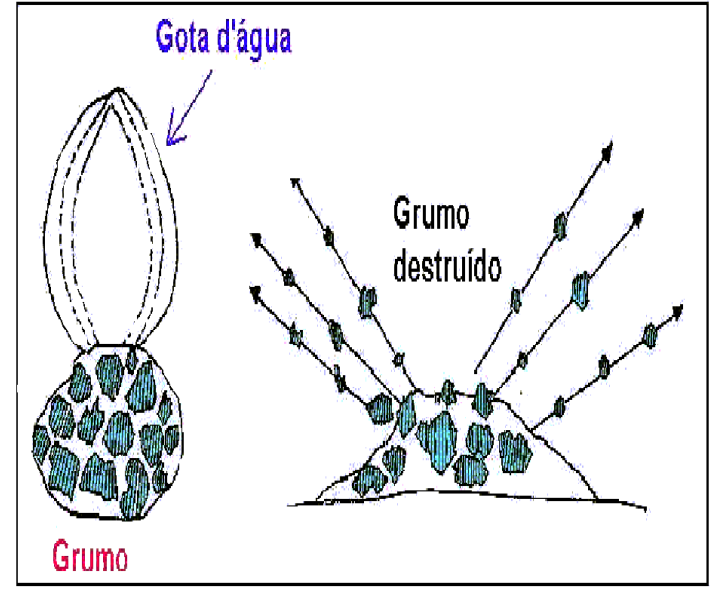

(a)

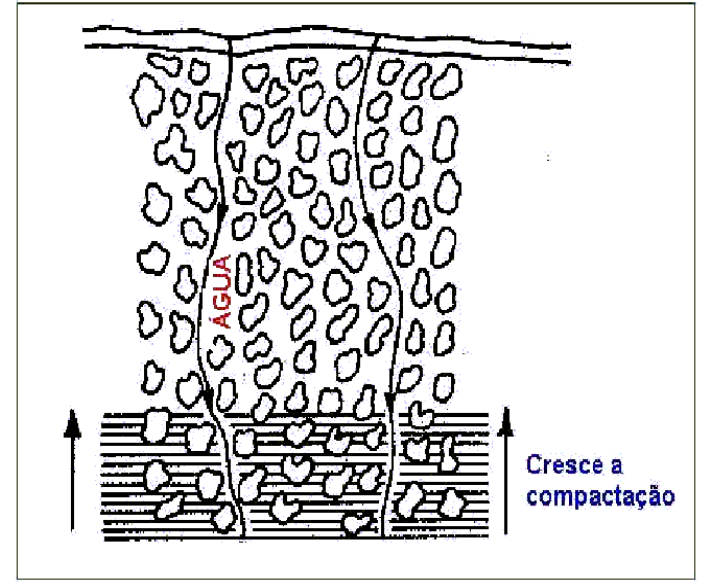

(b)

Fig. 4 - (a) efeito do impacto de uma gota de água sobre um grumo de solo; (b) formação do adensamento pela sedimentação de argila carreada pela água de infiltração (mod. de PRIMAVESI, 1984).

De acordo com PALADINI \& MIELNICZUK (1991 apud BONI et al., 1994), é reconhecida a tendência generalizada de os sistemas de manejo agrícolas usuais provocarem a redução da porosidade total (aumento na microporosidade e na densidade do solo e diminuição da macroporosidade), especialmente com o revolvimento intensivo do solo, aliado, principalmente, a baixas taxas de incorporação de resíduos orgânicos. A associação destes a fatores naturais, como clima e relevo, pode desencadear processos erosivos de grande expressão.

SÃO PAULO (1990) define a erosão como um balanço entre processos naturais de formação do solo (alteração de rocha e pedogênese) e processos 
envolvendo sua remoção (por agentes como a água das chuvas, por exemplo), cujo equilíbrio é deslocado no sentido destes últimos.

A erosão pode ser considerada normal quando inserida num quadro que reflita certos equilíbrios naturais; entretanto, quando intensificada, ultrapassa em velocidade os processos de formação dos solos, não permitindo que estes se regenerem. Dependendo da intensidade, pode-se atingir a perda de diversas camadas ou horizontes, até que aflorem as rochas subjacentes.

A perda total do solo constitui índice total de degradação de uma região, impedindo a realização de importantes atividades humanas.

Ainda segundo SÃO PAULO (1990), o impacto da erosão manifesta-se através do assoreamento da rede de drenagem local pelo aumento da carga sedimentar em suspensão, o que pode ocasionar, dependendo da extensão do processo, diminuição da capacidade armazenadora de reservatórios para abastecimento público ou geração de energia, corrosão de turbinas em hidrelétricas, além de enchentes trágicas. São também possíveis as alterações ecológicas que afetem fauna e flora, como o soterramento de comunidades bentônicas e o prejuízo a plantas que têm sua capacidade fotossintética alterada pela redução da luminosidade provocada pelo material em suspensão. Segundo CANIL \& RIDENTE Jr. (1997), se a carga sedimentar em excesso comprometer também a rede de esgotos, com entupimento de galerias, aos efeitos perniciosos das cheias deve-se acrescer, também, a degradação das condições sanitárias pela dispersão de poluentes na rede de drenagem.

Segundo o IPT (1995 apud OGURA et al., 1997), estima-se, para o Estado de São Paulo, uma perda anual de 200 milhões de toneladas de solo; e, também, que menos de $10 \%$ do total de suas áreas agricultáveis apresentem bom estado de conservação.

Supondo-se que a perda anual restrinja-se ao primeiro centímetro superficial e tomando-se como referência uma densidade média de $1,0 \mathrm{~g} / \mathrm{cm}^{3}$ para o solo, ter-se-á uma perda de 100t/ha/ano. Outros estudos apontam valores mais conservadores: para LAL et al. (1989 apud BITAR, 1997) a perda anual, para países como Brasil, Argentina e Paraguai, situar-se-ia em 18,8t/ha. Vários cientistas sugerem que, sob condições naturais, o solo é formado a uma taxa de $2,5 \mathrm{~cm}$ num período compreendido entre 300 e 1000 anos (PIMENTAL 
et al., 1976 apud DEDECEK, 1992) e, portanto, sob tal ótica, deve ser considerado um recurso não renovável.

Em termos globais, a FAO - Food and Agriculture Organization, agência da ONU para a agricultura e alimentação - estima em 29\% da superfície terrestre a área com solos degradados pela erosão e que 6 a 7 milhões de hectares se tornam improdutivos anualmente devido a este problema (CANIL \& RIDENTE Jr, 1997).

Vários são os setores econômicos que geram significativa degradação ambiental. Segundo MASCHIO et al. (1992), as pesquisas acadêmicas conduzidas no país sobre áreas degradadas limitam-se, normalmente, à causa e extensão do processo degradante, priorizando-se as atividades de mineração (29\%) e agricultura (21\%). É interessante observar, entretanto, que as obras civis e a agricultura movimentam, respectivamente, 6 vezes e 100 vezes maior volume de material do que a mineração (MINEROPAR, 1991 apud MASCHIO et al., 1992).

O solo é um dos elementos da paisagem mais diretamente afetados pela atividade mineradora. Segundo PRIMAVESI (1984), como elemento de suporte a toda atividade antrópica, o solo não é imutável nem estático: pela modificação deste único fator do complexo ecológico - o solo -, modificam-se automaticamente todos os demais fatores (vegetação, clima, relevo, biota), a fim de formar um novo equilíbrio abarcando também o fator modificado. A correta compreensão deste fato pode permitir manejar estes fatores à vontade; entretanto, intervenções inconscientes ou irracionais acarretam, igualmente, modificações tendentes àquele equilíbrio, o que acaba ocorrendo, na maior parte dos casos, de modo catastrófico e fora de controle.

No caso específico da mineração, há a necessidade de recuperar-se 0 terreno onde ocorreu a exploração. A simples recolocação do material originalmente chamado "solo" (quando estocado em lugar específico, prevendo reutilização) não garante a volta das condições de vida vegetal e animal ao lugar, principalmente se longo intervalo de tempo decorreu entre sua retirada e retorno, como normalmente sói acontecer.

A mineração é uma atividade econômica que, por sua própria natureza, implica modificação das condições ambientais originais de determinada região, 
principalmente quando se considera que seus efeitos podem extrapolar os limites geográficos da área de extração. Isto contribuiu decisivamente para a formação do preconceito de ser a mineração, em que pese seu caráter de utilidade pública, a atividade econômica que mais degrada o meio ambiente.

Em decorrência, com a Constituição Brasileira de 1988 surge o caráter de obrigatoriedade da recuperação das áreas degradadas pela mineração; de fato, ela estabelece que "aquele que explorar recursos minerais fica obrigado a recuperar o meio ambiente degradado, de acordo com solução técnica exigida pelo órgão público competente, na forma da lei” (§ $2^{\circ}$ do art. 225).

Embora historicamente reconhecida como atividade de elevado impacto ao meio ambiente, a mineração se tornou um dos setores que mais contribuíram para o aperfeiçoamento das tecnologias de recuperação de áreas degradadas.

Dentro deste contexto inserem-se os objetivos da presente pesquisa: estabelecer em que níveis a turfa pode atuar como um melhorador das características dos solos, fazendo com que tais terrenos voltem a ter condições de suportar vegetação, uma vez que perderam suas características originais de fertilidade. Não podem mais ser consideradas como "solos", passíveis de abrigar vida vegetal, as áreas decapeadas, contaminadas, submetidas a intenso tráfego de máquinas, mineradas ou destinadas a receber rejeitos e/ou estéreis das operações de uma mina.

Segundo BRASIL (1990), os procedimentos habitualmente necessários à recuperação de áreas mineradas compreendem, simplificadamente, respeitadas as peculiaridades de cada caso:

1. preenchimento da área lavrada com estéril e/ou rejeito. Cuidados especiais devem ser tomados quanto à contaminação do lençol freático se os materiais contiverem substâncias tóxicas;

2. regularização do terreno, ou seja, o preparo do relevo para receber a vegetação. A nova conformação topográfica deve atender à estabilidade do solo e taludes, controle da erosão e apresentar alguma semelhança com o relevo original;

3. tratamento da superfície final, envolvendo - sem se limitar a isto: 
- recolocação do "topsoil" (raramente preservado no passado quando do decapeamento da jazida);

- terraços em camalhões (em locais com declividade menor que $20 \%$ ) ou em bancadas ou patamares (para declividades superiores a $20 \%$ );

- construção do sistema final de drenagem (canais e valetas), que deve ser implementado o mais rápido possível. Em áreas com altas declividades deverão ser preferivelmente revestidos (sacos com solocimento, argamassas com pedras de mão, etc.); em alguns casos a construção de canais em escadas é recomendável para a dissipação da energia das águas;

- redução do grau de compactação do solo, que deverá apresentar-se com densidade entre 1,4 a $1,6 \mathrm{~g} / \mathrm{cm}^{3}$. Nas operações de escarificação e subsolagem, deve ser evitada a inversão das camadas do solo, principalmente após a colocação do "topsoil";

- correção da fertilidade, com incorporação de matéria orgânica, adubação verde e química (macro e micronutrientes);

4. revegetação;

5. manutenção.

\subsection{REVEGETAÇÃO}

BRASIL (1990) ressalta que a revegetação "é a prática principal para se obter a formação de um novo solo, controlar a erosão, evitar a poluição das águas e, se for escolhida a manutenção da vida selvagem como uso futuro do solo, promover o retorno desta vida." Em empreendimentos de mineração, é executada em locais onde não mais existe solo com características agrícolas, ou seja, em depósitos de rejeito/estéril, nos "pits" escavados, taludes, etc.

Há um forte desejo de ver-se a área revegetada e verde o mais rápido possível, a fim de minimizar o impacto visual da degradação, protegê-la contra chuvas tropicais intensas e concentradas normalmente em determinada época do ano, bem como com o intuito de atender à legislação ambiental vigente, às pressões da sociedade $e$, eventualmente, às exigências de clientes 
internacionais, conforme GRIFFITH et al., (1996). Modelos de recuperação de solos degradados baseiam-se em tecnologias que, segundo DIAS et al. (1994), promovam não apenas a utilização de espécies de crescimento rápido, mas que sejam também capazes de melhorar o solo pelo aporte de matéria orgânica, melhoria esta que se faz tanto pela deposição de material vegetal como pela reciclagem de nutrientes.

SKERMAN (1977 apud LUCHESI, et al., 1992) afirma que a recuperação de solos pode ser buscada através de cobertura vegetal com espécies que tenham facilidade de estabelecimento, rápido desenvolvimento, agressividade suficiente para controlar invasoras, e que melhorem as condições físicas e a fertilidade do solo. No entanto, todas as características desejáveis para uma planta recuperadora geralmente não são encontradas em uma única espécie.

Diferentes enfoques vêm sendo considerados para o estabelecimento de modelos para a implantação de florestas mistas com espécies nativas, visando à recuperação de áreas degradadas (KAGEYAMA et al., 1992).

Segundo estes autores, a sucessão secundária é o mecanismo pelo qual as florestas tropicais se auto-regeneram através da cicatrização de locais perturbados (clareiras) ocasionados pela morte natural ou acidental de árvores. Estas clareiras são ocupadas por diferentes grupos ecológicos de espécies arbóreas, adaptadas para regenerarem-se em aberturas de tamanhos diferentes.

BUDOWSKI (1965, 1970 apud KAGEYAMA et al., 1992) identifica quatro grupos ecológicos de espécies arbóreas na regeneração de florestas: pioneiras, secundárias iniciais, secundárias tardias e, finalmente, as de clímax. KAGEYAMA et al. (1990, 1992 apud KAGEYAMA et al., 1992), trabalhando em recuperação de áreas nos entornos de reservatórios hidrelétricos, aplicaram esta classificação para plantios mistos aí introduzidos.

MUNSHOWER (1994) denomina este processo de sucessão natural e enfatiza que as pioneiras, também denominadas oportunistas, exibem elevada tolerância a extremos de temperatura, desequilíbrios químicos, deficiência em nutrientes e aridez; têm, ao mesmo tempo, elevada exigência quanto à luminosidade, raramente suportando ambientes sombreados. Uma vez estabelecidas, estabilizam o solo na área de distúrbio, reduzindo as 
temperaturas na superfície, aumentando o teor em matéria orgânica, reduzindo as perdas d'água por evaporação e contribuindo para um enriquecimento no conjunto de nutrientes do solo.

As características do solo, após o estabelecimento das oportunistas, acham-se modificadas o suficiente para permitirem o aparecimento de uma gama mais ampla de espécies vegetais que não tolerariam as condições extremas em termos de estrutura, nutrientes e umidade do local na condição anterior (MUNSHOWER, 1994).

Assim surgem as espécies secundárias, mais longevas que as pioneiras, que começam a imiscuir-se na comunidade de plantas, a acumular os nutrientes do solo e a penetrar suas raízes em espaços deixados pelas pioneiras mais velhas ou já mortas. As secundárias dão seqüência às modificações no ambiente iniciadas pelas pioneiras, de tal forma que estas últimas não mais conseguem reproduzir-se com sucesso no local. Em cada onda subseqüente na sucessão de espécies, cada grupo de plantas secundárias permanece mais tempo que a comunidade predecessora. Quando as mudanças no habitat não podem mais ser mensuradas num intervalo de tempo razoável, diz-se que a comunidade de plantas atingiu seu clímax ou seu ponto de máxima estabilidade (MUNSHOWER, 1994).

Avalia-se que centenas a milhares de anos são necessários para atingirse este estágio da sucessão em regiões áridas a semi-áridas, intervalo bem mais amplo que o requerido para a reabilitação natural em áreas mais favorecidas climaticamente (MUNSHOWER, 1994).

Obviamente, a lentidão dos processos naturais de recuperação numa área degradada não são aceitáveis pela sociedade, que deseja o retorno a algum tipo de ecossistema estável o mais rápido possível.

Assim, para MUNSHOWER (1994), a recuperação a ser promovida tem de condensar em poucos anos o trabalho que a natureza pode levar, nos seus processos de sucessão, alguns milhares.

Embora em recuperação de sítios degradados valha o ditado "cada caso é um caso", alguns enganos e atropelos são cometidos na urgência em estabelecer-se o tapete verde, segundo BARTH (1988 apud GRIFFITH et al., 1996) com a utilização de espécies introduzidas e agressivas, que podem 
prejudicar o estabelecimento dos grupos ecológicos subseqüentes, não sustentando os objetivos de longo prazo. Assim, em situações onde isso foi tentado, apareceram problemas tais como a necessidade de fertilizações freqüentes, a suscetibilidade dos monocultivos à destruição por pragas e pelo fogo, a erosão devido a falhas no tapete, o empobrecimento visual a médio prazo e a frustração dos administradores do empreendimento (GRIFFITH et al., 1996).

\subsection{O USO DE MATÉRIA ORGÂNICA EM REVEGETAÇÃO DE ÁREAS DEGRADADAS}

Como foi descrito, a revegetação constitui o etapa importante na recuperação das áreas de mineração cujos substratos são, segundo FRANCO et al. (1994), na maioria das vezes, ácidos e com baixa disponibilidade de nutrientes, especialmente o fósforo. Adicionalmente, todo o $\mathrm{N}$ e a maior parte do $\mathrm{P}$ e $\mathrm{S}$ disponíveis às plantas estão contidos na matéria orgânica do solo. Desta forma, a necessidade de reposição constante de matéria orgânica ao solo para o crescimento vegetal é função da reposição destes nutrientes.

MUNSHOWER (1994) afirma ser a matéria orgânica no solo freqüentemente definida como o seu teor em húmus, resíduo não identificável de plantas e animais, que se tornaram resistentes aos processos de decomposição. Entretanto, o termo é usado genericamente para designar o conteúdo de palha, esterco, raízes, fragmentos de madeira, mulches, entre outros, existentes no solo.

O termo "mulch" é muito comum na literatura americana sobre recuperação de solos. Agências ambientais reguladoras freqüentemente exigem a aplicação de matéria orgânica ou de mulches em áreas degradadas.

Segundo PLASS (1981), designam materiais orgânicos ou inorgânicos que, aplicados à superfície ou incorporados ao solo, têm a capacidade de proteger as sementes, reduzir a erosão e os extremos de temperatura a que o solo se sujeita, além de reduzir a evaporação, fatores importantes na disponibilidade de água ao crescimento da planta sob condições de aridez; podem também suprir uma quantidade limitada de nutrientes. MUNSHOWER 
(1994), em complementação, afirma terem a capacidade de aumentar a infiltração, reduzir a velocidade do vento na superfície do solo, protegê-lo do impacto das chuvas, agregar e reter pequenas partículas em seu local e prevenir encrostamentos. Quando incorporados, ao invés de aplicados a lanço, os mulches agem como corretivos orgânicos e seu impacto é mais pronunciado sobre a estrutura do solo, infiltração d'água, C.T.C., matéria orgânica total e ciclos dos nutrientes.

PLASS (1981) agrupa-os em dois tipos de resíduos:

- resíduos agrícolas, sendo os mais comuns a palha e o feno;

- resíduos de madeira, constituídos por cascas de árvores, serragens, resíduos de serrarias e resíduos do processamento de papel.

Para MUNSHOWER (1994), estercos, compostos e lodos de esgoto não constituem tecnicamente mulches, mas corretivos orgânicos.

Este autor alerta para o fato de os mulches provenientes de resíduos de madeira conterem pouco ou nenhum nitrogênio, além de elevarem a relação $\mathrm{C} / \mathrm{N}$; a fertilização nitrogenada é, pois, normalmente obrigatória quando de sua utilização. Assim, resíduos de madeira, suplementados com nitrogênio, são amplamente utilizados na reabilitação de minas abandonadas de bentonita nas Grandes Planícies no norte de Wyoming (EUA).

Quanto aos resíduos agrícolas, a palha provém principalmente de cereais como trigo e aveia; tal como os resíduos de madeira, contém também pouco ou nenhum $\mathrm{N}$, necessitando fertilização nitrogenada concomitante à sua utilização. Deve ser selecionada com algum cuidado para evitar-se a introdução de sementes daninhas ao sítio em recuperação. Quanto ao feno, é muito similar à palha, revelando desvantagens semelhantes, mas vantagens distintas. Por conter sementes de plantas nativas ao invés de grãos cereais, é benéfico ao desenvolvimento de uma maior diversidade na comunidade de plantas; normalmente contém pequena quantidade de $\mathrm{N}$ e, portanto, não requer, ou requer pouco, fertilização nitrogenada complementar, relativamente a outros mulches (MUNSHOWER, 1994).

Em âmbito nacional, os trabalhos técnicos na área de revegetação põem em destaque variados tipos de matéria orgânica, mas todos enfatizam claramente a sua utilidade. 
Desta forma, DIAS et al. (1994) afirmam que um dos fatores mais críticos da degradação é a remoção dos horizontes superficiais do solo, ricos em matéria orgânica, fundamentais à manutenção das condições físicas e químicas favoráveis e próprias à vida do solo.

ROLIM FILHO (1987 apud BONI et al., 1994) noticia o uso recente de efluentes de biodigestores - os biofertilizantes - além das tradicionais adubações verdes, na melhoria das propriedades do solo.

DIAS (1994) cita a utilização de dejetos animais no combate à erosão para evitar-se o desperdício de matéria orgânica no campo e/ou a contaminação de mananciais por eles.

SILVA et al. (1994) focalizam a utilização de composto de lixo e palhadas para a melhoria da fertilidade dos solos em áreas degradadas por minerações de areia no município de Jacareí (SP).

MOTTA NETO et al. (1994a), avaliando a recuperação das propriedades físicas de um solo degradado por mineração de xisto, utilizaram 3 consórcios de forrageiras com 3 tipos básicos de adubação, sendo um deles sem matéria orgânica (nos outros dois foram usados palhada e esterco bovino). Concluíram pela maior produção de matéria seca nos experimentos que levaram matéria orgânica. Em termos químicos, os mesmos autores, em outro trabalho (1994b) indicam também os experimentos com matéria orgânica como os mais promissores na recuperação do solo em questão, pelo aumento verificado na C.T.C. e nos teores de fósforo.

ALMEIDA et al. (1994), utilizando casca de pinus compostada conjunta à adubação verde em área de aterro de resíduos fabris sólidos, obtiveram estabelecimento da vegetação, aumento do número e freqüência de espécies animais, regularização da atividade biológica e da paisagem onde o diagnóstico original apontava para uma situação de deslizamentos, presença de voçorocas, concentração de resíduos, solo compactado, erosão laminar e em sulcos.

LEITE et al. (1994), em experimento visando a recuperação de área abandonada pela mineração de areia em Brasília - DF, utilizaram a descompactação do solo por gradagem conjunta à adubação orgânica com torta de mamona e "um tipo de turfa" (não especificada pelos autores). Apesar do aumento da capacidade de infiltração d'água no solo observou-se, num 
experimento testemunho sem adubação, que a descompactação isoladamente não foi suficiente para recolonizar a área, cujo índice de cobertura foi praticamente nulo. Já os experimentos com adição de matéria orgânica propiciaram uma maior disponibilidade de $\mathrm{P}, \mathrm{K}, \mathrm{Ca}$ e $\mathrm{Mg}$ no solo e o estabelecimento regenerativo de cerca de 70 espécies de plantas.

WISNIEWSKI et al. (1997), em experimento com lodo de esgoto na recuperação de áreas degradadas por mineração de calcário, concluem que, incorporado nos $10 \mathrm{~cm}$ superficiais do solo, o lodo promoveu ligeiro aumento dos teores de P, Mg, C.T.C., micronutrientes e teores foliares de Mg; entretanto, conferiu $\mathrm{Cr}$ ao terreno, a níveis próximos aos valores críticos.

Segundo o mesmo autor, o tratamento com lodo de esgoto, pela natureza do material, pode resultar em aumento de metais pesados na cadeia alimentar, seja pelo consumo direto de vegetais, seja indiretamente, através de produtos derivados de animais; esta absorção dependerá da concentração dos metais pesados no lodo, do genótipo da planta e do período de interação entre os metais do lodo e o solo.

Outro inconveniente reside no teor elevado de umidade, o que prejudica sua manipulação e limita sua aplicação a pequenas distâncias de transporte.

Do exposto, tendo em vista que terrenos remanescentes da atividade extrativa mineral e seus entornos já não mais possuem a fertilidade necessária para dar suporte a novas culturas, depreende-se a necessidade de lançar mão não apenas de técnicas de plantio e manejo, mas também de produtos para respostas satisfatórias aos esforços em recuperação ambiental.

Justifica-se, pois, a validade da presente proposta de estudos, ao caracterizar a turfa como uma fonte riquíssima de matéria orgânica naturalmente humificada, amplamente disponível em várias regiões do país, como coadjuvante diferenciado na recuperação ambiental de solos degradados. 


\section{MATERIAIS E MÉTODOS}

Conforme salientado anteriormente, a presente proposta enfatiza o estudo e interpretação de alterações nas propriedades físico-hídricas e químicas em um solo, após a adição de turfa em quantidades variáveis.

O solo é proveniente de uma área submetida à extração de areia para construção civil, atualmente em fase de recuperação ambiental, localizada no bairro Meia Lua, município de Jacareí - SP; a turfa é proveniente da turfeira SJ-II, município de São José dos Campos - SP (IPT, 1978).

O estudo pretendido impõe a caracterização prévia dos materiais utilizados, o que é abordado a seguir.

\subsection{SOLO}

O solo existente no módulo em recuperação foi trazido das proximidades da área, sendo, portanto, um solo alóctone. Nesta região, tem sido este o procedimento padrão na reconstituição topográfica e florística de áreas em processo de recuperação ambiental, uma vez que o solo original raramente é estocado ou preservado quando do decapeamento da jazida.

Tendo em vista a similaridade dos ambientes de sedimentação e a proximidade da área de empréstimo à área em recuperação, pode-se assumir, com segurança, uma semelhança entre o solo autóctone e o alóctone.

Em sua área de origem, o solo apresenta horizonte $A$ pouco espesso e ligeiramente arenoso, horizonte $B$ bastante argiloso e de coloração acinzentado-clara. Segundo o mapa pedológico do Estado de São Paulo, escala 1:500.000 (OLIVEIRA et al., 1999), os solos presentes nesta região estão englobados na categoria dos "gleissolos melânicos", variedade "hidromórficos cinzentos". Constituem extensa unidade no vale do Rio Paraíba do Sul, coincidentes com sua várzea e com as de seus principais afluentes, mapeável desde o norte de Jacareí até o município de Cruzeiro, e com largura que pode atingir até $8 \mathrm{Km}$; sofre interrupções em sua faixa de ocorrência na 
altura dos municípios de São José dos Campos, Caçapava e Guaratinguetá, pela interposição de "línguas" da unidade "latossolos vermelho-amarelos".

Segundo OLIVEIRA (1999), os gleissolos apresentam sérias limitações impostas pela presença do lençol freático a pouca profundidade, além de aeração inadequada, fato que inibe o crescimento das raízes; o ambiente redutor facilita a formação de compostos bivalentes de $\mathrm{Fe}$ e $\mathrm{Mn}$, sempre fitotóxicos. Os gleissolos, segundo o autor, são distróficos em sua maioria e bastante ácidos, o que requer manejo específico, com aplicação de corretivos e fertilizantes para produtividade satisfatória.

A área em recuperação pode ser vista nas fotos 1 e 2 , a seguir.

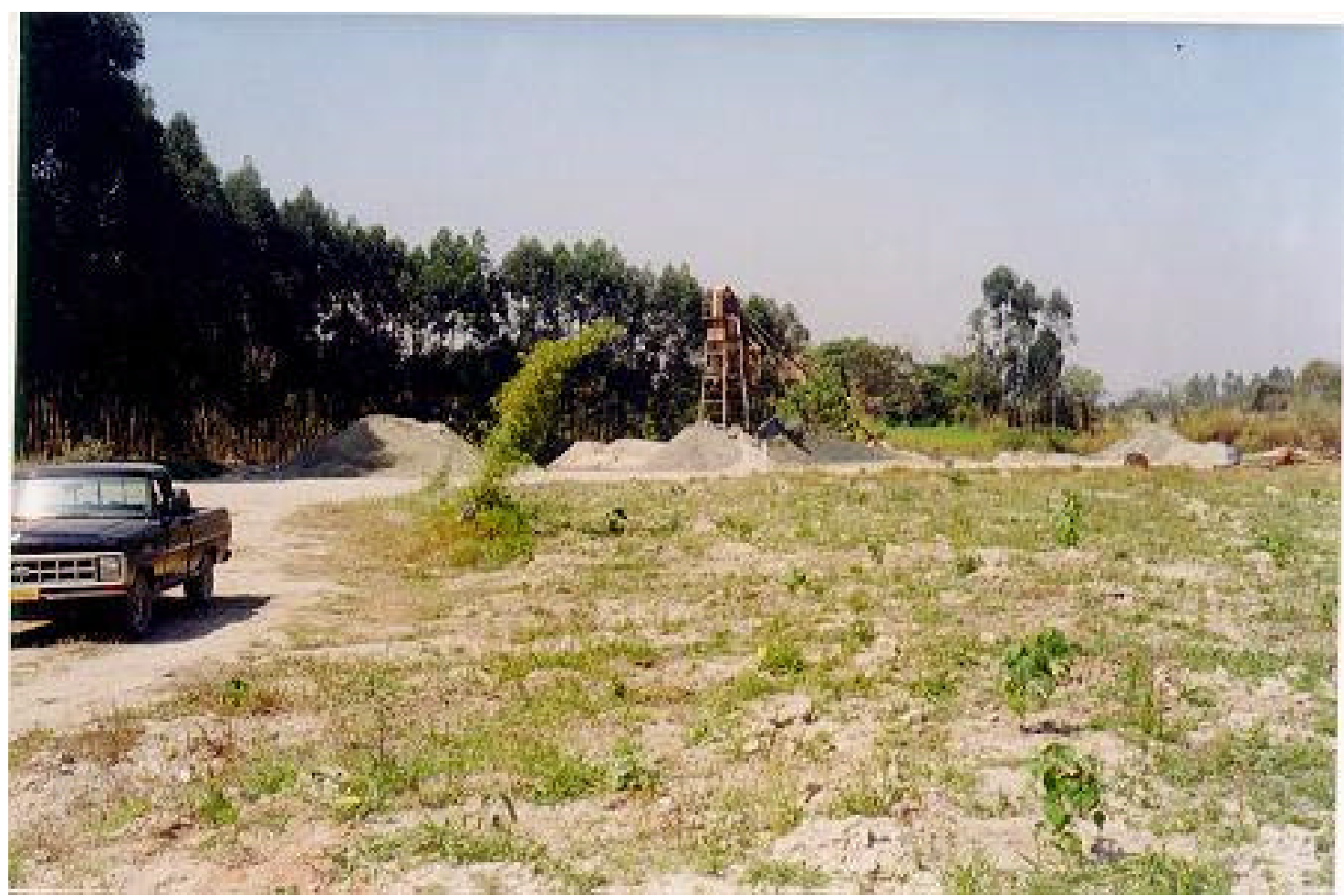

Foto 1 - área em recuperação ambiental, podendo-se notar mudas de pioneiras recémtransplantadas

Coletaram-se cerca de $40 \mathrm{Kg}$ de solo em área de aproximadamente tha às margens do Rio Paraíba do Sul, em pontos espaçados entre si de cerca de $20 \mathrm{~m}$ segundo uma malha regular, à profundidade média de amostragem de $20 \mathrm{~cm}$. 
Em laboratório este material foi peneirado para eliminação da fração maior que $2 \mathrm{~mm}$ (inerte e normalmente constitutiva do horizonte $\mathrm{C}$ ), sucessivamente homogeneizado em pilhas alongadas e reduzido por quarteamento para fornecer alíquotas, representativas da amostra total, aos diversos ensaios.

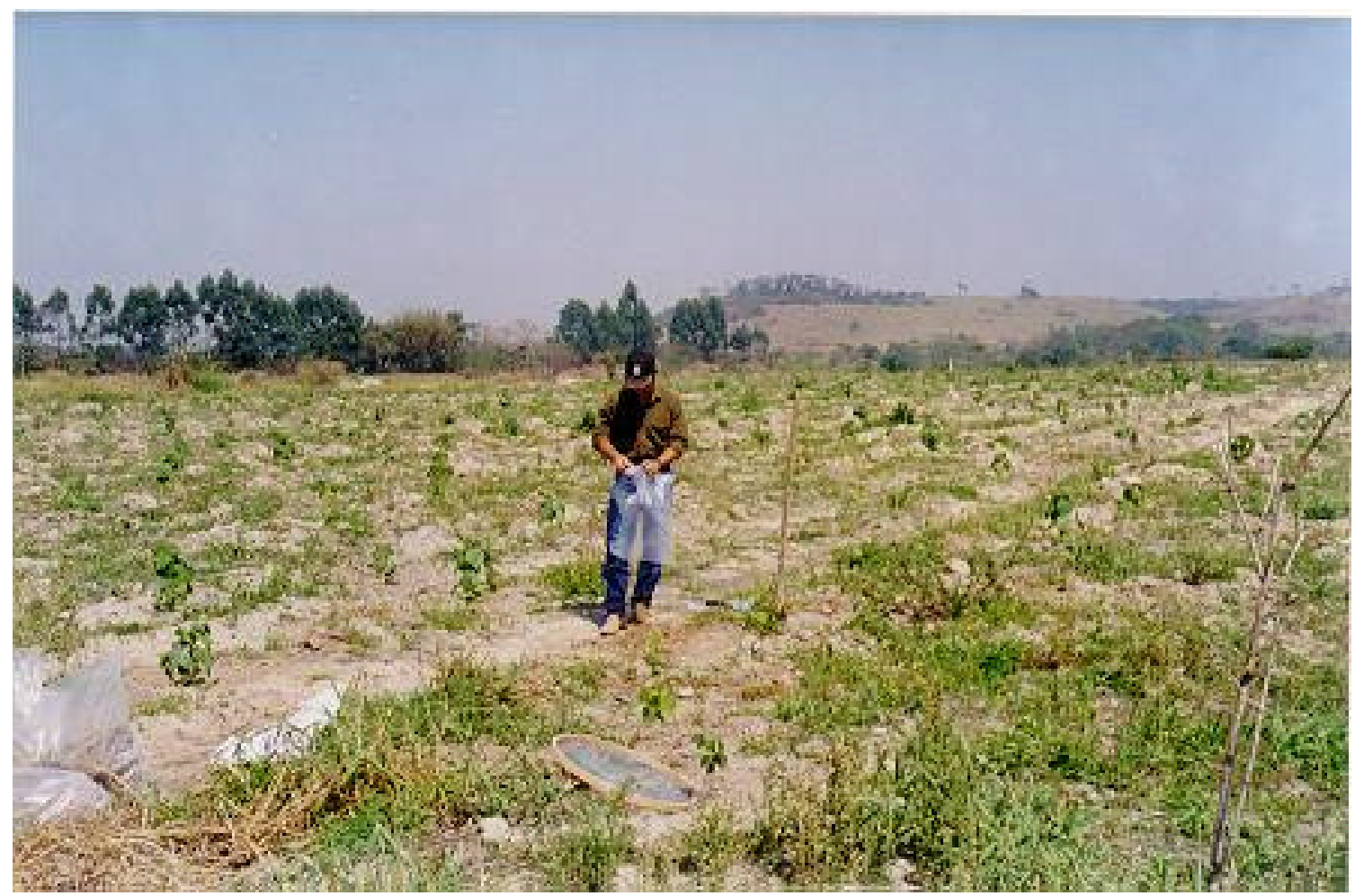

Foto 2 - mesmo local da foto anterior, onde foram coletadas as amostras de solo

O material foi caracterizado através de análise mineralógica por Difração de Raios- $\mathrm{X}$, análise química por Fluorescência de Raios- $\mathrm{X}, \mathrm{pH}$, determinação dos teores em umidade, matéria orgânica, Capacidade de Troca de Cátions (CTC), densidade das partículas (ou densidade real), densidade aparente, distribuição granulométrica e alguns parâmetros indicativos de sua fertilidade $[\mathrm{V}(\%)$ e $\mathrm{m}(\%)]$, através dos procedimentos a seguir descritos. 


\subsubsection{Umidade}

Umidade, ou umidade base seca $\left(\mathrm{H}_{\mathrm{s}}\right)$, é o teor de água no solo relativo à sua massa seca, ou seja, expressa em \% a quantidade d'água adicionada ou incorporada a uma amostra, sendo definida por:

$$
\mathrm{H}_{\mathrm{s}}(\%)=\frac{\mathrm{m}_{\mathrm{u}}-\mathrm{m}_{\mathrm{s}}}{\mathrm{m}_{\mathrm{s}}} \times 100
$$

onde: $\mathrm{m}_{\mathrm{u}}=$ massa da amostra úmida

$m_{\mathrm{s}}=$ massa da amostra seca em estufa a $105^{\circ} \mathrm{C}$, até peso constante.

Sob esta conceituação, é bastante utilizada na indústria de tratamento de minérios.

Pode também ser definida em base úmida $\left(\mathrm{H}_{\mathrm{u}}\right)$, ou seja, expressando a quantidade de água existente numa amostra relativamente à sua massa total:

$$
H_{u}(\%)=\frac{m_{u}-m_{s}}{m_{u}} \times 100
$$

Sob esta conceituação, é mais utilizada para análises laboratoriais, quando se deseja equalizar misturas de materiais (como no caso da presente pesquisa) e em cálculos envolvendo definição de reservas geológicas.

\subsubsection{Análise mineralógica por difração de raios-X}

Segundo FRONZAGLIA (1999), a técnica de difração de raios-X (DRX) consiste na incidência dos raios-X em uma amostra e na detecção dos fótons difratados (feixe difratado). Em átomos arranjados periodicamente no espaço o fenômeno da difração ocorre nas direções de espalhamento que satisfazem a Lei de Bragg, expressa por:

$n \lambda=2 d \operatorname{sen} \theta$ 
onde: $\lambda=$ comprimento de onda do feixe incidente;

$\mathrm{n}=$ ordem de difração;

$\theta$ = ângulo de incidência (ou ângulo de Bragg); e

d = distância entre os planos de átomos, característica para cada composto cristalino e que vai permitir sua identificação (distância interplanar).

O feixe difratado é expresso através de picos que se destacam do background (ou linha de base), registrados num difratograma de intensidade versus ângulo $2 \theta$.

Ainda segundo a mesma autora, os picos observados no difratograma representam as intensidades obtidas em ângulos $2 \theta$ nos quais o feixe incidente é difratado por um determinado conjunto de planos de mesma distância interplanar.

A identificação das espécies mineralógicas no difratograma foi feita por comparação com padrões difratométricos de minerais do banco de dados do software IDENTIFY (Philips).

Os padrões foram escolhidos em função da expectativa de ocorrência de determinada assembléia mineralógica na amostra de solo em estudo, tendo em vista a associação feita às rochas que compõem o arcabouço geológico regional. O programa realiza a comparação das posições angulares e intensidades de picos característicos de cada mineral selecionado, individualmente, com aquelas obtidas no difratograma; a presença do mineral correspondente é diagnosticada em caso de coincidência do padrão em análise com o difratograma.

A moagem da amostra foi realizada em moinho laboratorial planetário, de bolas de ágata, por 20 minutos, previamente à prensagem manual da pastilha.

O instrumento utilizado foi um difratômetro marca Philips modelo MPD 1880-PW1710, que operou com emissão de feixe de radiação $X$ de CuK $\alpha$ a $40 \mathrm{kV}, 40 \mathrm{~mA}$, varrendo a faixa angular de 2,5 a $80^{\circ}$, com passo de $0,02^{\circ} \mathrm{e}$ tempo de coleta por passo de 1s. 


\subsubsection{Determinação do tamanho de partículas}

O tamanho dos grãos constitui uma das propriedades físicas fundamentais dos solos. A análise que permite conhecer sua expressão quantitativa é dita análise granulométrica, e várias são as técnicas disponíveis para a sua realização.

Estas análises permitem caracterizar, classificar e correlacionar os tipos de solo, eventualmente permitindo prever certos comportamentos frente a problemas agronômicos, geotécnicos, etc.

O método aqui utilizado emprega técnicas de análise de imagem por varredura de campo.

É um método óptico para determinação da distribuição de tamanho de partículas utilizando espalhamento laser de baixo ângulo, em que o espalhamento da luz é relacionado à distribuição do tamanho de partículas (FRONZAGLIA, 1999).

O feixe é controlado por lentes de modo a atingir a amostra, em meio aquoso, de formas variáveis. As partículas são mantidas em suspensão por um fluxo constante induzido por um agitador e bomba, de maneira a não propiciar exposições, em maior número, de faces mais "privilegiadas" das partículas; utilizou-se ultra-som como auxílio à dispersão das partículas.

A interação feixe de laser/amostra gera uma difração do feixe que é focalizado, por um conjunto de lentes, no centro de um detetor de silício fotossensível ligado a um sistema computadorizado. No detetor é realizada uma contagem estatística de modo que uma mesma partícula poderá ser "contada", sob diferentes ângulos de projeção, cerca de 4000 a 5000 vezes.

Tendo em vista possíveis interferências da matéria orgânica do solo, principalmente na forma de raízes, a amostra foi previamente submetida à calcinação controlada em mufla laboratorial - elevação da temperatura à patamares múltiplos de $100^{\circ} \mathrm{C}$, com residência de 1 hora em cada patamar até atingir $550^{\circ} \mathrm{C}$ quando, então, foi deixada por 18 horas nesta temperatura antes de se desligar a mufla.

Foram realizadas 10 varreduras na amostra para minimizar flutuações estatísticas, sendo considerado como resultado final a média destas. 
O equipamento utilizado é da marca MALVERN, modelo Master Sizer, que permite cobrir faixas de tamanho de partículas de 0,05 a 3500 $\mu \mathrm{m}$.

As medidas são expressas através da distribuição do tamanho de partículas em volume; os diâmetros estatísticos utilizados, $d_{90}, d_{50}$ e $d_{10}$ representam o tamanho abaixo do qual se encontram, respectivamente, $90 \%$, $50 \%$ e $10 \%$ da distribuição acumulada no passante.

O software fornece, adicionalmente, os seguintes parâmetros estatísticos:

- $\mathrm{D}[4,3]$, que representa a média da distribuição do tamanho de partículas medida pelo volume (em $\mu \mathrm{m})$;

- $\quad \mathrm{D}[3,2]$, que representa a média da distribuição do tamanho de partículas medida por área $(\mathrm{em} \mu \mathrm{m})$.

\subsubsection{Análise química por fluorescência de raios-X}

A técnica consiste na excitação dos elementos químicos de uma amostra pela incidência de um feixe de raios-X produzido por um tubo. A interação do feixe com a amostra pode ocasionar a absorção dos fótons do feixe provocando o deslocamento de um elétron da camada K. O posterior preenchimento desta vacância por outro elétron, proveniente de camadas eletrônicas mais externas (L, M ou N) gera, segundo RATTI (1994), uma radiação secundária dita fluorescente, característica do átomo que a emitiu.

No equipamento de raios- $X$, a radiação fluorescente é colimada, difratada por cristais segundo a referida Lei de Bragg ( $n \lambda=2 d \operatorname{sen} \theta$ ) e captada por detectores que a convertem em pulsos elétricos. Estes pulsos são amplificados e acionam circuitos de contagem (cintilador, Geiger ou contador proporcional). O equipamento fornece, então, contagens, proporcionais ao tempo de leitura e à concentração do elemento emissor na amostra; a comparação com amostras de teor conhecido (naturais ou misturas de óxidos) fornece a dosagem do elemento pesquisado (RATTI, 1994).

Ainda segundo RATTI (inf. oral), trata-se de técnica rápida (análise realizada em poucos minutos), não destrutiva (podendo-se reaproveitar a amostra) cobrindo praticamente todos os elementos da Tabela Periódica, à 
exceção de gases nobres (menos Ar). Permite a análise de sólidos, líquidos e gases.

A amostra foi moída em moinho de anéis e prensada em prensa automática marca HERZOG na forma de pastilha, previamente à realização da análise, dita semi-quantitativa.

A análise é assim qualificada por adotar como procedimento básico a varredura de todos os elementos possíveis de se encontrar na amostra.

\subsubsection{Determinação do pH}

As determinações de $\mathrm{pH}$ foram feitas pelo método potenciométrico $(\mathrm{pH}$ em água, $\mathrm{KCl} 1 \mathrm{~N}$ e $\mathrm{CaCl}_{2}$ 0,01M), conforme metodologia descrita em BRASIL (1997).

Por este método, num béquer de $100 \mathrm{ml}$, adiciona-se $25 \mathrm{ml}$ de líquido (água destilada e deionizada, $\mathrm{KCl} 1 \mathrm{~N}$ ou $\mathrm{CaCl}_{2} 0,01 \mathrm{M}$ ) a $10 \mathrm{~g}$ de amostra. Agitase a solução com bastão de vidro deixando-a repousar por tempo não inferior a 1h. Agita-se novamente a amostra com o bastão de vidro, mergulham-se os eletrodos do potenciômetro na suspensão homogeneizada e procede-se à leitura do pH. O potenciômetro deve estar aferido com soluções tampão pH 4,0 e pH 7,0 e ser ligado ao menos 30 minutos antes da utilização.

\subsubsection{Determinação da Capacidade de Troca de Cátions, V(\%) e m(\%)}

A Capacidade de Troca de Cátions (CTC) é uma propriedade peculiar a certos minerais constituintes do solo, principalmente os da fração argilosa, de trocar cátions fixados na superfície ou dentro dos canais do retículo cristalino, em solução aquosa. Normalmente, é função de desbalanceamentos eletrônicos existentes nos reticulados cristalinos desses argilominerais, ligações quebradas nas arestas das partículas (e, conseqüentemente, da área específica) e de colóides orgânicos associados às partículas. Segundo BRASIL (1997), é definida para o solo como sendo a soma total dos cátions que podem ser 
retidos na superfície coloidal prontamente disponível à assimilação pelas plantas.

Analiticamente, estes cátions são removidos por soluções salinas de amônio, cálcio, bário e soluções ácidas diluídas para, posteriormente, serem quantificados por métodos volumétricos, de emissão ou absorção atômica, conforme descrito em BRASIL (1997).

A CTC é numericamente expressa por:

$\mathbf{T}=\mathbf{S}+\left[\mathbf{H}^{+}+\mathbf{A l}^{3+}\right] \quad$ onde: $\mathrm{T}=$ valor da CTC (em $\mathrm{cmol}_{\mathrm{C}} / \mathrm{kg}^{1}$ de solo);

$$
\begin{aligned}
& \mathrm{S}=\left[\mathrm{Ca}^{++}+\mathrm{Mg}^{++}+\mathrm{Na}^{+}+\mathrm{K}^{+}\right]=\text {soma dos } \\
& \text { cátions trocáveis ou soma de bases; e } \\
& {\left[\mathrm{H}^{+}+\mathrm{Al}^{3+}\right]=\text { acidez trocável }}
\end{aligned}
$$

Há, para o solo, alguns parâmetros complementares indicadores de sua fertilidade e derivados destas determinações.

Desta forma, o valor $\mathrm{V}(\%)$ corresponde ao percentual de saturação de bases, expresso por:

$\mathrm{V}=\frac{\mathrm{S}}{\mathrm{T}} \times 100$

Este parâmetro refere-se à proporção de cátions básicos trocáveis em relação à Capacidade de Troca determinada a pH 7. Alta saturação específica, distinção de solos com saturação por bases igual ou superior a 50\%, caracteriza solos eutróficos, ao passo que baixa saturação específica distingue solos com saturação por bases inferior a 50\%, caracterizando os solos distróficos.

O valor $\mathrm{m}(\%)$ é definido como o percentual de saturação com alumínio trocável, elemento fitotóxico quando em altas concentrações, sendo utilizado para classificar solos quanto ao caráter álico ( $m>50 \%)$; é expresso por:

\footnotetext{
${ }^{1} \mathrm{Cmol}_{\mathrm{c}} / \mathrm{kg}$ = centimol de cátions por quilograma de solo seco (equivalente a $\mathrm{mEq} / 100 \mathrm{~g}$, em desuso)
} 


$\mathrm{m}=\frac{\mathrm{Al}^{3+}}{\mathrm{S}+\mathrm{Al}^{3+}} \times 100$

\subsubsection{Determinação da densidade real das partículas}

É expressa como sendo a razão entre a massa e o volume exclusivamente das partículas sólidas do solo. Foi determinada por picnometria, conforme procedimento descrito por BLAKE \& HARTGE (1987) para a fração $<2 \mathrm{~mm}$.

Tal método consiste nas determinações quantitativas de massa e do volume dos sólidos do solo. A massa é obtida por pesagem após secagem a 105ํㄷ; o volume é calculado a partir da massa e densidade do líquido deslocado pela amostra no picnômetro.

A densidade das partículas $\rho_{p}$ é expressa por:

$$
\rho_{p}=\frac{\rho_{w}\left(W_{s}-W_{a}\right)}{\left(W_{s}-W_{a}\right)-\left(W_{s w}-W_{w}\right)}
$$

onde:

$\rho_{\mathrm{w}}=$ densidade da água à temperatura observada no ensaio;

$\mathrm{W}_{\mathrm{s}}=$ peso do picnômetro + amostra

$\mathrm{W}_{\mathrm{a}}=$ peso do picnômetro vazio

$\mathrm{W}_{\mathrm{sw}}=$ peso do picnômetro + amostra + líquido

$\mathrm{W}_{\mathrm{w}}=$ peso do picnômetro + líquido

\subsection{A TURFA}

A turfa é proveniente da porção superficial do depósito SJ-II, constituindo material representativo dos litotipos fibrosos nele presentes e atualmente em comercialização pela empresa que detém os direitos minerários. A foto 3 ilustra um dos campos de extração da jazida - unidades de 1 ha (20 x 500 metros) separadas entre si por valetas de $1 \mathrm{~m}$ de profundidade para rebaixamento do 
lençol freático -, e a foto 4 , a extração do minério, de onde foram obtidas as amostras para o presente estudo.

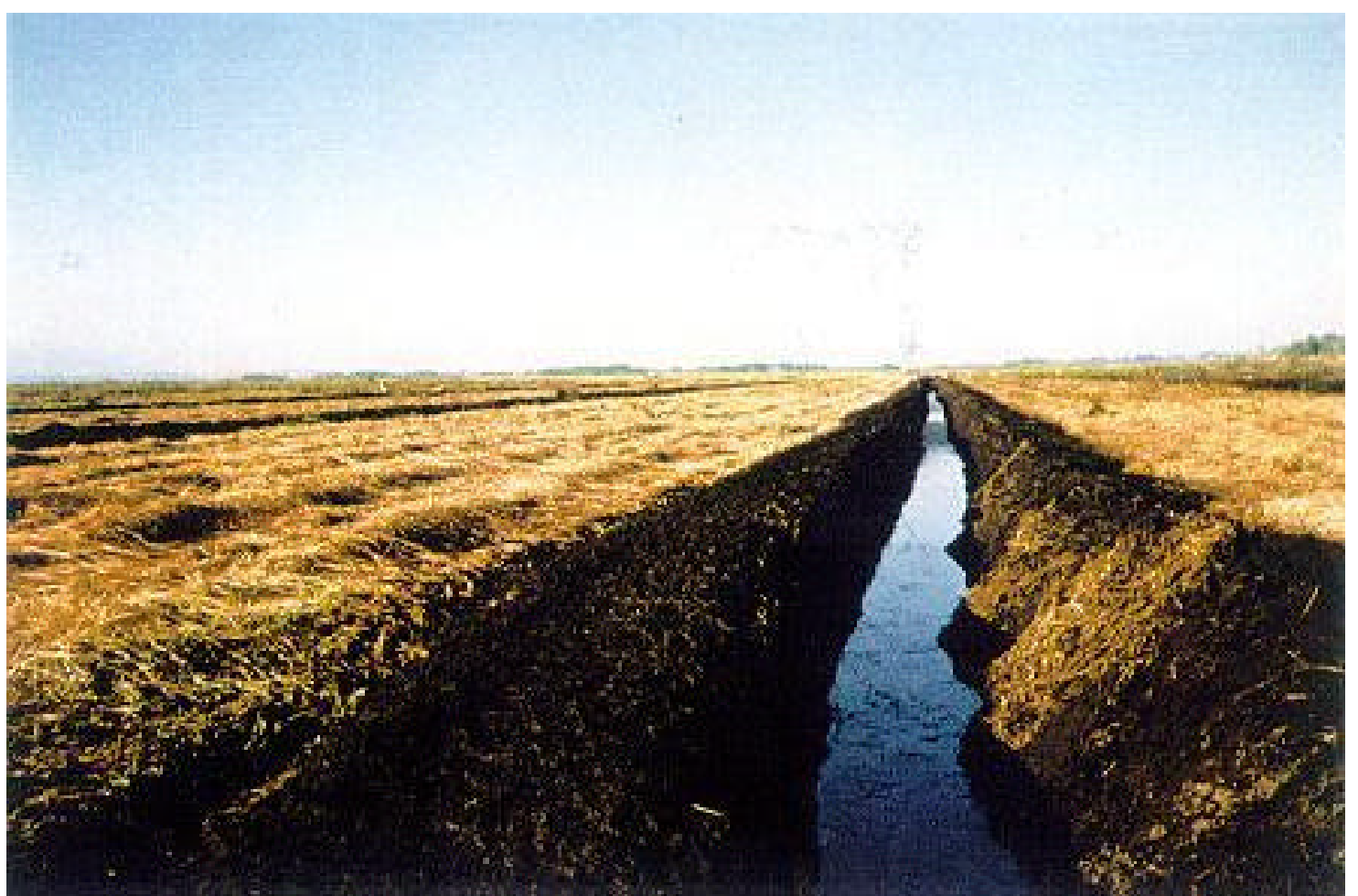

Foto 3 - campo de extração de turfa

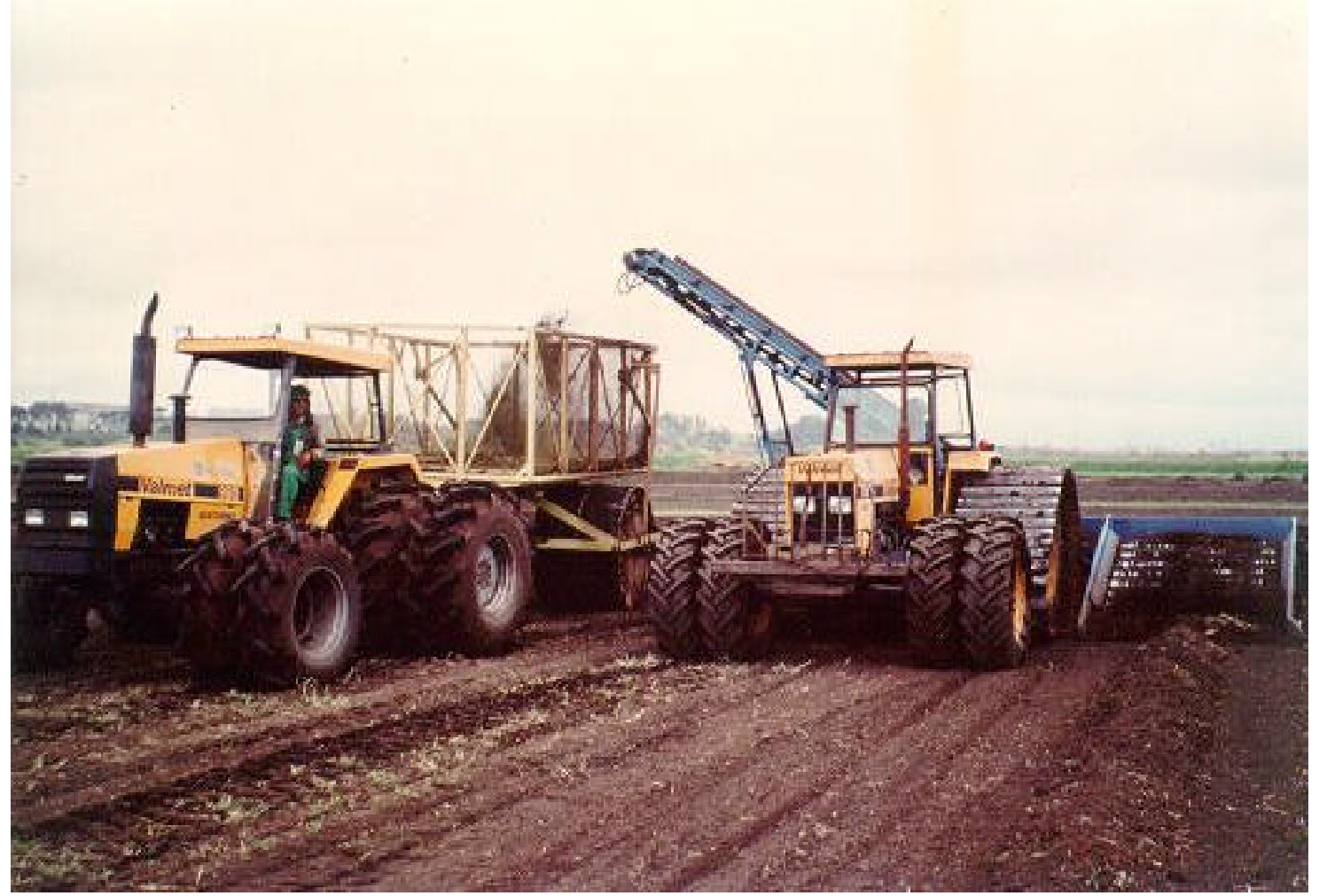

Foto 4 - operação de extração comercial do minério 
Foram caracterizados os parâmetros mais importantes tendo em vista a utilização pretendida: grau de decomposição (von Post), pH, teor em matéria orgânica e quimismo dos principais elementos constituintes (carbono total, carbono orgânico, N, P, K, Ca, Mg e S), segundo metodologia adotada pelo Laboratório de Solos da Escola Superior de Agricultura Luiz de Queiroz (ESALQ).

De modo análogo ao procedimento adotado para as amostras de solo e visando à sua conformação aos ensaios previstos, a turfa foi também peneirada para eliminação de raízes, galhos e material lenhoso menos decomposto, com tamanho superior a $2 \mathrm{~mm}$, homogeneizada em pilhas alongadas (foto 5 ) e reduzida por quarteamento.

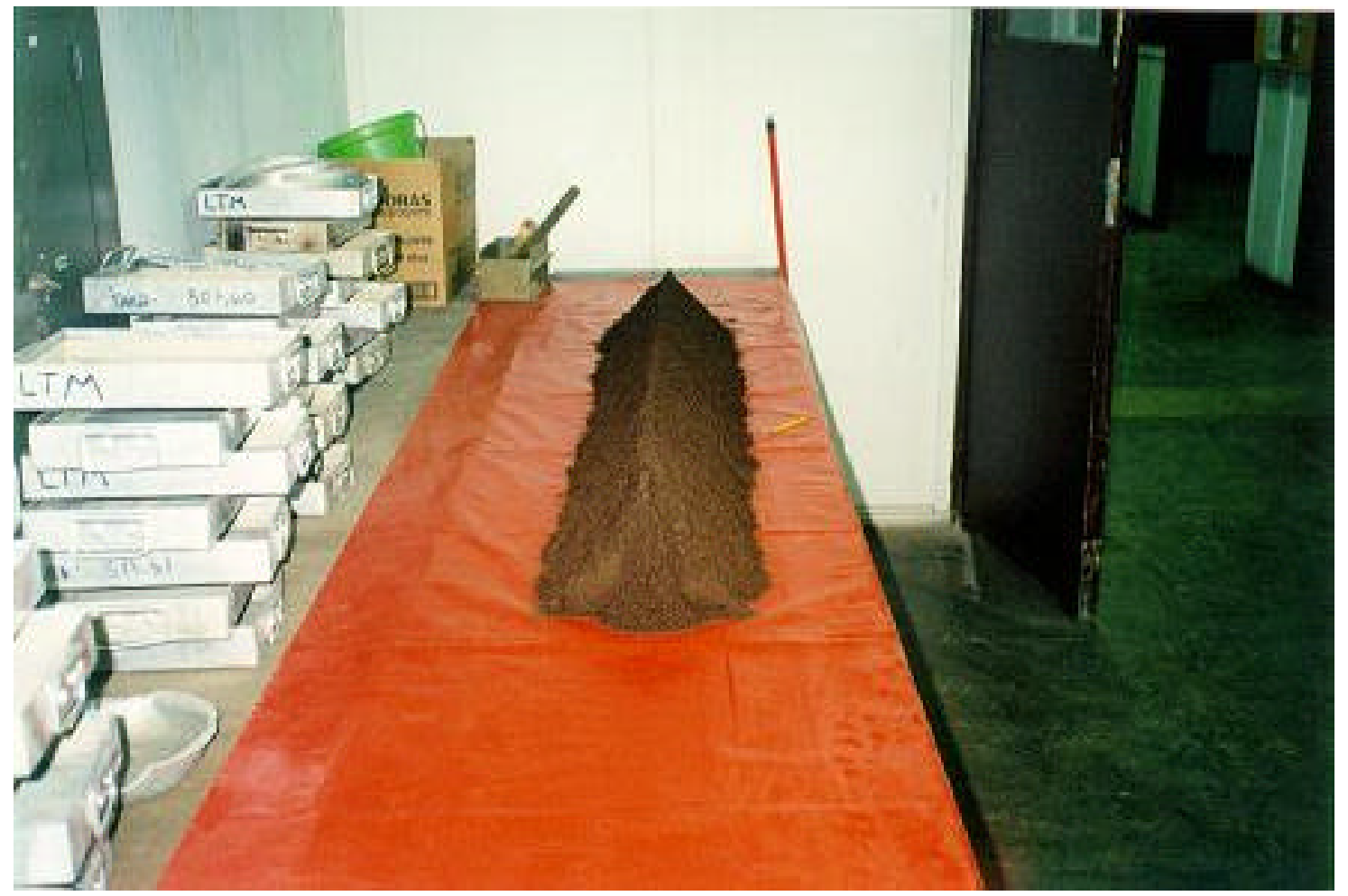

Foto 5 - homogeneização da turfa em pilhas alongadas 


\subsection{A ADIÇÃO DE TURFA AO SOLO}

O estudo constituiu um comparativo entre resultados de ensaios efetuados em amostras do solo, homogeneizadas em laboratório na condição de testemunho ("branco"), de um lado, e com adição de turfa em diferentes proporções, de outro.

As adições de turfa foram feitas em 4 condições em peso (2-4-6-8\%) visando aferir se alguma delas poderia adequar-se mais satisfatoriamente à melhoria das condições gerais do solo em questão. Para que houvesse uniformidade nestas avaliações, as misturas foram preparadas tomando-se por base a massa seca destes materiais (foto 6).

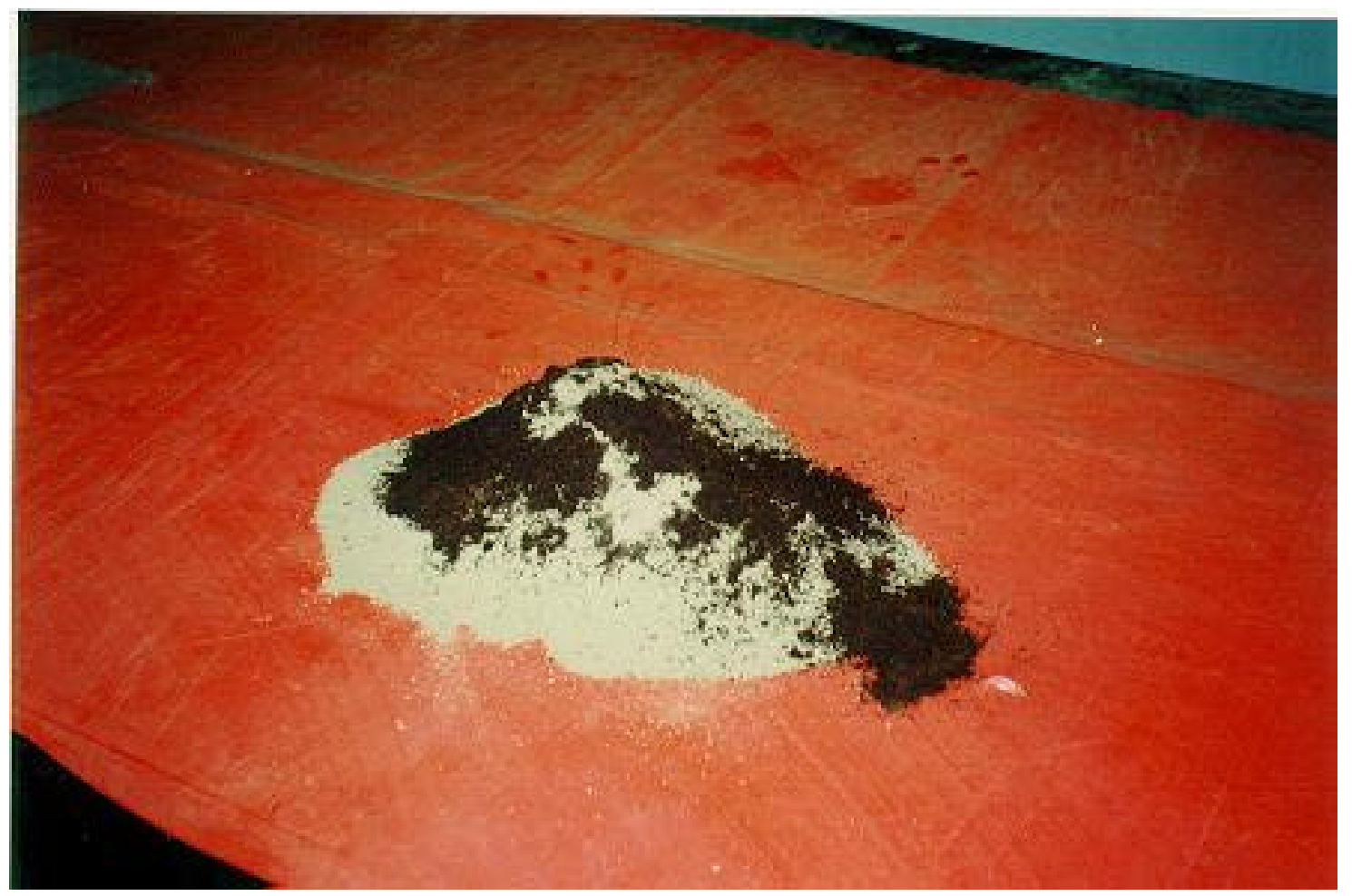

Foto 6 - adição de turfa ao solo

A avaliação da eficácia da utilização da turfa deu-se através da mensuração dos parâmetros físicos e químicos mais influentes na produtividade dos solos: densidade aparente, porosidade (macro, meso e micro porosidade), condutividade hidráulica, poder tampão e C.T.C. 
As misturas foram também homogeneizados em pilhas alongadas e reduzidas por quarteamento para fornecerem as alíquotas aos diversos ensaios.

\subsection{CONFORMAÇÃO DAS AMOSTRAS AOS ENSAIOS FísICOS}

Para os ensaios físicos houve necessidade de submeter-se as amostras a um procedimento padrão de compactação para conformação aos equipamentos utilizados.

Ressalte-se que, nestas condições, os resultados analíticos obtidos devem ser entendidos à luz da manipulação efetuada com as amostras (exclusão da fração > 2mm, incorporação de turfa, homogeneização e compactação), podendo diferir substancialmente daqueles que seriam obtidos caso os ensaios fossem realizados em amostras indeformadas, ou seja, coletadas numa situação pós-recuperação da área e com vegetação já implantada, através de amostradores especiais à coleta de amostras para ensaios físico-hídricos (modelo UHLAND); este fato não invalida, entretanto, os procedimentos aqui adotados tendo em vista o caráter eminentemente comparativo do presente estudo.

Não se considerou, assim, qualquer mensuração envolvendo testes de crescimento de mudas, em campo ou em casa de vegetação; o fato de o estudo limitar-se exclusivamente às condições laboratoriais - envolvendo intenso manuseio das amostras - justifica-se por refletir a situação real no tratamento de solos degradados, onde se pretenda restaurar a cobertura vegetal, uma vez que em jazidas já esgotadas pela atividade extrativa os procedimentos de recuperação ambiental envolvem regularização topográfica e descompactação do solo para a calagem e adubação prévios à etapa de semeadura ou transplante de mudas.

A compactação promovida é baseada no método da "massa específica aparente compactada", que tem como norma de referência a BS-1460 (BRITISH STANDARDS INSTITUTION, 1967). 
Neste procedimento, o volume da amostra é medido após sua compactação em uma proveta colocada em uma "caixa de compactação", que consiste num dispositivo de madeira construído para adaptar a proveta, bipartido verticalmente, com as folhas articuladas por dobradiças, dotado de uma trave horizontal a uma altura de $7 \mathrm{~cm}$ (figura 5). Uma vez encaixada no dispositivo, a proveta é erguida manualmente pela extremidade superior até que o ressalto da base, protegido por um anel de borracha, toque na trave; soltando-se a proveta, promove-se a compactação da amostra. Este movimento é repetido, de acordo com a norma, 50 vezes antes de se registrar o volume compactado.

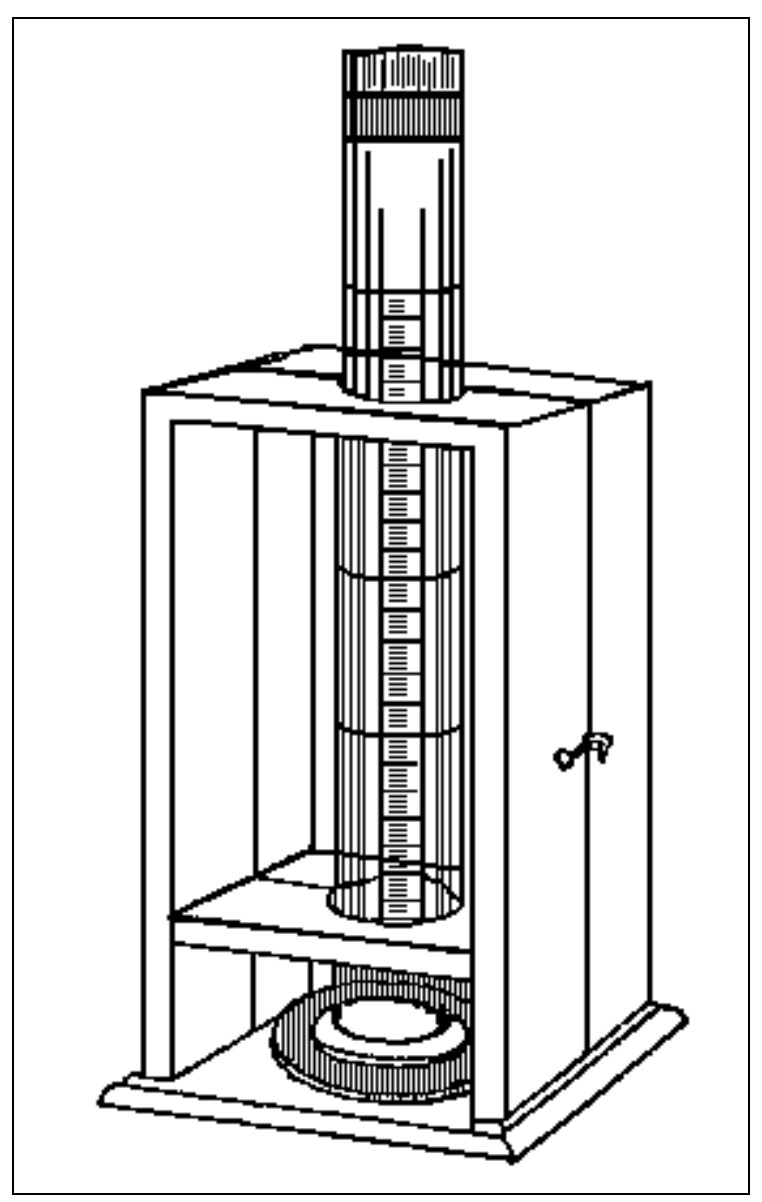

Fig. 5 - dispositivo de compactação (mod. de BSI, 1967)

Para o presente caso, a submissão de todas as amostras a um procedimento padrão de compactação é a garantia de que os resultados analíticos obtidos para cada uma individualmente sejam comparáveis entre si. 
Ademais, como será visto, este procedimento será imprescindível aos ensaios para determinação da porosidade e condutividade hidráulica, tendo em vista os equipamentos laboratoriais e métodos utilizados.

A compactação das amostras foi realizada num conjunto formado por uma pequena peça cilíndrica de alumínio tendo disposto sobre si um cilindro maior ("cabeça" do conjunto), utilizado como volume extra para armazenar a amostra e contribuir à compactação; este aparato é tampado nas extremidades e travado por uma estrutura de 3 fusos com a extremidade inferior dotada de tampa circular de aço inox de diâmetro igual ao dos cilindros (foto 7).

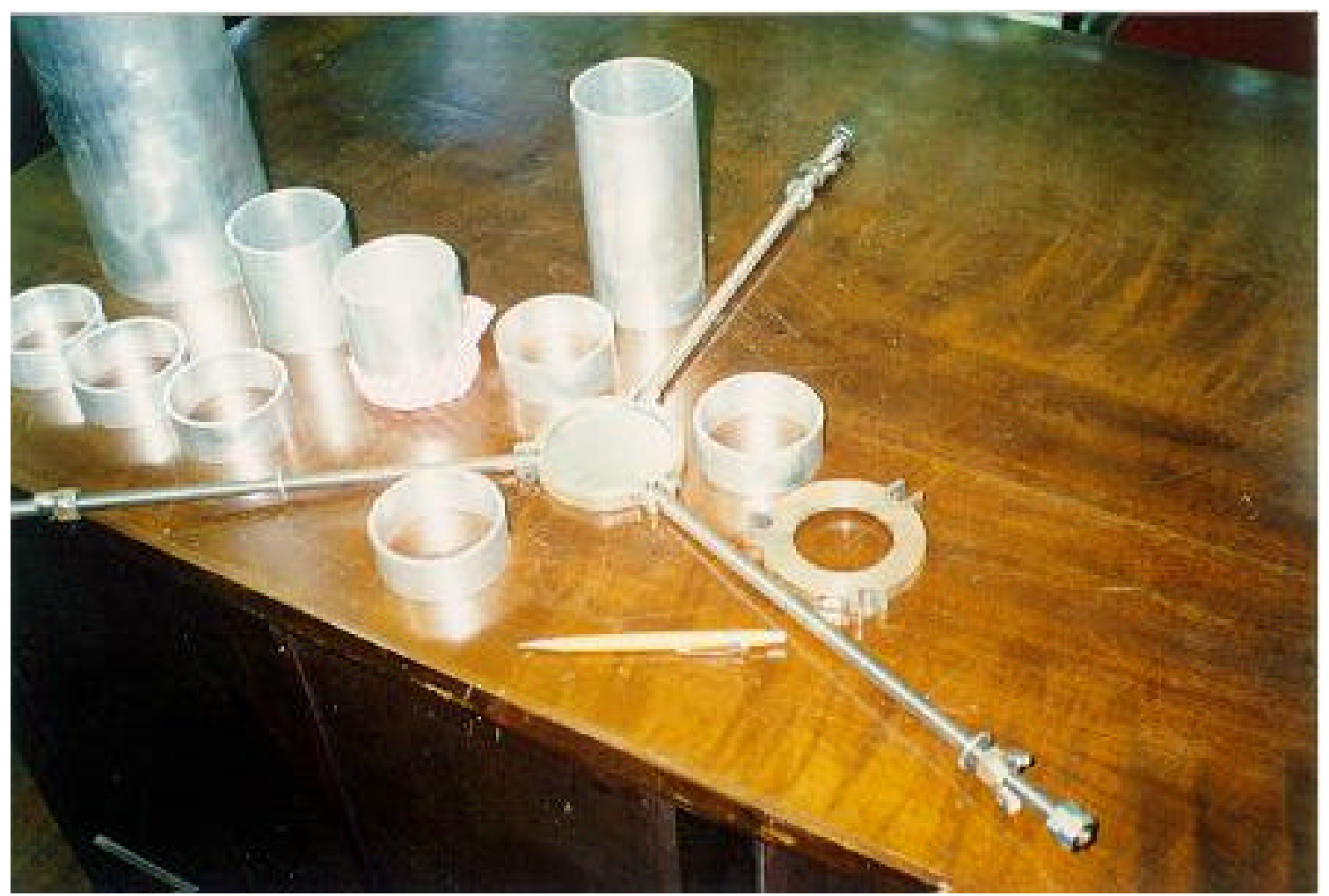

Foto 7 - conjunto utilizado na compactação das amostras

Utilizaram-se 2 tipos diferentes de cilindros, conforme o ensaio a que se destinava a amostra; o de altura menor é aqui informalmente denominado "anel”. São peças de alumínio de 69,8mm (23/4") de diâmetro interno, espessura da parede de $3,17 \mathrm{~mm}$ (1/8") e alturas (médias) conforme indicado na tabela 3. 
Tab. 3 - dimensões das peças utilizadas no procedimento de compactação

\begin{tabular}{ccc}
\hline Peça & Altura $(\mathbf{c m})$ & Volume $\left(\mathbf{c m}^{3}\right)$ \\
\hline Cilindros & 8,0235 & 307,46 \\
Anéis & 3,0423 & 116,58 \\
"Cabeça" & 16,3 & 624,61 \\
\hline
\end{tabular}

O conjunto "cabeça + anel (ou cilindro)", devidamente travado, substitui a proveta na norma anteriormente referida; do mesmo modo, como "caixa de compactação" utilizou-se um tubo, também de alumínio, de 5" de diâmetro interno e $45 \mathrm{~cm}$ de altura, suficiente para encamisar o conjunto de compactação e servir de "guia" ao movimento de queda (foto 8). A compactação foi promovida pela elevação manual do conjunto, por um sistema de fios, até que tocasse num ressalto na extremidade superior do tubo; o conjunto, então, era solto para atingir, em queda livre, um substrato de madeira.

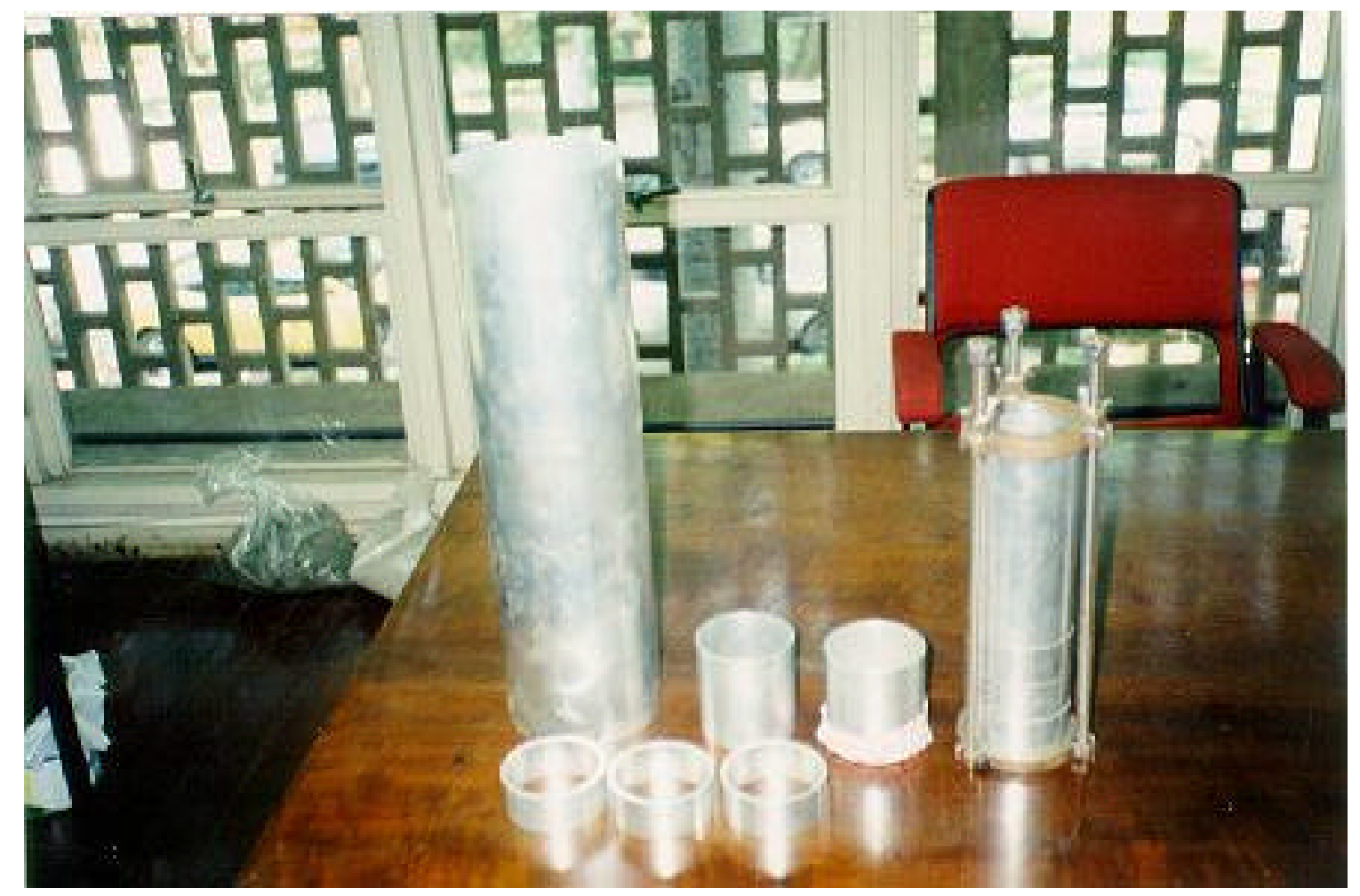

Foto 8 - conjunto de compactação montado, ao lado dos cilindros, anéis e do tubo guia

Este procedimento foi utilizado no preparo das amostras submetidas aos ensaios de porosidade e condutividade hidráulica, realizados em equipamentos 
que necessitam dos anéis e cilindros, respectivamente, nas dimensões acima referidas, conforme discutido adiante.

As amostras de solo, com adições de turfa em 4 proporções, destinadas aos ensaios físicos, foram submetidas a idênticas condições de compactação (incluindo o "branco").

O conjunto utilizado para compactar amostras destinadas aos ensaios para determinação de porosidade é constituído por um anel, na base, sobreposto por um cilindro mais a cabeça, perfazendo uma coluna total de $270 \mathrm{~mm}$ de altura; a altura de queda foi, portanto, de $180 \mathrm{~mm}$.

Já para a compactação das amostras destinadas à determinação da condutividade hidráulica, a posição do anel e cilindro foi invertida.

Após a realização dos movimentos de queda, a peça (cilindro ou anel), posicionada na parte inferior do conjunto e contendo o material de interesse aos ensaios, foi separada do restante do conjunto com o auxílio de uma fina lâmina de aço.

\subsection{ENSAIOS FísICOS}

Sob esta denominação estão aqui incluídas as determinações de massa específica aparente, o estudo da distribuição de tamanho dos poros, com determinação de macro, meso e microporosidades, e da condutividade hidráulica, realizados para as amostras com adição de turfa.

As primeiras amostras compactadas foram submetidas a ensaios de porosidade e condutividade hidráulica e, conforme preconizado na norma BS1460 de referência, o número de quedas inicialmente impingido a cada amostra foi 50. Entretanto, os resultados analíticos não apresentaram sensibilidade, ou seja, não houve contraste que pudesse indicar influência da adição de turfa às amostras (resultados muito próximos e sem demonstrar qualquer tendência).

Assim, relativamente a esta condição de compactação das amostras, o único dado aproveitado, a que será feita referência nos capítulos seguintes, foi a densidade aparente (e a porosidade total dela derivada). 
Dentro de um procedimento de aferição para a melhor conformação das amostras, as compactações foram repetidas para duas outras condições menos rigorosas: 15 e 5 movimentos de queda.

As amostras conformadas nestas condições foram submetidas aos ensaios de retenção de água (câmaras e funis); a análise dos resultados obtidos nesta etapa conduziu à priorização da condição menos rigorosa (5 movimentos de queda) para a execução dos ensaios de condutividade hidráulica.

\subsubsection{Densidade aparente}

É a relação entre a massa da amostra de solo e o seu volume, incluindo os espaços ocupados por ar e água. Pode ocorrer variação nos seus valores para igual classe de solo, devido ao fenômeno da compactação ou adensamento provocado pelo uso e ocupação.

Assim definida e tendo em vista a manipulação a que foram submetidas as amostras pela incorporação de turfa, sua determinação foi baseada no método de compactação acima referido.

A densidade aparente compactada $\left(\rho_{\mathrm{b}}\right), \mathrm{em} \mathrm{g} / \mathrm{cm}^{3}$, é dada por:

$$
\rho_{\mathrm{b}}=\frac{\text { massa da amostra seca a } 105^{\circ} \mathrm{C}}{\text { volume ocupado no cilindro }}
$$

\subsubsection{Porosidade}

A estrutura do solo tem relação intrínseca com suas propriedades físicas, especialmente com as relativas à retenção e transporte de soluções, gases e calor.

A porosidade é um dos mais significativos parâmetros para se definir a estrutura de um espaço poroso e, principalmente, sua capacidade em armazenar e distribuir água.

Segundo DANIELSON \& SUTHERLAND (1987), na matriz do solo há um arranjo complexo de cavidades inter e intra-agregados que variam em 
quantidade, tamanho, forma, distribuição, sinuosidade e continuidade sendo a quantificação precisa destas características tarefa praticamente impossível. Entretanto, o espaço poroso total pode ser determinado com relativa precisão e, assumindo-se certas generalizações, também a distribuição do tamanho dos poros.

\subsubsection{Porosidade total}

É definida como o volume total do espaço existente nos interstícios entre os grãos constitutivos do solo, ocupados normalmente por ar e água.

Sua determinação foi realizada por dois métodos: por densidades e por umidade a volume.

- pelo primeiro método, considerou-se a densidade aparente $\left(\rho_{b}\right)$ e a de partículas $\left(\rho_{p}\right)$. Como $\rho_{b}$ é sempre menor que $\rho_{p}$ em amostras secas, apenas parte do volume aparente (ou volume total) da amostra seca é ocupado por partículas sólidas, sendo o remanescente ocupado por material mais leve (ar). Desta forma, o quociente $V_{p} / V_{b}$, onde $V_{p}=$ volume das partículas e $V_{b}=$ volume total, é a fração do volume total da amostra ocupado exclusivamente pelos sólidos. Lembrando que $m_{s}=\rho_{p} \cdot V_{p}=\rho_{b} \cdot V_{b}$, segue-se que:

$$
\frac{\mathrm{V}_{\mathrm{p}}}{\mathrm{V}_{\mathrm{b}}}=\frac{\rho_{\mathrm{b}}}{\rho_{\mathrm{p}}}
$$

A porosidade total $S_{t}$ é definida como a porcentagem do volume total não ocupada por sólidos, isto é,

$$
S_{t}=\left(1-\rho_{b} / \rho_{p}\right) \times 100
$$

- por umidade a volume considerou-se o quociente entre o volume de água contido na amostra (após saturação) pelo volume da amostra $\left(\mathrm{cm}^{3} / \mathrm{cm}^{3}\right)$. Na prática, o volume de água presente na amostra é tomado como massa, já que a densidade da água é considerada como igual a $1 \mathrm{~g} / \mathrm{cm}^{3}$. Assim, 


$$
S_{t}=\left(m_{u}-m_{s}\right) / V \times 100
$$

Entretanto, a simples determinação da porosidade total para a caracterização do sistema de poros não é relevante, pois apenas poros acima de determinado diâmetro permitem drenagem e aeração (BONNEAU \& LEVY, 1982). É desejável conhecer-se a distribuição do tamanho dos poros ou o volume ocupado pelos poros maiores, valor este de maior significado quando se pretende investigar o movimento e armazenamento de água e gases, a resistência dos solos, o desenvolvimento do sistema de raízes pela planta e problemas envolvendo fluxo e retenção de calor.

Estes autores distinguem dois tipos de porosidade:

- microporosidade, também denominada porosidade capilar, como sendo o volume de poros de um solo que retém água após a drenagem por gravidade. O diâmetro dos poros que retém água nestas condições está compreendido entre 3 e $8 \mu \mathrm{m}$;

- macroporosidade: volume de poros que, nas mesmas condições de drenagem, é ocupado apenas por ar.

Desta forma,

$$
\text { Macroporosidade }=\text { porosidade total }- \text { microporosidade } \text {. }
$$

BONNEAU \& LEVY (1982) enfatizam a importância do conceito acima, citando exemplos de solos com estrutura grumosa que chegam a apresentar porosidade total entre 60 e 70\%, com volume de micro e macroporosidade aproximadamente da mesma ordem de grandeza; por outro lado, solos com textura argilosa, que também apresentam $S_{t}$ em torno de $60 \%$, podem ter macroporosidade praticamente nula.

É desejável, pois, para melhor análise do armazenamento de água no solo, conhecer-se a distribuição dos poros quanto ao seu tamanho e quantidade. 


\subsubsection{Distribuição do tamanho dos poros: macro, meso e microporosidade}

A determinação do tamanho e distribuição dos poros no solo pressupõe a aceitação do modelo físico da teoria capilar como representativo do espaço poroso neste meio.

A definição do tamanho dos poros faz-se pela identificação dos diâmetros cilíndricos equivalentes (DANIELSON \& SUTHERLAND, 1987), normalmente estimados a partir da drenagem pela aplicação de tensões capilares a amostras saturadas, pelo método denominado "dessorção de água".

O método consiste na drenagem, por etapas, de uma amostra de solo embebida em água até a saturação por 48 horas, através da aplicação de tensões específicas para drenar o volume de água contido em poros de diâmetro equivalente; pelas etapas sucessivas do ensaio pode-se determinar a distribuição do tamanho dos poros na amostra. Pelo modelo proposto, estes autores pressupõem que os poros maiores são os primeiros a serem drenados, seguidos de poros sucessivamente menores.

REICHARDT (1985) define como potencial matricial $\left(\psi_{\mathrm{m}}\right)$ a energia resultante de forças capilares e de adsorção atuantes no solo devido à interação entre a água e as partículas sólidas, na sua matriz. Os fenômenos capilares resultam da tensão superficial da água e de seu ângulo de contato com as partículas sólidas.

Segundo este autor, em superfícies curvilíneas de interface líquido-gás existe uma diferença de pressão entre pontos imediatamente superiores e inferiores à interface, responsável por uma série de fenômenos capilares. Esta diferença de pressão $(\Delta \mathrm{P})$ é expressa por:

$$
\Delta P=\frac{2 \cdot \sigma}{R}
$$

onde: $\sigma$ é a tensão superficial do líquido;

$\mathrm{R}$ é o raio de curvatura do menisco na interface líquido-gás. 
Esta relação é conhecida como "Fórmula de Laplace", válida para superfícies esféricas, cuja dedução pode ser encontrada no capítulo introdutório de LIBARDI (1995).

$\mathrm{R}$ é o resultado do ângulo $\alpha$ de contato entre as paredes do tubo e o líquido, sendo $\alpha$ formado pela superfície do sólido e a tangente da interface curvilínea líquido-gás (figura 6).

Ainda conforme REICHARDT (1985), a curvatura do menisco será tanto maior quanto menor o diâmetro do capilar. Se o raio de curvatura do menisco $R$ for igual ao raio do tubo capilar $r$, o menisco será hemisférico e o ângulo $\alpha$ de contato, nulo. Para $\alpha$ compreendido entre $0^{\circ}$ e $90^{\circ}, \mathrm{R}=\mathrm{r} / \cos \alpha$ e a equação (I) pode ser escrita como:

$$
\Delta P=\frac{2 \cdot \sigma \cdot \cos \alpha}{r}
$$

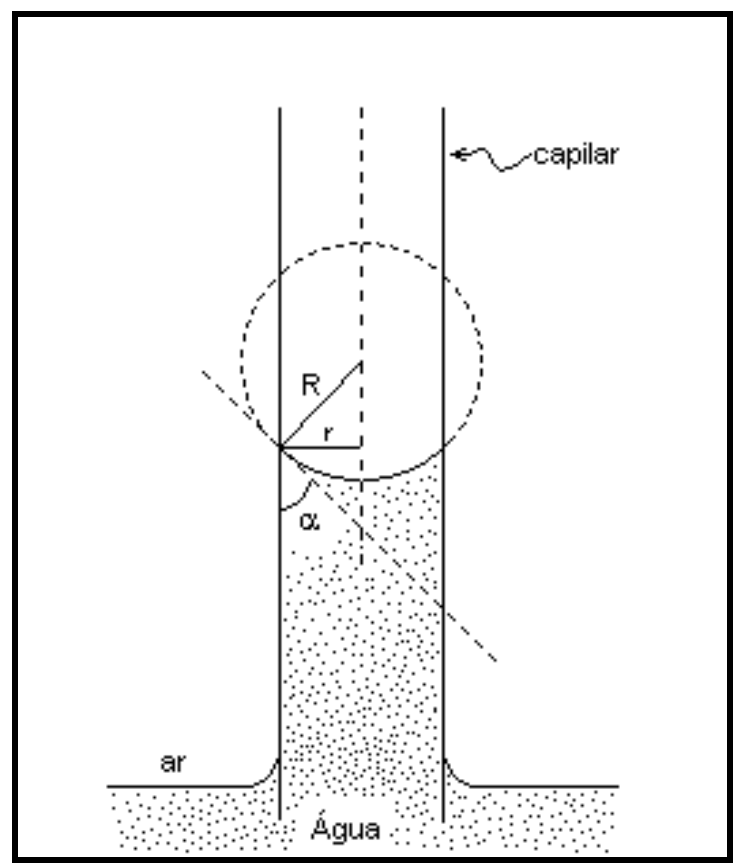

Fig. 6 - capilar imerso em água (REICHARDT, 1985)

REICHARDT (1985) afirma que o ângulo de contato de um líquido sobre um sólido é geralmente constante em dadas condições físicas. O ângulo de contato para a água pura sobre superfícies planas, inorgânicas, é geralmente próximo de zero, o que conduz $\underline{\cos \alpha}$ à unidade na equação (II); o autor 
ressalta, entretanto, que rugosidades ou impurezas adsorvidas pela superfície podem fazer $\alpha$ diferir de zero.

Da Hidrostática tem-se que $P=\rho \cdot g \cdot h \quad$ e, portanto:

$$
\frac{2 \cdot \sigma}{r}=\rho \cdot g \cdot h
$$

Assim, num tubo capilar de vidro, o raio do tubo será:

$$
r=\frac{2 \cdot \sigma}{\rho \cdot g \cdot h}
$$

Na teoria capilar, $h$ representa a altura de ascensão capilar promovida pelas forças de adesão entre as paredes do sólido e o líquido, sendo inversamente proporcional ao raio do tubo capilar (LIBARDI, 1995).

Na prática, $h$ representa, no solo, a energia com que a água se encontra retida no espaço poroso, ou seja, o potencial matricial $\psi_{m}$ (REICHARDT, 1985).

Assim, a submissão de uma amostra saturada a determinada tensão de sucção, provoca drenagem dos poros de diâmetro equivalente $d_{p}$ igual a:

$$
d_{p}=\frac{4 \cdot \sigma}{\rho \cdot g \cdot h}
$$

onde: $\quad d_{p}=$ diâmetro do poro $(\mu \mathrm{m})$;

$\sigma=$ tensão superficial da água $\left(\mathrm{J} / \mathrm{m}^{2}\right)$;

$\rho=$ densidade da água $\left(\mathrm{kg} / \mathrm{m}^{3}\right)$;

$\mathrm{g}=$ aceleração da gravidade $\left(\mathrm{m} / \mathrm{s}^{2}\right) ; \mathrm{e}$

$\mathrm{h}=$ potencial matricial $\left(\mathrm{cm} \mathrm{de} \mathrm{H}_{2} \mathrm{O}\right)$.

Considerando-se os seguintes valores para a igualdade acima:

$$
\begin{aligned}
& \sigma=7,244 \times 10^{-2} \mathrm{~J} / \mathrm{m}^{2} \\
& \rho=1.000 \mathrm{Kg} / \mathrm{m}^{3} \\
& g=9,8 \mathrm{~m} / \mathrm{s}^{2}
\end{aligned}
$$


$(4 . \sigma / \rho . g) \cong 3000$ para a água, e a equação ( IV ) pode ser reescrita como:

$$
d_{p}=3000 / h
$$

No estudo da distribuição dos poros, Koorevaar (1983 apud LIBARDI, 1995) adota a seguinte classificação:

- macroporos: responsáveis pela aeração e escoamento d'água no solo, são poros maiores que $100 \mu \mathrm{m}$, onde, pela equação acima, o valor $30 \mathrm{~cm} \mathrm{H}_{2} \mathrm{O}$ de sucção para $h$ é o suficiente para remover a água contida nestes poros;

- mesoporos: aqueles com diâmetro compreendido entre 30 e 100 $10 \mathrm{~m}$, responsáveis pela distribuição da água no espaço poroso; e

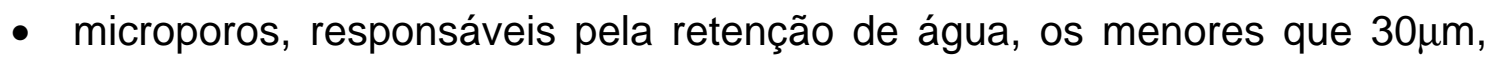
cujo limite refere-se à tensão de $100 \mathrm{~cm} \mathrm{H}_{2} \mathrm{O}$ na equação ( IV ).

O ensaio de retenção de água no solo consiste em calcular a umidade através do registro do peso da amostra após constatado o equilíbrio hidrostático entre a água retida nos poros do solo e a tensão de sucção.

Da aplicação de diferentes tensões numa mesma amostra, obtêm-se as umidades equivalentes, o que permite a elaboração da "curva característica da umidade do solo" (REICHARDT, 1985) ou, simplesmente, "curva de retenção", relacionando a energia potencial matricial $\left(\psi_{\mathrm{m}}\right)$, representada pelas tensões de sucção empregadas, ao conteúdo de água correspondente.

A figura 7 (LIBARDI, 1995) ilustra o procedimento de medida da umidade da amostra através do funil de Haines (funil munido de uma placa porosa na parte inferior de seu corpo) adaptado a uma haste flexível. Em (a) tem-se a saturação da amostra de solo, onde deve ser garantido o mais perfeito contato entre a amostra e a placa; em (b), a aplicação da tensão de sucção $h$ desejada para drenar poros de diâmetro equivalente (de acordo com a equação IV) do conjunto amostra + placa porosa. 


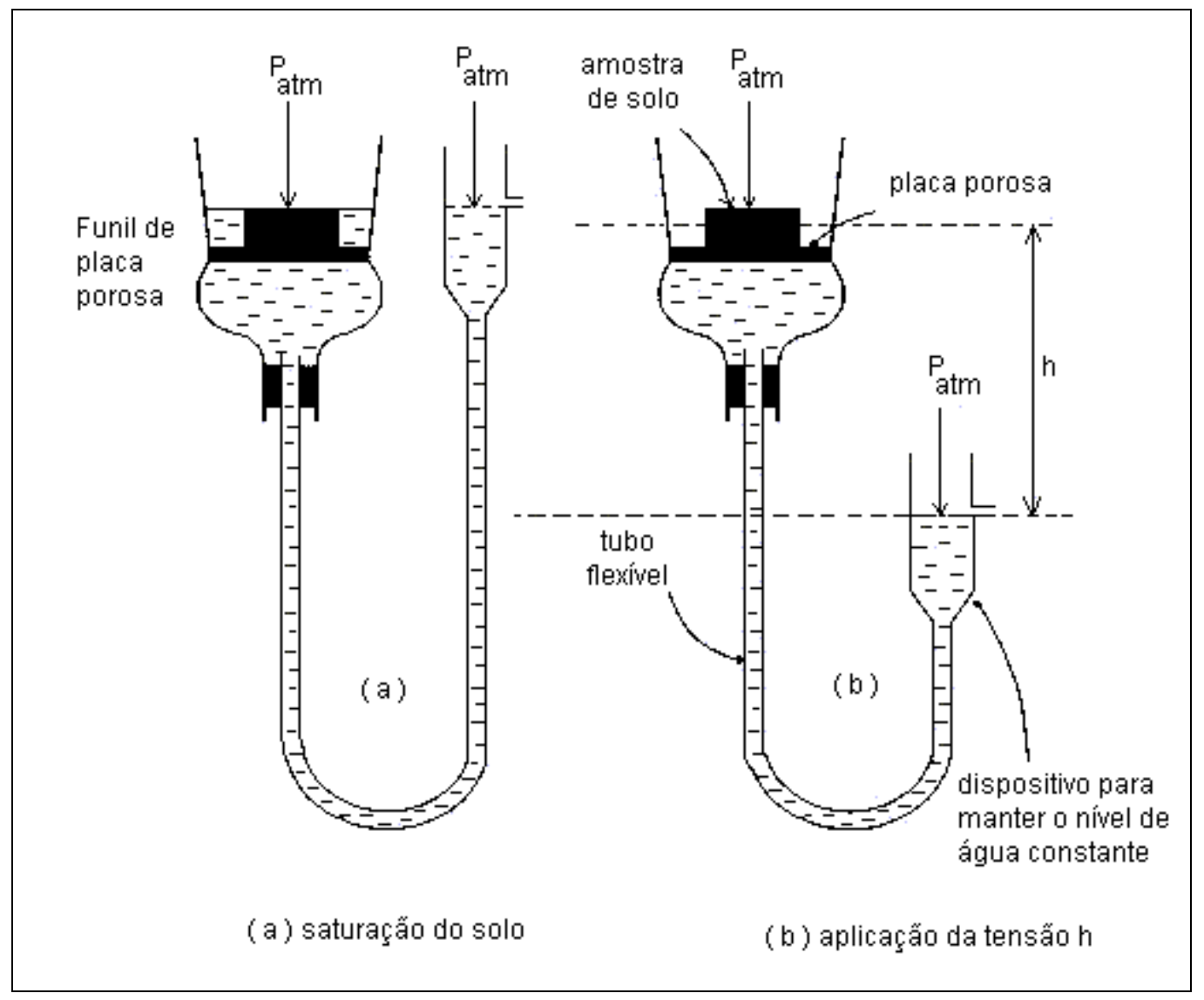

Fig. 7 - esquema ilustrativo do funil de Haines - ensaio de dessorção (mod. de LIBARDI, 1995)

Apenas pontos de baixa tensão da curva são determinados por este procedimento, tendo em vista limitações operacionais (por exemplo, estabelecer tensões de sucção superiores a 1 metro de coluna d'água). Este equipamento utiliza placas porosas de cerâmica com poros de $30 \mu \mathrm{m}$ de diâmetro médio, o que, teoricamente, o habilita a condições operacionais de $h$ até $1 \mathrm{~m}$; entretanto, na prática, tensões de sucção superiores a $80 \mathrm{~cm} \mathrm{H}_{2} \mathrm{O}$ (suficientes para drenagem de poros diâmetro $\cong 37 \mu \mathrm{m}$ ) têm provocado a ruptura de meniscos em alguns poros da placa, o que permite a entrada de ar no sistema e invalida o ensaio. A foto 9 ilustra os equipamentos laboratoriais utilizados nestes ensaios. 


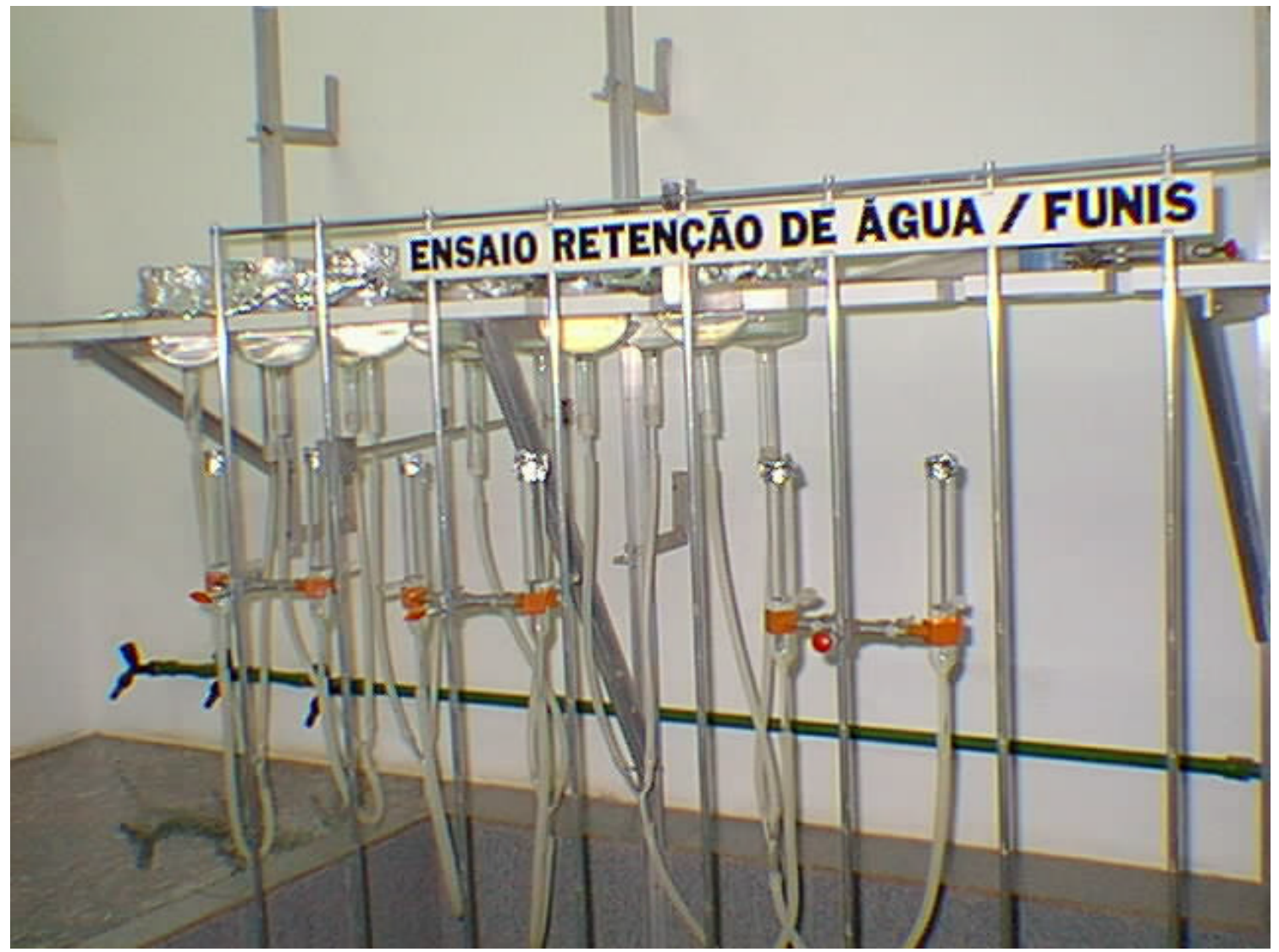

Foto 9 - funis de Haines de placa porosa utilizados no ensaio de dessorção à tensão de sucção de $30 \mathrm{~cm} \mathrm{H}_{2} \mathrm{O}$

Os pontos de média e alta tensão da curva são determinados em câmaras de Richards, conforme método descrito em KLUTE (1987).

A figura 8 (LIBARDI, 1995) e as fotos 10 e 11 ilustram este equipamento, que, basicamente, consiste numa câmara para suportar altas pressões com uma placa cerâmica porosa em seu interior. Seu funcionamento difere do funil quanto à tensão aplicada que, aqui, consiste em pressão de ar, e quanto aos valores envolvidos, que variam entre 100 e $15000 \mathrm{~cm} \mathrm{H}_{2} \mathrm{O}(\cong 0,1 \mathrm{a} 15 \mathrm{~atm})$.

A placa cerâmica, como se pode notar na figura 8 , tem sua face inferior coberta por um diafragma de borracha, selado em sua borda. Entre a placa e 0 diafragma existe uma tela de náilon para permitir o fluxo de solução quando da aplicação da pressão $P$, que faz com que a solução se movimente do solo para o pequeno reservatório sob a placa, gotejando no tubo de saída. O equilíbrio hidrostático é atingido quando não mais houver gotejamento pelo tubo, o que ocorre normalmente após 20 dias do início do ensaio; nesta condição, a amostra é retirada da câmara para a determinação de sua umidade. 


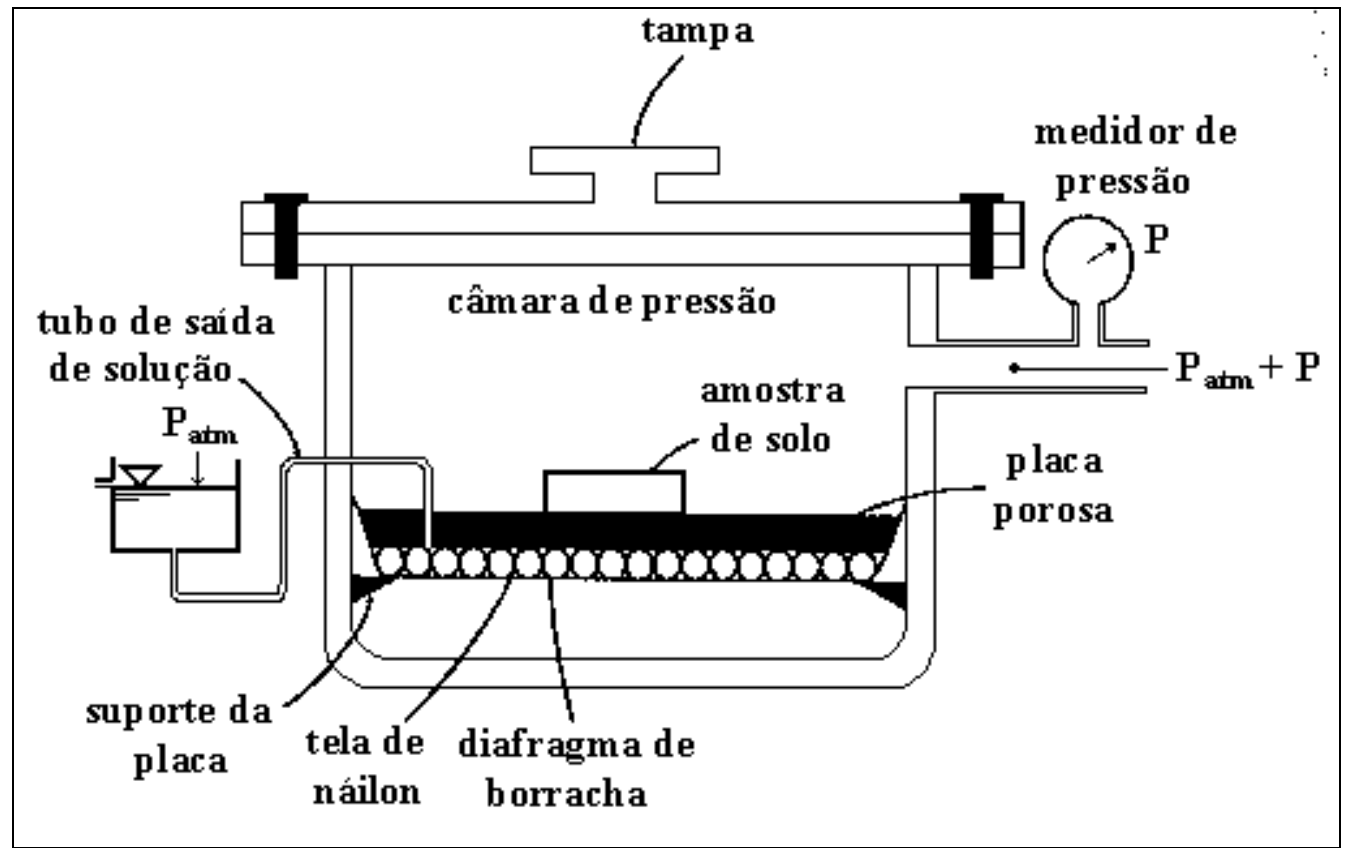

Fig. 8 - câmara de pressão de Richards (mod. de LIBARDI, 1995)

A curva de retenção permite, desta forma, a determinação de quantidades de poros de dimensões variadas, elementos mais representativos que o valor da porosidade total para representar o espaço poroso de um solo. Assim, a incorporação de turfa ao solo, pela agregação promovida nas partículas argilosas, conforme postulado anteriormente, poderá redesenhar o espaço poroso das amostras na direção do aumento da meso e, principalmente, macroporosidade, fato bastante desejável na melhoria das condições físicas de um solo.

As amostras foram ensaiadas a tensões de $30 \mathrm{~cm} \mathrm{H}_{2} \mathrm{O}$ (em funis de placa porosa) e $100 \mathrm{~cm} \mathrm{H}_{2} \mathrm{O}$ (em câmaras de Richards), para delimitação dos valores de macro, meso e microporosidade. A saturação a que foram previamente submetidas, anteriormente referida, foi obtida em placas de Petri por ascensão capilar, através da adição de água, por gotejamento, até a obtenção de uma película d'água à superfície.

Deve-se ressaltar que a amostra utilizada para o ensaio no funil de Haines não foi a mesma utilizada na câmara de Richards, ou seja, foram preparadas 2 alíquotas de cada uma das misturas, destinadas especificamente a cada um destes ensaios. 


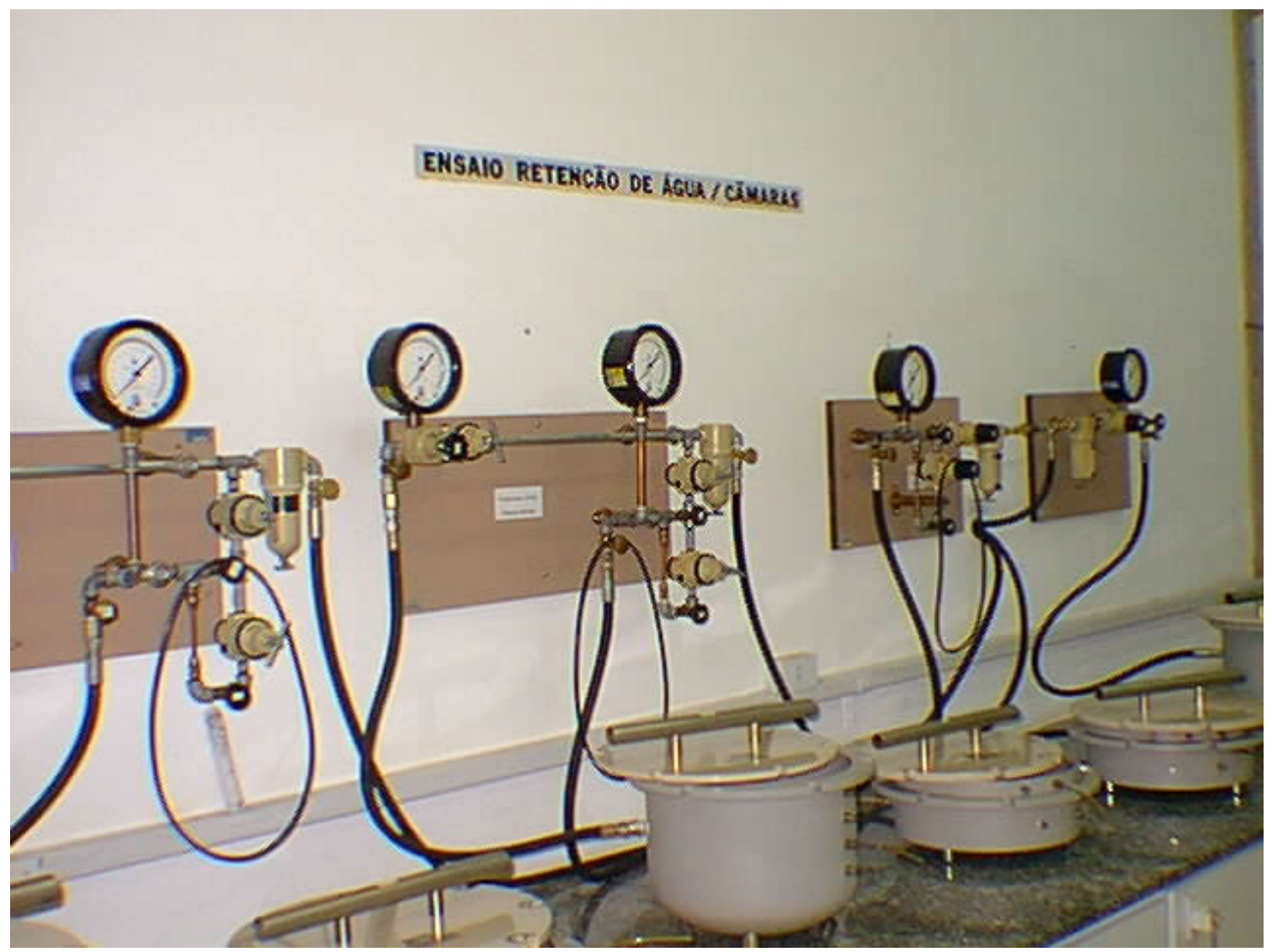

Foto 10 - câmaras de Richards utilizadas na dessaturação de amostras de solo a tensões superiores a $100 \mathrm{~cm} \mathrm{H}_{2} \mathrm{O}$; os modelos de menor tamanho são dimensionados para suportar pressões maiores

Nestes ensaios foram utilizados os "anéis", anteriormente referidos, por uma questão de adaptação aos equipamentos laboratoriais.

\subsubsection{Condutividade hidráulica}

A água move-se através do solo em resposta a várias forças que atuam sobre ela.

A condutividade hidráulica, juntamente com a retenção de água, é um parâmetro que determina o comportamento do sistema de escoamento de água no solo.

O grau de permeabilidade é numericamente expresso pelo "coeficiente de permeabilidade" ( $\left.k_{p}\right)$, ou condutividade hidráulica (KLUTE \& DIRKSEN, 1987) e sua determinação é feita tendo em vista a lei experimental de Darcy, 
estabelecida estatisticamente em 1856 (CURY, 1953), onde a velocidade de percolação é diretamente proporcional ao gradiente hidráulico (figura 9).

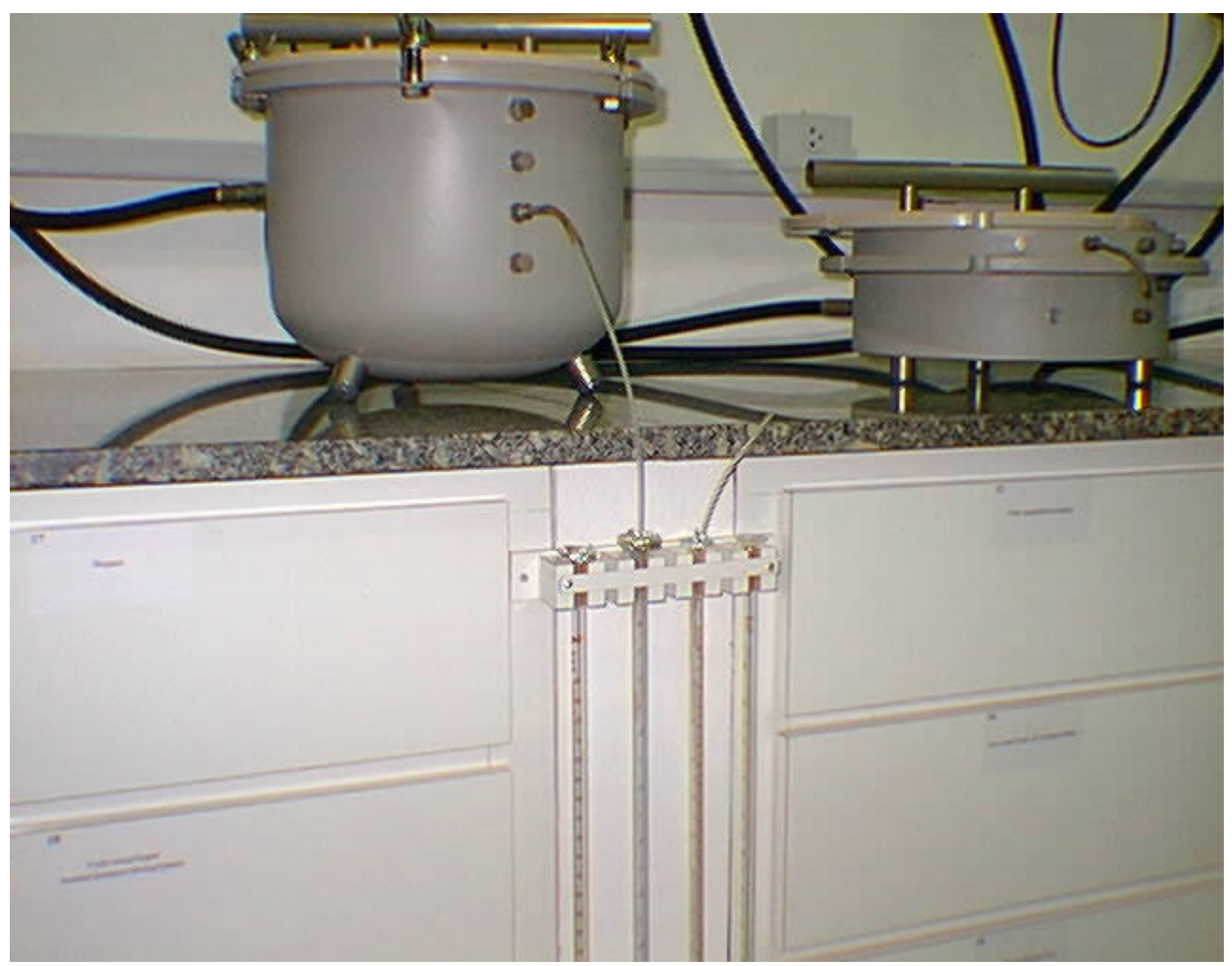

Foto 11 - detalhe da câmara salientando o tubo de saída d'água

A Lei de Darcy é expressa por: $V_{p}=k_{p} x i$, onde:

$V_{p}=$ velocidade real de percolação d'água;

$\mathrm{K}_{\mathrm{p}}=$ coeficiente de percolação, que é a velocidade real média do escoamento através dos vazios do solo, quando $\mathrm{i}=1$;

$\mathrm{i}=$ gradiente hidráulico $=\mathrm{h} / \mathrm{L}$;

$\mathrm{h}=$ diferença entre os níveis d'água sobre cada um dos lados da camada de solo ou, em outras palavras, a perda de carga sobre a distância L;

$\mathrm{L}=$ espessura da camada de solo, medida na direção do escoamento. 


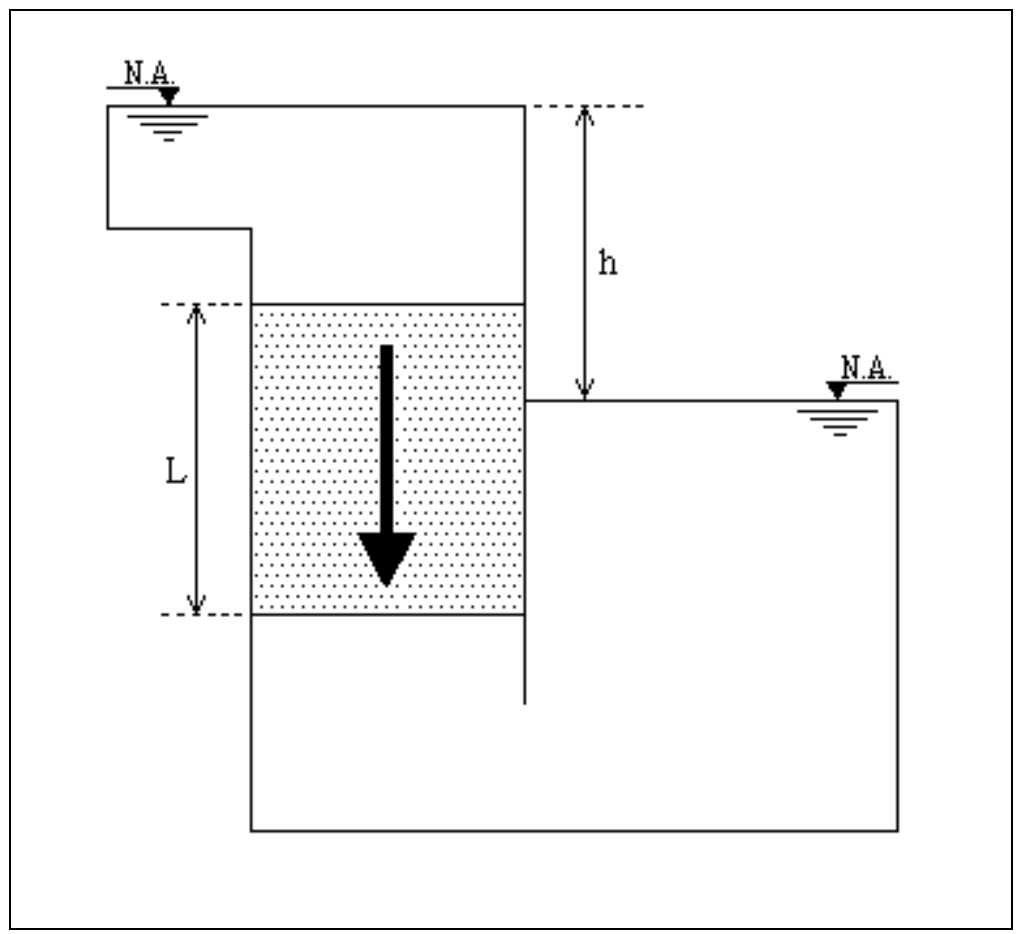

Fig. 9 - esquema ilustrativo da Lei de Darcy (CURY, 1953)

A permeabilidade de um solo é influenciada pela granulometria de seus constituintes, viscosidade da água (por sua vez, função de sua temperatura, concentração de sais, etc.), do índice de vazios, da forma e disposição dos poros e do grau de saturação do solo (CURY, 1953).

A determinação é feita a partir da aplicação de uma carga hidráulica constante em uma amostra de solo. Os poros maiores são os primeiros a serem drenados; à medida que a drenagem se processa, pode aumentar a sinuosidade do caminho a ser percorrido pela água. Estes e outros fatores contribuem a uma rápida diminuição na condutividade com o decréscimo da umidade, podendo chegar a níveis 100 a 1000 vezes menores que seu valor no ponto de saturação da amostra (KLUTE, 1979).

Os ensaios foram realizados pelo método de aplicação de carga hidráulica constante.

A extensão da Lei de Darcy para solos insaturados pode ser escrita como:

$$
\mathrm{F}=-\mathrm{k}(\theta) \cdot \nabla \mathrm{H}
$$


onde: $F=$ densidade de fluxo;

$\nabla \mathrm{H}=$ valor negativo do gradiente de potencial da carga hidráulica $\mathrm{H}$; e $\mathrm{K}(\theta)=$ condutividade hidráulica, função do teor de umidade da amostra.

O método consiste na leitura do volume de água que atravessa o solo em um período determinado de tempo, após a imposição de carga hidráulica na amostra. Em laboratório, as amostras são preparadas e saturadas por capilaridade por 48 horas, até sua superfície superior apresentar sinais de completa saturação (filme de água em toda a área da amostra). Obtida a saturação, a amostra é submetida a uma carga hidráulica $(\nabla \mathrm{H})$ durante 24 horas quando, então, é medido o volume de água (V) que passou pela amostra durante 30 minutos.

O cálculo é realizado através da seguinte equação:

$K(\theta)=\frac{V \cdot L}{A \cdot t \cdot H}$

$$
\text { onde: } \quad \begin{aligned}
A & =\text { Área transversal ao fluxo }\left(\mathrm{cm}^{2}\right) ; \\
L & =\text { comprimento da amostra }(\mathrm{cm}) ; \\
H & =\text { carga hidráulica }(\mathrm{cm}) ; \\
V & =\text { volume de água coletado }\left(\mathrm{cm}^{3}\right) ; \text { e } \\
t & =\text { tempo de coleta da água }(\mathrm{h}) .
\end{aligned}
$$

A realização deste ensaio também pressupõe a submissão prévia das amostras àquele procedimento de compactação, utilizando-se o cilindro de $80 \mathrm{~mm}$ de altura; para sua execução, outro cilindro idêntico lhe é sobreposto para servir de reservatório à água responsável pelo estabelecimento da carga hidráulica; é esquematicamente ilustrado na figura 10.

Em laboratório, o frasco (ou bureta) de Mariotte (dispositivo utilizado para ajuste e manutenção de nível d'água) é substituído por um tanque com nível d'água constante (água corrente e recirculada) que alimenta os vários cilindros pelo princípio dos vasos comunicantes, mantendo a carga hidráulica desejada (foto 12). 


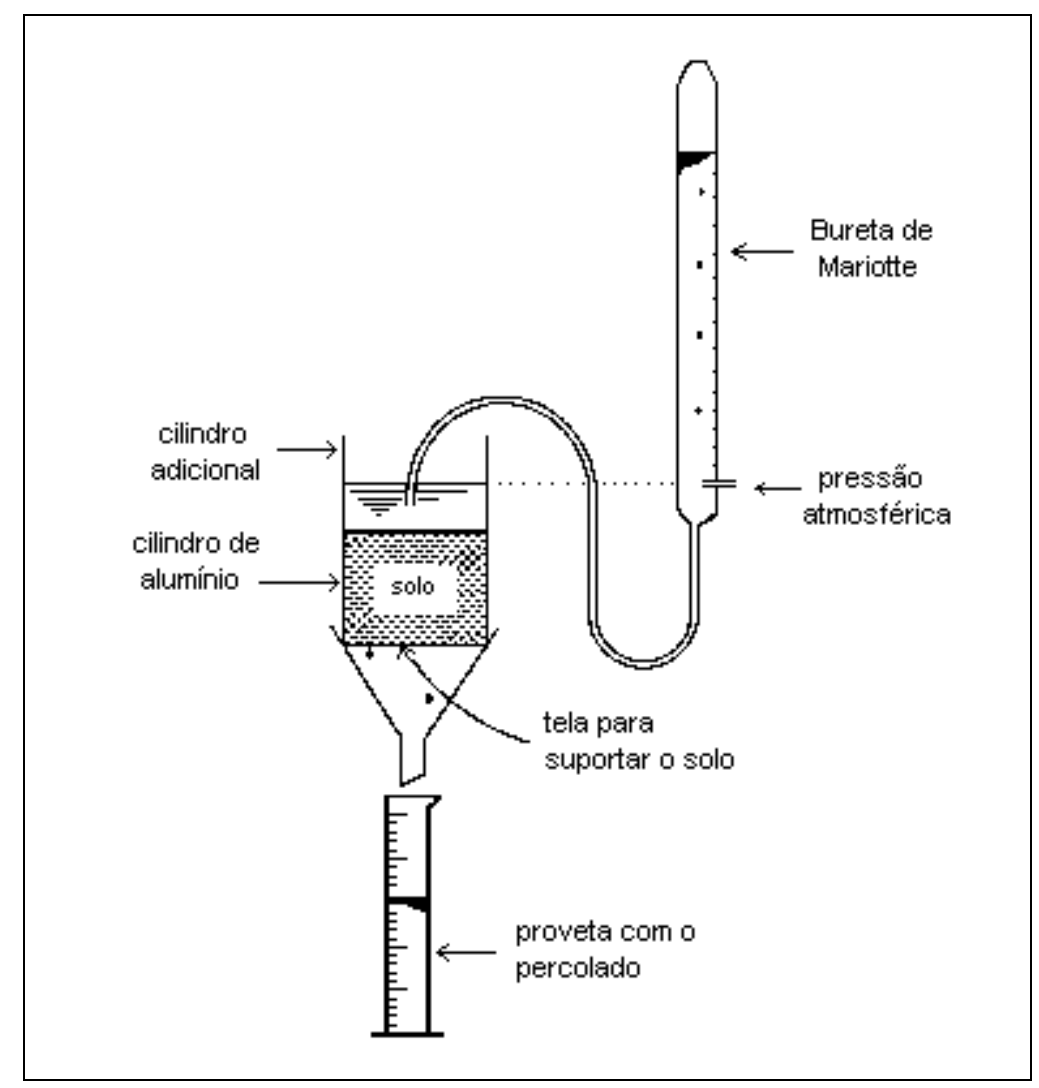

Fig. 10 - diagrama do sistema de carga constante para medida da condutividade (mod. de LIBARDI, 1995)

\subsection{ENSAIOS QUÍMICOS}

Sob esta denominação estão aqui incluídos os estudos do efeito tampão e da retenção de cátions propiciados pela adição de turfa.

\subsubsection{Efeito tampão}

Pode ser definido como a resistência que o solo apresenta contra modificações químicas ou de $\mathrm{pH}$ bruscas do meio.

Solos com bom poder de tamponamento têm atenuados, ou mesmo evitados, choques violentos e desequilíbrios minerais promovidos por calagem 
e/ou adubação incontroladas sobre a microvida edáfica e o metabolismo das plantas.

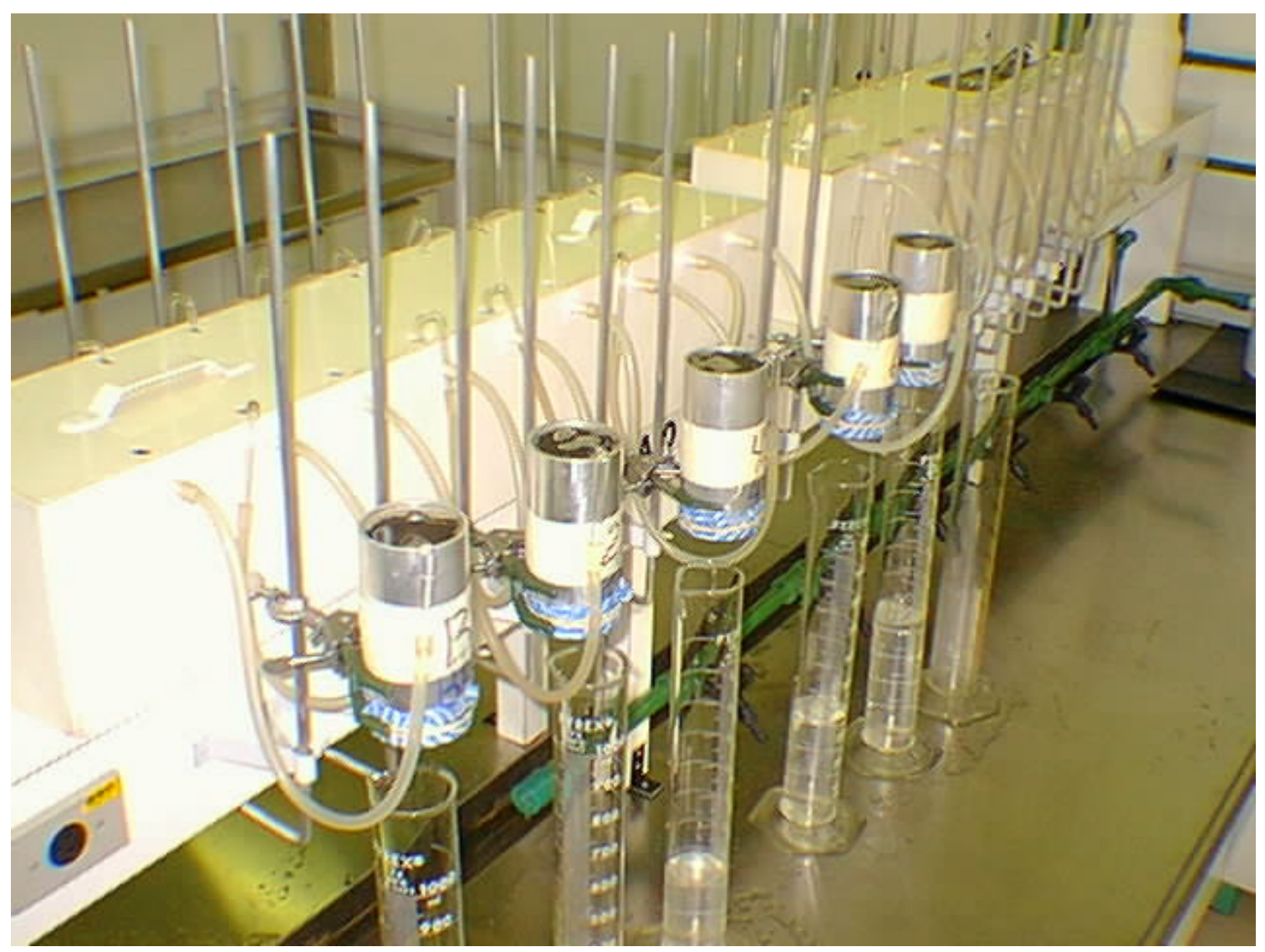

Foto 12 - aparato laboratorial utilizado nos ensaios para determinação da condutividade hidráulica

Segundo PRIMAVESI (1984), a importância de se evitarem tais fatos reside - por um lado - na preservação do equilíbrio ecológico necessário à cadeia alimentar dos seres que povoam os solos, cujo controle é ditado, de modo genérico, por mecanismos de predação dos seres de energia inferior pelos de concentração energética superior. A alteração do $\mathrm{pH}$ do meio pode constituir séria adversidade à existência de determinados tipos de vida (especialmente à microvida) do solo e levar ao estabelecimento de condições de exceção - a proliferação de espécies capazes de suportar as condições adversas e que podem se tornar pragas pelo simples fato de não mais haver inimigos naturais. 
Para a mesma autora - por outro lado - grande parte da absorção de nutrientes e, principalmente, água pela planta se dá no solo, na zona das raízes, através de mecanismos predominantemente osmóticos, onde o trânsito de soluções se faz, em situação normal e em planta sadia, a partir da "solução do solo", meio com menor concentração de eletrólitos (menor pressão osmótica) em direção à raiz, de concentração mais elevada (maior pressão osmótica). Adubação excessiva, situação mais corriqueira do que se possa imaginar, pode conduzir a um enriquecimento da "solução do solo" e à conseqüente inversão do fluxo osmótico ideal, que passaria, assim, a ser realizado das micelas radiculares em direção ao solo. A matéria orgânica na forma humificada pode formar quelatos com os elementos presentes nos fertilizantes, convertendo-os a forma não solúvel e atenuando os efeitos das possíveis variações de $\mathrm{pH}$ do meio.

O estudo do efeito tampão foi conduzido pela adição, às misturas solo+turfa, de substâncias modificadoras do $\mathrm{pH}$, em proporções variadas.

Utilizaram-se, de forma individualizada, um calcário dolomítico comercializado sob a marca "MINERCAL Agrícola Faixa D", proveniente de Votorantim (SP), produzido pela Mineração Pagliato, com especificações constantes da tabela 4, e soda cáustica (NaOH) P.A., padrão MERCK.

Tab. 4 - características do calcário dolomítico utilizado no estudo do efeito tampão

\begin{aligned} & \hline Característica $(\%) \\ & \mathrm{CaO}=39 \% \\ & \mathrm{MgO}=13 \% \\ & \mathrm{PRNT}=91 \% \\ &$ passante \#10 ABNT $(2 \mathrm{~mm})=100 \% \\ &$ passante \#20 ABNT $(0,84 \mathrm{~mm})=93 \% \\ &$ passante \#50 ABNT $(0,3 \mathrm{~mm})=80 \% \\ &$\hline\end{aligned}

O calcário dolomítico foi adicionado às misturas em 12 proporções, variáveis de 0 a $20 \%$ em peso e referíveis à massa seca das amostras. Previamente à determinação do $\mathrm{pH}$, pelo método anteriormente referido, as 
amostras ficaram armazenadas por um período de 30 dias, acondicionadas em sacos plásticos.

A subdivisão deste estudo contemplando a utilização de $\mathrm{NaOH}$ foi realizada através da preparação de 3 soluções diluídas desta substância (0,22g/l, 1,02g/l e 2,90g/l). Sugerido pela metodologia de BRASIL (1997), cada uma destas soluções foi adicionada às amostras na proporção de $25 \mathrm{ml}$ para $10 \mathrm{~g}$ para a determinação de $\mathrm{pH}$; as amostras, após agitação com bastão de vidro, foram deixadas em repouso por 3 horas e novamente agitadas, previamente à leitura do $\mathrm{pH}$.

O equipamento utilizado foi um pHmetro marca HANNA, modelo HI9321, calibrado para leitura na faixa alcalina (com soluções padrão pH 7 e pH 10); a calibração com soluções padrão pH 4 e pH 7, conforme preconizado pelo método, foi feita apenas para determinação do pH das misturas sem a adição das substâncias alcalinas, uma vez que, sabidamente, o $\mathrm{pH}$ da maioria dos solos nacionais é ligeiramente ácido.

\subsubsection{Capacidade de Troca de Cátions}

O poder de retenção e troca de cátions é uma característica altamente desejável aos solos agrícolas, e sua medida pode ser expressa pela CTC do solo. Solos com boa capacidade de retenção de cátions são aqueles providos de determinadas espécies de argilominerais, notadamente aquelas pertencentes ao grupo das esmectitas, além de teores adequados de matéria orgânica.

Desta forma, o aumento da CTC em solos pode ser conseguido pela adição de matéria orgânica, principalmente na forma humificada.

O estudo do possível incremento nesta propriedade foi feito pela aditivação das misturas com uma solução policatiônica, preparada a partir de um fertilizante granulado comercial denominado "Peters Excel Miracle Gro Professional 15-5-15". A composição química fornecida pelo fabricante é referível a $100 \mathrm{mg} / \mathrm{Kg}$ de nitrogênio total, o que corresponde à diluição de 0,67 gramas do fertilizante por litro d'água. A solução estoque foi preparada à razão 
de 268g/l (o limite de solubilidade indicado é de $360 \mathrm{~g} / \mathrm{l}$ ), fornecendo, teoricamente, os valores apresentados na tabela 5.

Tab. 5 - composição química da solução estoque

\begin{tabular}{cccc}
\hline \multicolumn{2}{c}{ Constituinte } & Solução de 100 $\mathbf{m g} / \mathbf{K g ~ N}$ & Solução estoque (mg/Kg) \\
\hline $\mathrm{N}$ & $\left(\mathrm{NH}_{4}\right)$ & 8,00 & 3200 \\
$\mathrm{~N}$ & $\left(\mathrm{NO}_{3}\right)$ & 78,30 & 31.320 \\
$\mathrm{~N}$ & (uréia) & 13,70 & 5.480 \\
& $\mathrm{P}$ & 14,50 & 5.800 \\
$\mathrm{~K}$ & 83,00 & 33.200 \\
$\mathrm{Ca}$ & 33,30 & 13.320 \\
$\mathrm{Mg}$ & 13,33 & 5.332 \\
$\mathrm{~B}$ & 0,10 & 40 \\
$\mathrm{Cu}$ & 0,05 & 19 \\
$\mathrm{Fe}$ & 0,50 & 200 \\
$\mathrm{Mn}$ & 0,25 & 99 \\
$\mathrm{Mo}$ & 0,05 & 19 \\
$\mathrm{Zn}$ & 0,30 & 120 \\
\hline
\end{tabular}

A $100 \mathrm{~g}$ de cada uma das misturas foram adicionados $400 \mathrm{ml}$ desta solução estoque preparada; as misturas foram agitadas por 15 minutos em agitador magnético a 300 rpm e deixadas em repouso por um período de 24 horas, findo o qual foram submetidas à agitação nas mesmas condições anteriores, lavagem e filtração, com 1 litro de água destilada, em funil de Büchner.

O estudo da capacidade de retenção de cátions foi efetuado através de análises químicas dos filtrados e de CTC das amostras de solo, após a realização deste procedimento de lavagem e filtração, com a finalidade de avaliar, novamente, se a adição de turfa ao solo, em alguma das proporções utilizadas, obteria melhor resposta quanto a este quesito.

Não se analisaram, nos filtrados, todos os elementos químicos presentes na solução policatiônica em função dos equipamentos disponíveis nos laboratórios do Departamento de Engenharia de Minas da EPUSP; entretanto, sendo a turfa estigmatizada como substância fortemente adsorvente, principalmente de metais, optou-se por rastrear apenas alguns dos elementos da solução policatiônica. 
As análises de CTC foram realizadas segundo método já referido (BRASIL, 1997); as análises químicas dos filtrados, por colorimetria para $\mathrm{P}$ e por Espectrofotometria de Absorção Atômica (AAS) para K, Zn, Fe, Cu, Mn, Ca e Mg, cujos princípios, extraídos de RATTI (1994), são sinteticamente descritos a seguir.

\subsubsection{Análise química por espectrofotometria de absorção atômica}

As análises químicas por AAS para amostras em solução compreendem processos de nebulização e vaporização da solução, atomização e excitação dos elementos por uma fonte de energia (chama), convertendo-os ao estado fundamental e, posteriormente, à forma de cátions.

Segue-se nova excitação por outra fonte de energia do sistema - um feixe de luz emitido por uma lâmpada de cátodo oco, cuja constituição é a do mesmo metal que se quer analisar e, portanto, de comprimento de onda $(\lambda)$ idêntico aos permitidos ao elemento de interesse. De forma análoga à excitação pela chama, o átomo absorve esta energia que pode ser medida por um detetor colocado no percurso do feixe; este detetor "lê" a quantidade de energia emitida pela lâmpada (em unidades de transmitância) ao ser aspirada somente água pelo equipamento.

Quando átomos do elemento a ser dosado chegam à chama e "roubam" energia do feixe de luz, o detetor acusa menor recebimento de energia, indicando que ocorreu absorção proporcional à quantidade de átomos presentes, podendo-se, assim, quantificar o elemento. A absorção medida, em unidades de absorbância, guarda correlação praticamente linear com a concentração do elemento em solução. Assim, o equipamento pode ser calibrado com soluções de teores conhecidos, obtendo-se uma reta para pequenas faixas de concentrações. O teor dos elementos em amostras desconhecidas é obtido por interpolação gráfica. 


\section{RESULTADOS}

\subsection{Caracterização do SOLO}

\subsubsection{Umidade}

Foram os seguintes os resultados obtidos para a umidade do solo:

Base seca: $\mathrm{H}_{\mathrm{s}}=7,86 \%$

Base úmida: $\mathrm{H}_{\mathrm{u}}=7,29 \%$

\subsubsection{Análise mineralógica por difração de raios-X}

A difração de raios- $X$ acusou a presença dos seguintes minerais na amostra de solo: caolinita, quartzo, microclíneo, albita e biotita, além da possível presença de gibsita e diopsídio.

Apresenta-se nas figuras 11 a 18 a superposição dos padrões difratométricos de cada um destes minerais ao difratograma obtido. 

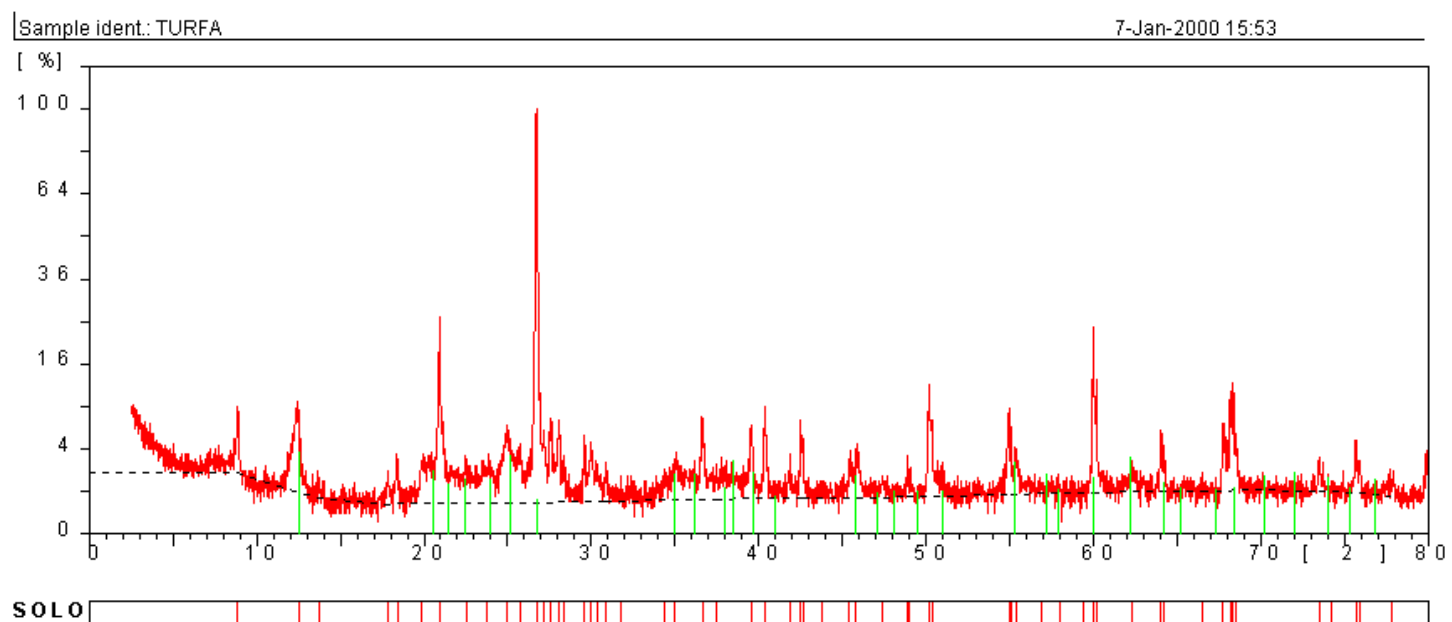
KAOLINITE

Fig. 11 - superposição do padrão difratométrico da caulinita ao difratograma

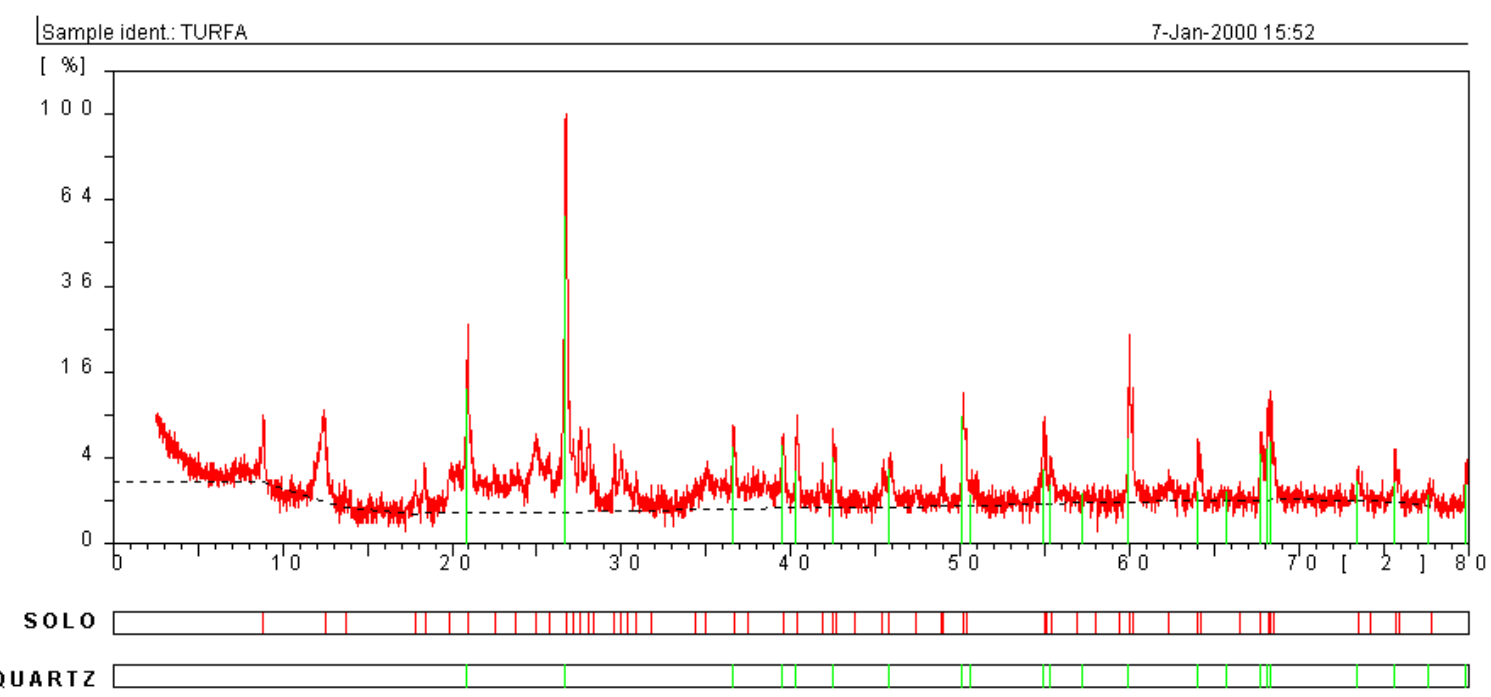

Fig. 12 - superposição do padrão difratométrico do quartzo ao difratograma 


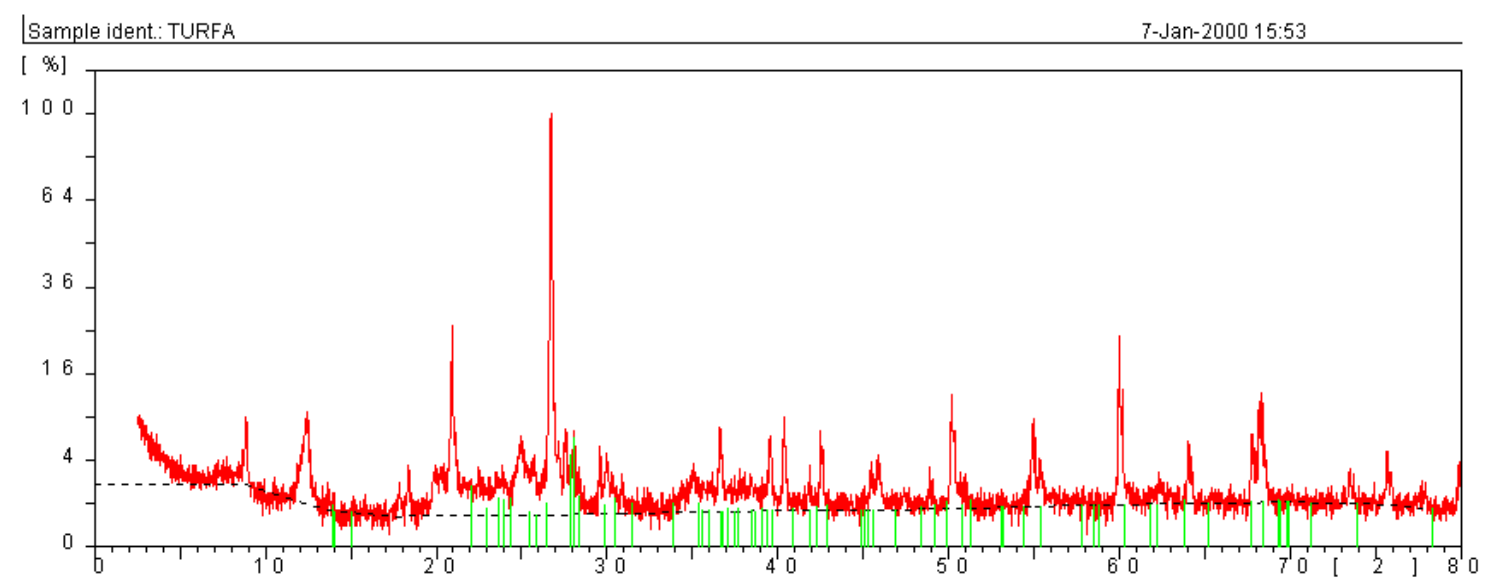

SOLO

ALBITE

Fig. 13 - superposição do padrão difratométrico da albita ao difratograma

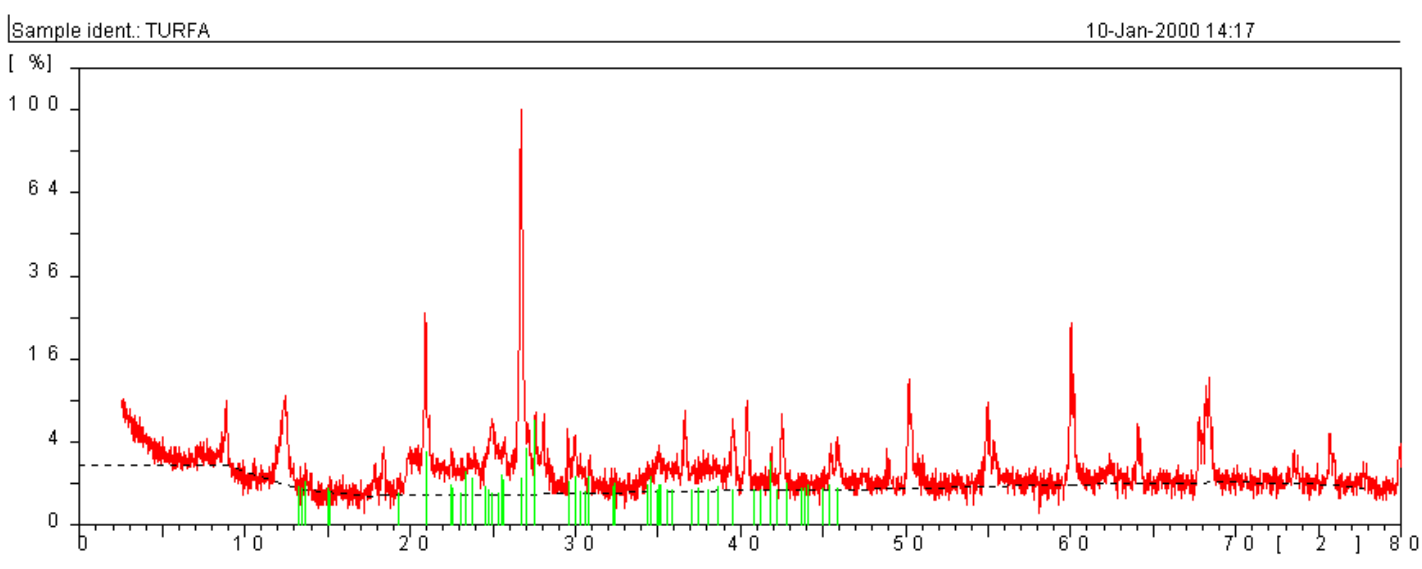

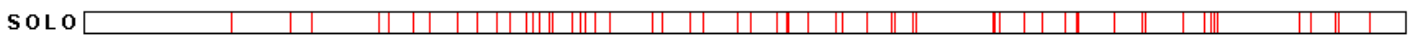
MICROCLINE

Fig. 14 - superposição do padrão difratométrico do microclíneo ao difratograma 


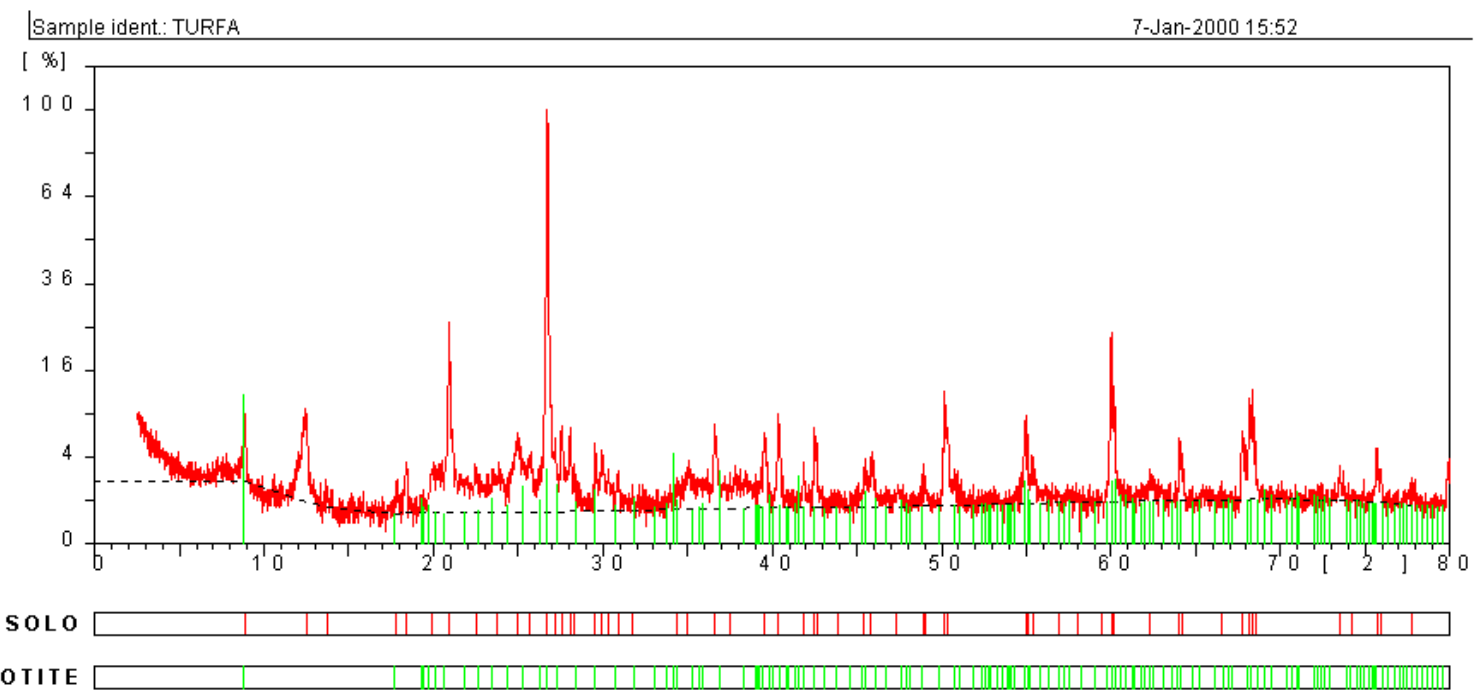

Fig. 15 - superposição do padrão difratométrico da biotita ao difratograma

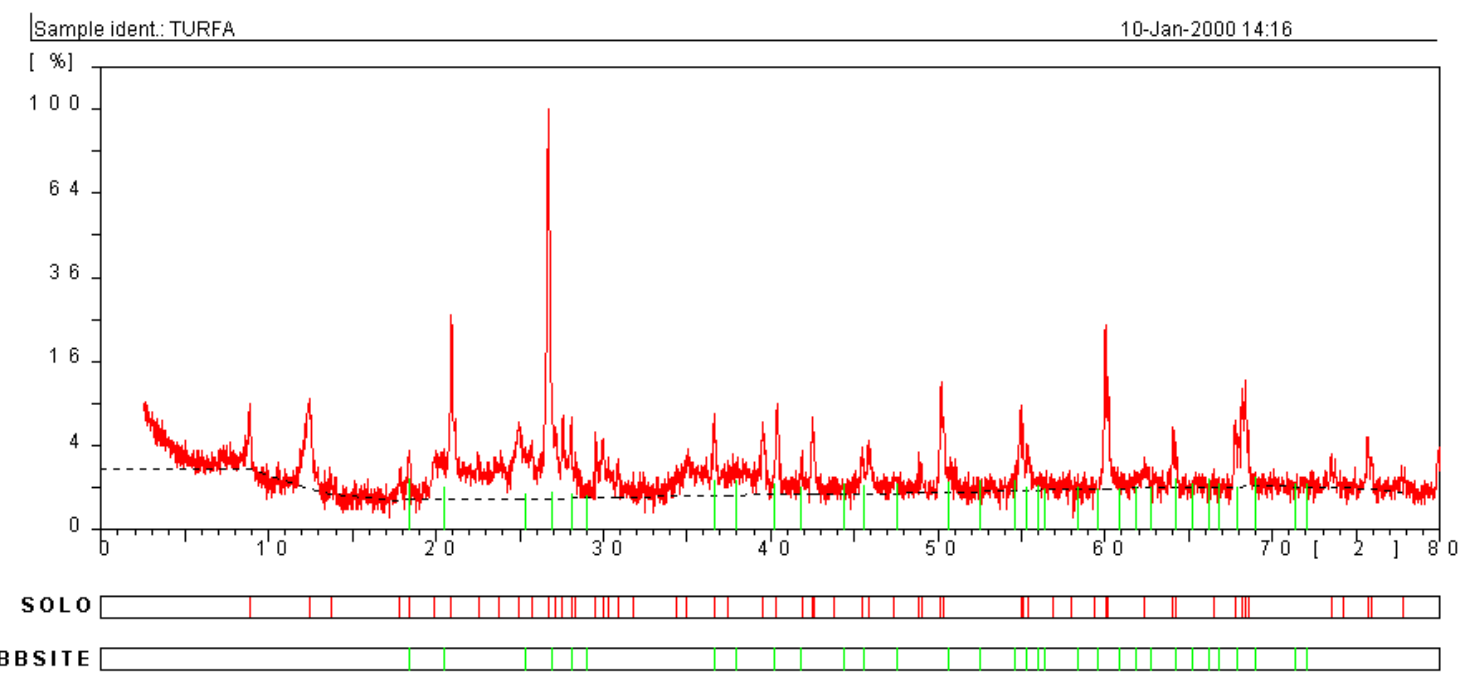

Fig. 16 - superposição do padrão difratométrico da gibsita ao difratograma 


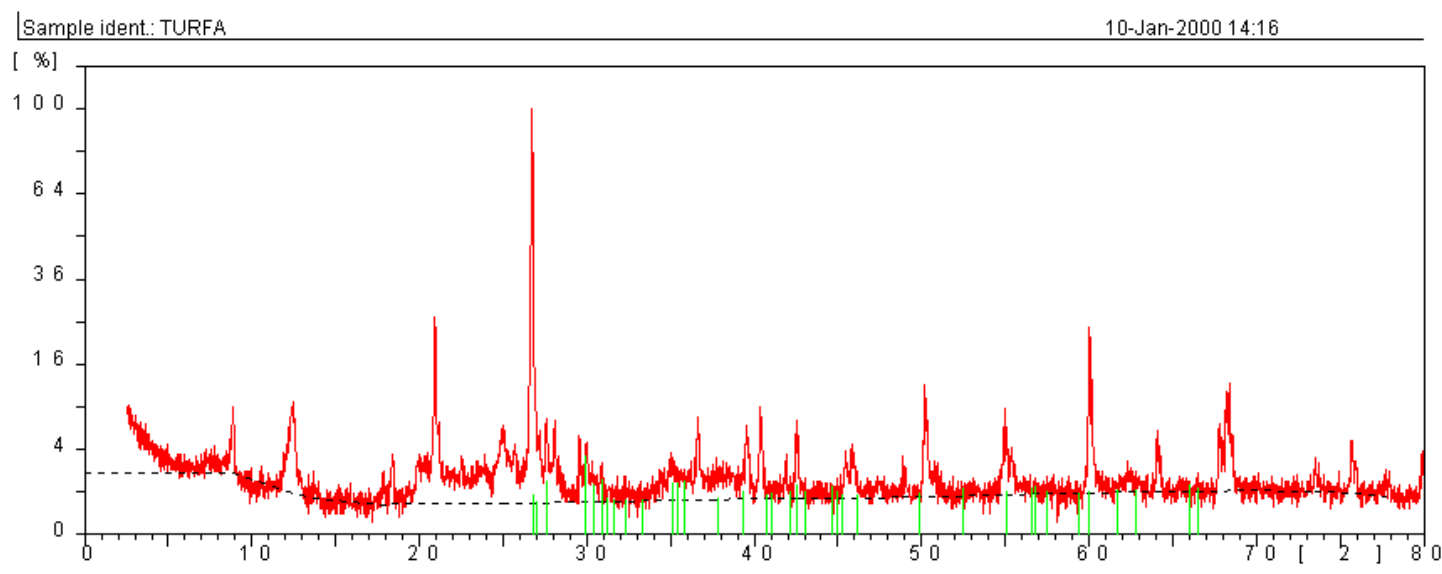

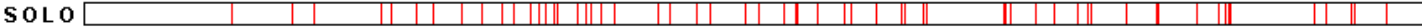
DIOPSIDE

Fig. 17 - superposição do padrão difratométrico do diopsídio ao difratograma
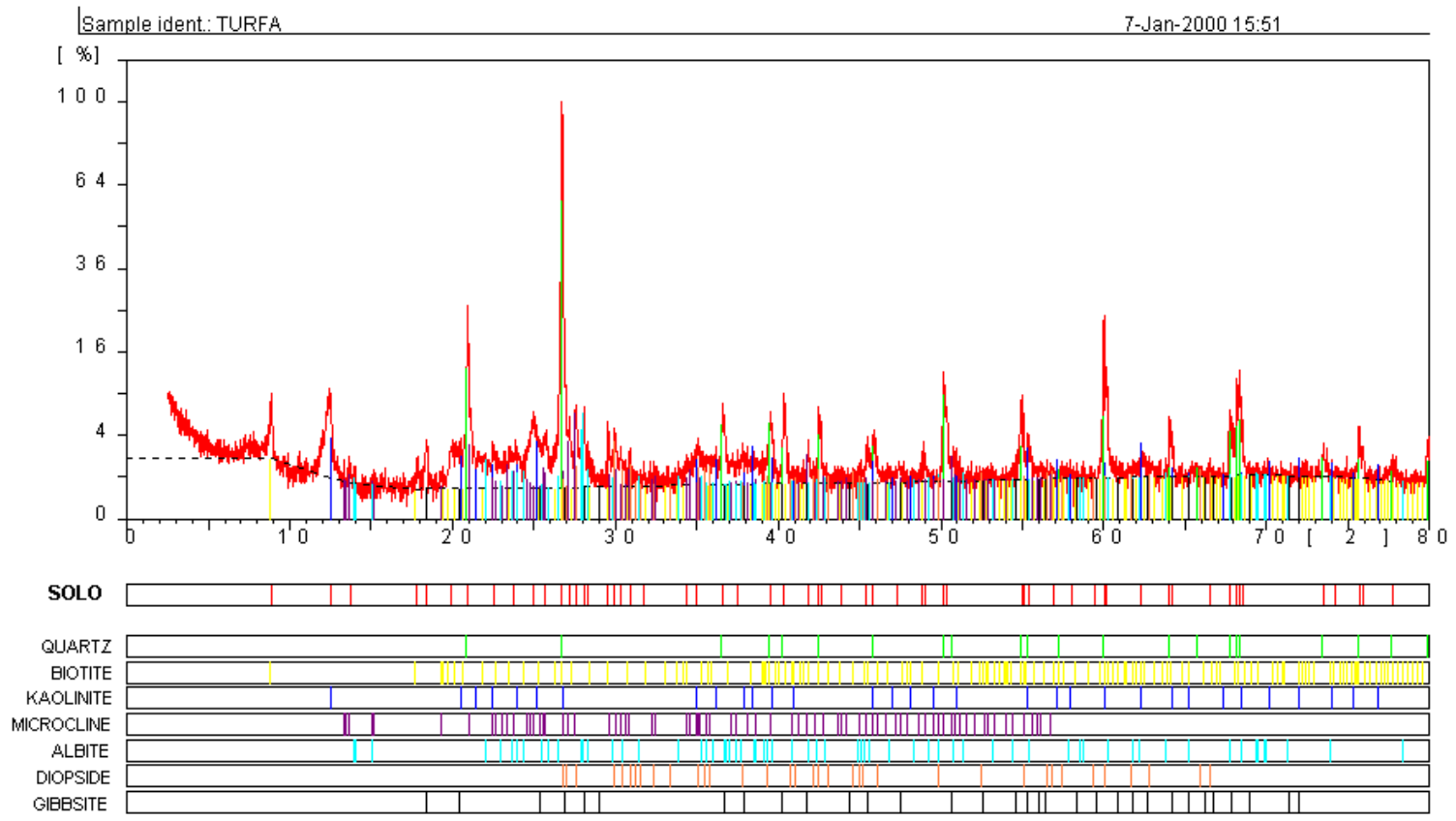

Fig. 18 - superposição dos padrões difratométricos de todos os minerais ao difratograma 


\subsubsection{Determinação do tamanho das partículas}

A análise revelou os seguintes parâmetros para o solo:

$d_{90}=328,53 \mu \mathrm{m}(90 \%$ do volume da amostra abaixo de $328,53 \mu \mathrm{m})$

$d_{50}=103,67 \mu \mathrm{m}(50 \%$ do volume da amostra abaixo de 103,67 $\mu \mathrm{m})$

$\mathrm{d}_{10}=14,43 \mu \mathrm{m}$ (10\% do volume da amostra abaixo de $\left.14,43 \mu \mathrm{m}\right)$

$D[4,3]=143,54 \mu \mathrm{m}$

$D[3,2]=22,59 \mu \mathrm{m}$

\subsubsection{Análise química}

A análise química semiquantitativa por fluorescência de raios- $X$ revelou os teores constantes da tabela 6 , em \% de óxidos:

Tab. 6 - análise química do solo por FRX

\begin{tabular}{llll}
\hline Componente & $(\%)$ & Componente & (\%) \\
\hline $\mathrm{SiO}_{2}$ & 63,9 & $\mathrm{BaO}$ & 0,06 \\
$\mathrm{Al}_{2} \mathrm{O}_{3}$ & 14,7 & $\mathrm{MnO}$ & 0,05 \\
$\mathrm{Fe}_{2} \mathrm{O}_{3}$ & 4,26 & $\mathrm{ZrO}_{2}$ & 0,04 \\
$\mathrm{~K}_{2} \mathrm{O}$ & 2,81 & $\mathrm{Rb}_{2} \mathrm{O}$ & 0,02 \\
$\mathrm{TiO}_{2}$ & 0,91 & $\mathrm{Cl}$ & 0,02 \\
$\mathrm{MgO}$ & 0,58 & $\mathrm{ZnO}$ & 0,01 \\
$\mathrm{CaO}$ & 0,33 & $\mathrm{SrO}$ & 0,01 \\
$\mathrm{Na}_{2} \mathrm{O}$ & 0,32 & $\mathrm{Ga}_{2} \mathrm{O}_{3}$ & 0,01 \\
$\mathrm{Cr}_{2} \mathrm{O}_{3}$ & 0,12 & $\mathrm{CuO}$ & $\mathrm{tr}$ \\
$\mathrm{SO}_{3}$ & 0,10 & & \\
\hline
\end{tabular}

A perda ao fogo (PF) representou $11,73 \%$.

\subsection{5 pH}

Foram obtidos os seguintes valores:

- $\mathrm{pH}$ em $\mathrm{KCl}=3,7$

- $\mathrm{pH}$ em $\mathrm{CaCl}_{2}=4,1$

- $\mathrm{pH}$ em $\mathrm{H}_{2} \mathrm{O}=5,3$ 


\subsubsection{Capacidade de Troca de Cátions, V (\%) e m (\%)}

Foram obtidas as determinações constantes da tabela 7, a seguir:

Tab. 7 - valores obtidos na determinação da CTC do solo

\begin{tabular}{cc}
\hline Componente & valor $\left(\mathbf{m m o l}_{\mathbf{c}} / \mathbf{k g}\right)$ \\
\hline $\mathrm{Na}^{+}$ & 0,70 \\
$\mathrm{~K}^{+}$ & 1,5 \\
$\mathrm{Ca}^{2+}$ & 12 \\
$\mathrm{Mg}^{2+}$ & 6 \\
$\mathrm{Al}^{3+}$ & 8 \\
$\mathrm{H}^{+}+\mathrm{Al}^{3+}$ & 51 \\
$\mathrm{~S}$ & 20,2 \\
$\mathrm{CTC}$ & 71,2 \\
\hline
\end{tabular}

Os parâmetros de fertilidade do solo apresentaram os seguintes valores:

$\mathrm{V}(\%)=28,37 \%$ (solo distrófico)

$\mathrm{m}(\%)=28,37 \%$ (solo não álico)

\subsubsection{Densidade das partículas}

Obteve-se o valor de $2,59 \mathrm{~g} / \mathrm{cm}^{3}$ (picnometria em água).

\subsubsection{Densidade Aparente}

Foram obtidos os valores constantes da tabela 8 , conforme o número de quedas adotado no procedimento de compactação.

Tab. 8 - valores de densidade aparente $\left(\rho_{b}\right)$ para o solo

\begin{tabular}{cc}
\hline Número de quedas & $\rho_{\mathrm{b}}\left(\mathbf{g} / \mathbf{c m}^{\mathbf{3}}\right)$ \\
\hline 50 & 1,21 \\
15 & 1,20 \\
5 & 1,13 \\
\hline
\end{tabular}




\subsubsection{Porosidade total}

Com a densidade aparente variando conforme o número de quedas adotado no procedimento de compactação, chegou-se aos valores para a porosidade total constantes da tabela 9 , lembrando que $S_{t}=1-\left(\rho_{b} / \rho_{p}\right) \times 100$ e $\rho_{p}=2,59 \mathrm{~g} / \mathrm{cm}^{3}$.

Tab. 9 - valores de porosidade total para o solo

\begin{tabular}{ccc}
\hline \multirow{2}{*}{ Número de quedas } & \multicolumn{2}{c}{ Porosidade total $(\%)$} \\
\cline { 2 - 3 } & $\begin{array}{c}\text { Por umidade a volume } \\
\left(\mathrm{cm}^{3} / \mathrm{cm}^{3}\right)\end{array}$ & $\begin{array}{c}\text { Por densidade } \\
\mathrm{t}=\left(1-\rho_{\mathrm{b}} / \rho_{\mathrm{p}}\right) \times 100\end{array}$ \\
\hline 50 & 56,46 & 53,28 \\
15 & 57,83 & 53,67 \\
5 & 64,26 & 56,37 \\
\hline
\end{tabular}

\subsection{CaracterizaÇÃo da tURFa}

\subsubsection{Grau de decomposição}

A turfa utilizada foi caracterizada como um material com elevado teor de fibras, pouco decomposto, com estrutura vegetal razoavelmente preservada; segundo a escala visual de von Post (quadro 1), pode ser situada entre os índices $\mathrm{H} 4$ e H5.

\subsubsection{Umidade}

Foram os seguintes os resultados obtidos para a umidade da turfa:

Base seca: $H_{s}=58,91 \%$

Base úmida: $\mathrm{H}_{\mathrm{u}}=37,07 \%$ 


\subsubsection{Análise química}

A análise química revelou os resultados constantes da tabela 10:

Tab. 10 - análise química da turfa

\begin{tabular}{ll}
\hline Elemento analisado & Valor \\
\hline matéria orgânica total (por combustão) & $93,4 \%$ (base seca) \\
Cinzas (100 - M.O.) & $6,6 \%$ \\
Carbono total (orgânico + mineral) & $51,90 \%$ \\
Carbono orgânico & $41,77 \%$ \\
$\mathrm{~N}$ (total) & $1,47 \%$ \\
$\mathrm{P}_{2} \mathrm{O}_{5}$ (total) & $0,15 \%$ \\
$\mathrm{~K}_{2} \mathrm{O}$ & $0,03 \%$ \\
$\mathrm{Ca}$ & $0,37 \%$ \\
$\mathrm{Mg}$ & $0,03 \%$ \\
$\mathrm{~S}$ & $0,15 \%$ \\
$\mathrm{C} / \mathrm{N}$ & $29 / 1$ \\
pH $(\mathrm{CaCl}$ & $2)$ \\
$\mathrm{CTC}$ & 3,0 \\
\hline
\end{tabular}

\subsubsection{Densidade aparente}

A densidade aparente (5 movimentos de queda) resultou em $0,27 \mathrm{~g} / \mathrm{cm}^{3}$.

\subsection{A ADIÇÃO DE TURFA AO SOLO}

Foram geradas quantidades entre 5 e $6 \mathrm{Kg}$ de cada uma das misturas solo+turfa, preparadas considerando-se a massa seca destes materiais, conforme pode ser observado na tabela 11. 
Tab. 11 - misturas solo+turfa (em peso)

\begin{tabular}{ccccc}
\hline \multirow{2}{*}{ Mistura } & \multicolumn{2}{c}{ Massa de solo (g) } & \multicolumn{2}{c}{ Massa de turfa (g) } \\
\cline { 2 - 5 } & (seco) & (tal qual) $\left.^{*}{ }^{*}\right)$ & (seca) & (tal qual) $^{\left({ }^{*}\right)}$ \\
\hline $2 \%$ & & & 100 & 158,9 \\
$4 \%$ & \multirow{2}{*}{5000} & 5393,2 & 200 & 317,8 \\
$6 \%$ & & & 300 & 476,7 \\
$8 \%$ & & & 400 & 635,6 \\
\hline
\end{tabular}

$\left(^{\star}\right)$ considerando-se a umidade natural dos materiais, ou seja,

$$
\mathrm{H}_{\mathrm{u}} \text { (solo) }=7,29 \%
$$

$\mathrm{H}_{\mathrm{u}}($ turfa $)=37,07 \%$

Considerando-se as densidades aparentes (turfa $=0,27 \mathrm{~g} / \mathrm{cm}^{3}$; solo $=$ $1,13 \mathrm{~g} / \mathrm{cm}^{3}$ ), pode-se, num exercício algébrico, definir as misturas preparadas em termos de volumes envolvidos $\left(\mathrm{V}_{\text {turfa }} / \mathrm{V}_{\text {solo }}\right)$, de acordo com a tabela 12. Estes números têm sua importância quando se tem em mente que, na prática de campo (preenchimento das covas que receberão as mudas), as misturas solo+adubos+esterco+calcário normalmente utilizadas são feitas em termos volumétricos.

Tab. 12 - misturas solo+turfa (em volume)

\begin{tabular}{cccccc}
\hline Mistura & \multicolumn{2}{c}{ TURFA } & \multicolumn{2}{c}{ SOLO } & $\begin{array}{c}\text { Mistura em } \\
\text { em peso }\end{array}$ \\
\cline { 2 - 6 } & Massa (g) & Volume $\left(\mathbf{c m}^{3}\right)$ & Massa (g) & Volume $\left(\mathbf{c m}^{3}\right)$ & $\mathbf{8 , 3 7 \%}$ \\
\hline $2 \%$ & 100 & 370,37 & & & $\mathbf{1 6 , 7 4 \%}$ \\
$4 \%$ & 200 & 740,74 & 5000 & 4424,78 & $\mathbf{2 5 , 1 1 \%}$ \\
$6 \%$ & 300 & 1111,11 & & & $\mathbf{3 3 , 4 8 \%}$ \\
$8 \%$ & 400 & 1481,48 & & & \\
\hline
\end{tabular}

\subsection{ENSAIOS FísICOS}

\subsubsection{Porosidade e densidade aparente}

As tabelas 13 a 16 apresentam os parâmetros físicos densidade aparente $\left(\rho_{b}\right)$, macro, meso e microporosidades obtidas através dos ensaios de retenção 
de água (funis de Haines e câmaras de Richards) para as condições de compactação anteriormente definidas (15 e 5 movimentos de queda).

A tensão do ensaio igual a $0 \mathrm{~cm} \mathrm{H}_{2} \mathrm{O}$ corresponde à amostra em seu ponto de saturação d’água; assume-se, aqui, que a massa de água nela contida corresponde ao seu volume total de poros.

Tab. 13 - valores obtidos nos ensaios de retenção de água à condição de compactação de 15 movimentos de queda

\begin{tabular}{|c|c|c|c|c|c|c|}
\hline Amostra & $\begin{array}{c}\text { Tensão do } \\
\text { ensaio } \\
\left(\mathrm{cmH}_{2} \mathrm{O}\right)\end{array}$ & $\begin{array}{c}\text { Massa } \\
\text { úmida }(\mathrm{g})\end{array}$ & $\begin{array}{c}\text { Massa } \\
\text { seca }(g)\end{array}$ & $\begin{array}{c}\text { massa de } \\
\text { água }(\mathrm{g})\end{array}$ & $\begin{array}{c}\rho_{b} \\
\left(\mathrm{~g} / \mathrm{cm}^{3}\right)\end{array}$ & $\begin{array}{c}\text { Umidade a } \\
\text { volume } \\
\left(\mathrm{cm}^{3} / \mathrm{cm}^{3}\right)\end{array}$ \\
\hline & 0 & 206,2 & 138,78 & 67,42 & & 0,58 \\
\hline \multirow[t]{3}{*}{ Branco } & 30 & 196,36 & 138,78 & 57,58 & 1,19 & 0,49 \\
\hline & 100 & 175,41 & 138,1 & 37,31 & & 0,32 \\
\hline & 0 & 203,02 & 132,18 & 70,84 & & 0,61 \\
\hline \multirow[t]{3}{*}{$2 \%$} & 30 & 192,51 & 132,18 & 60,33 & 1,13 & 0,52 \\
\hline & 100 & 168,98 & 131,8 & 37,18 & & 0,32 \\
\hline & 0 & 196,57 & 125,22 & 71,35 & & 0,61 \\
\hline \multirow[t]{3}{*}{$4 \%$} & 30 & 186,92 & 125,22 & 61,7 & 1,07 & 0,53 \\
\hline & 100 & 164,35 & 126,61 & 37,74 & & 0,32 \\
\hline & 0 & 192,33 & 118,89 & 73,44 & & 0,63 \\
\hline \multirow[t]{3}{*}{$6 \%$} & 30 & 181,75 & 118,89 & 62,86 & 1,02 & 0,54 \\
\hline & 100 & 157,84 & 120,00 & 37,84 & & 0,32 \\
\hline & 0 & 189,04 & 114,33 & 74,71 & & 0,64 \\
\hline \multirow[t]{2}{*}{$8 \%$} & 30 & 177,84 & 114,33 & 63,51 & 0,98 & 0,54 \\
\hline & 100 & 154,49 & 115,55 & 38,94 & & 0,33 \\
\hline
\end{tabular}

Tab. 14 - porosidades obtidas à condição de compactação de 15 movimentos de queda

\begin{tabular}{cccccc}
\hline Amostra & $\begin{array}{c}\text { Macroporo } \\
\text { sidade (\%) }\end{array}$ & $\begin{array}{l}\text { Mesoporo- } \\
\text { sidade (\%) }\end{array}$ & $\begin{array}{l}\text { Microporo- } \\
\text { sidade (\%) }\end{array}$ & $\begin{array}{l}\text { Porosidade } \\
\text { total (\%) }\end{array}$ & $\begin{array}{l}\text { Macro + } \\
\text { mesoporo- } \\
\text { sidade (\%) }\end{array}$ \\
\hline Branco & 8,44 & 17,39 & 32,00 & 57,83 & 25,83 \\
$\mathbf{2} \%$ & 9,02 & 19,86 & 31,89 & 60,77 & 28,87 \\
$\mathbf{4 \%}$ & 8,28 & 20,55 & 32,37 & 61,20 & 28,83 \\
$\mathbf{6 \%}$ & 9,08 & 21,46 & 32,46 & 63,00 & 30,54 \\
$\mathbf{8 \%}$ & 9,61 & 21,08 & 33,40 & 64,08 & 30,68 \\
\hline
\end{tabular}


Tab. 15 - valores obtidos nos ensaios de retenção de água à condição de compactação de 5 movimentos de queda

\begin{tabular}{|c|c|c|c|c|c|c|}
\hline Amostra & $\begin{array}{c}\text { Tensão do } \\
\text { ensaio } \\
\left(\mathrm{cmH}_{2} \mathrm{O}\right)\end{array}$ & $\begin{array}{c}\text { Massa } \\
\text { úmida }(\mathrm{g})\end{array}$ & $\begin{array}{c}\text { Massa } \\
\text { seca }(g)\end{array}$ & $\begin{array}{c}\text { massa de } \\
\text { água }(g)\end{array}$ & $\begin{array}{c}\rho_{b} \\
\left(g / \mathrm{cm}^{3}\right)\end{array}$ & $\begin{array}{c}\text { Umidade a } \\
\text { volume } \\
\left(\mathrm{cm}^{3} / \mathrm{cm}^{3}\right)\end{array}$ \\
\hline & 0 & 206,82 & 131,91 & 74,91 & & 0,64 \\
\hline \multirow[t]{3}{*}{ Branco } & 30 & 191,11 & 131,91 & 59,2 & 1,13 & 0,51 \\
\hline & 100 & 168,84 & 132,62 & 36,22 & & 0,31 \\
\hline & 0 & 204,6 & 129,14 & 75,46 & & 0,65 \\
\hline \multirow[t]{3}{*}{$2 \%$} & 30 & 184,63 & 129,14 & 55,49 & 1,11 & 0,48 \\
\hline & 100 & 165,03 & 129,54 & 35,49 & & 0,30 \\
\hline & 0 & 200,08 & 124,79 & 75,29 & & 0,65 \\
\hline \multirow[t]{3}{*}{$4 \%$} & 30 & 178,65 & 124,79 & 53,86 & 1,07 & 0,46 \\
\hline & 100 & 162,83 & 126,22 & 36,61 & & 0,31 \\
\hline & 0 & 198,69 & 122,4 & 76,29 & & 0,65 \\
\hline \multirow[t]{3}{*}{$6 \%$} & 30 & 175,7 & 122,4 & 53,3 & 1,05 & 0,46 \\
\hline & 100 & 158,36 & 121,31 & 37,05 & & 0,32 \\
\hline & 0 & 197,02 & 121,94 & 75,08 & & 0,64 \\
\hline \multirow[t]{2}{*}{$8 \%$} & 30 & 169,25 & 121,94 & 47,31 & 1,05 & 0,41 \\
\hline & 100 & 158,72 & 120,69 & 38,03 & & 0,33 \\
\hline
\end{tabular}

Tab. 16 - porosidades obtidas à condição de compactação de 5 movimentos de queda

\begin{tabular}{cccccc}
\hline Amostra & $\begin{array}{c}\text { Macroporo } \\
\text { sidade (\%) }\end{array}$ & $\begin{array}{l}\text { Mesoporo- } \\
\text { sidade (\%) }\end{array}$ & $\begin{array}{l}\text { Microporo- } \\
\text { sidade (\%) }\end{array}$ & $\begin{array}{l}\text { Porosidade } \\
\text { total (\%) }\end{array}$ & $\begin{array}{l}\text { Macro + } \\
\text { mesoporo- } \\
\text { sidade (\%) }\end{array}$ \\
\hline Branco & 13,48 & 19,71 & 31,07 & 64,26 & 33,19 \\
$\mathbf{2 \%}$ & 17,13 & 17,16 & 30,44 & 64,73 & 34,29 \\
$\mathbf{4 \%}$ & 18,38 & 14,80 & 31,40 & 64,58 & 33,18 \\
$\mathbf{6 \%}$ & 19,72 & 13,94 & 31,78 & 65,44 & 33,66 \\
$\mathbf{8 \%}$ & 23,82 & 7,96 & 32,62 & 64,40 & 31,78 \\
\hline
\end{tabular}

Estes dados podem ser melhor visualizados nos gráficos 1 e 2 que apresentam as porosidades em função da conformação a que foram submetidas as amostras. 


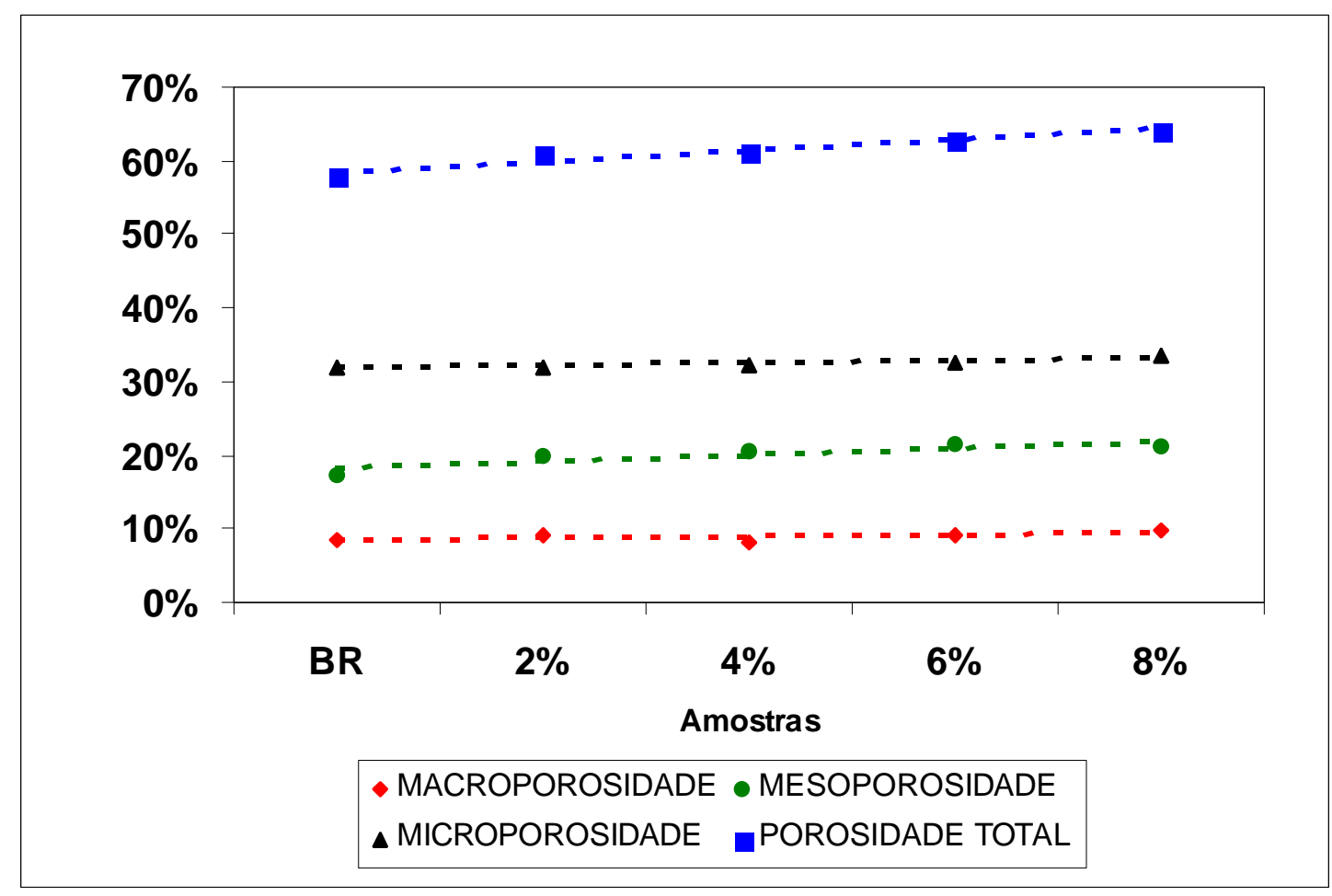

Gráfico 1 - porosidades à condição de 15 movimentos de queda

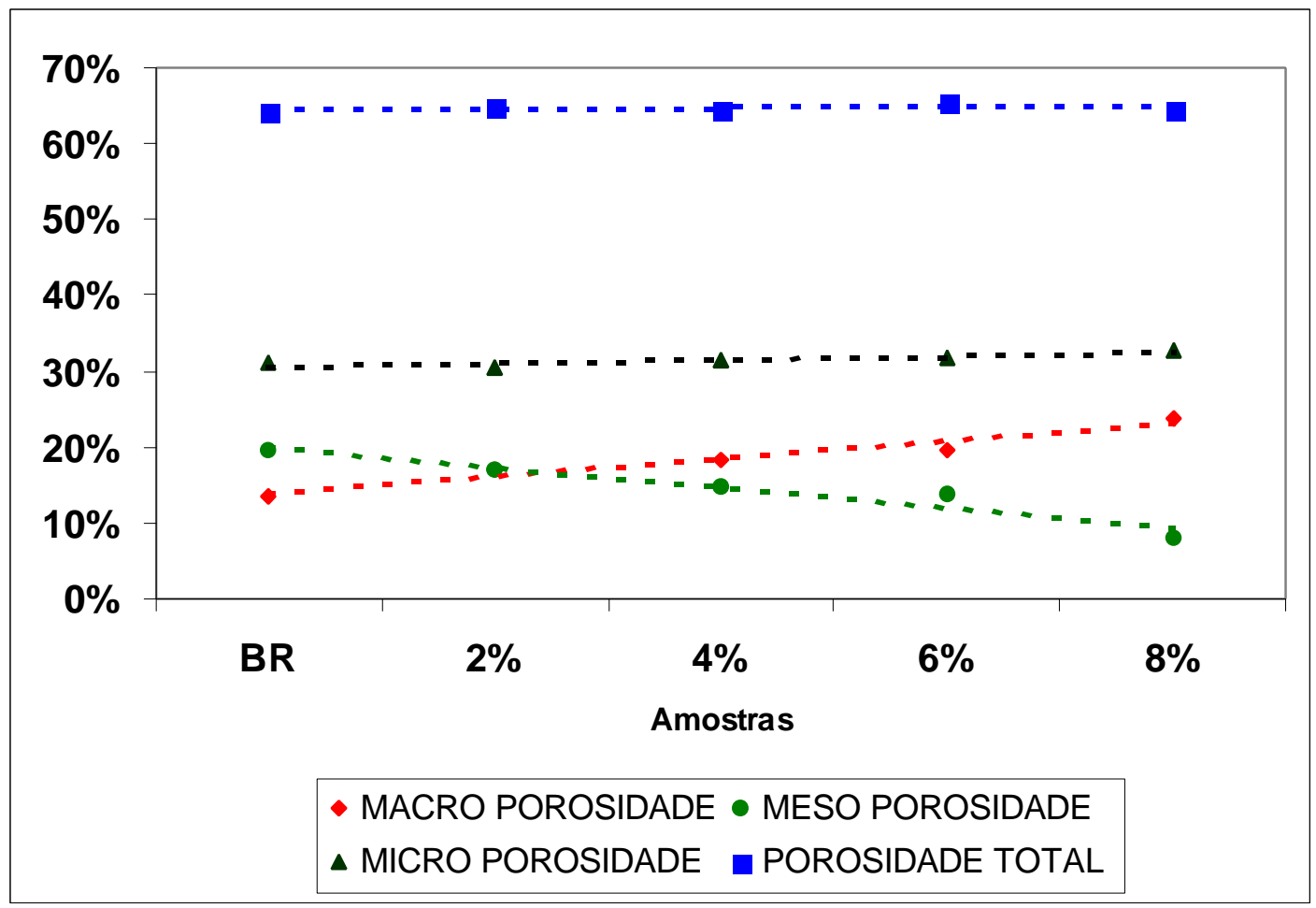

Gráfico 2 - porosidades à condição de 5 movimentos de queda 


\subsubsection{Condutividade hidráulica}

A tabela 17 contém os resultados dos ensaios de condutividade hidráulica realizados para as misturas conformadas à condição de 5 movimentos de queda, dados:

$A=38,32 \mathrm{~cm}^{2}=$ seção transversal do cilindro utilizado no ensaio

$\mathrm{L}=8 \mathrm{~cm}=$ comprimento da amostra

$\mathrm{T}=30$ minutos $=$ tempo de coleta d'água

Tab. 17 - valores obtidos nos ensaios de condutividade hidráulica

\begin{tabular}{ccccc}
\hline Amostra & $\begin{array}{c}\text { volume } \\
\left.\text { coletado(cm }{ }^{\mathbf{3}}\right)\end{array}$ & $\begin{array}{c}\text { altura da } \\
\text { coluna d'água } \\
(\mathbf{c m})\end{array}$ & $\begin{array}{c}\text { Carga } \\
\text { hidráulica }(\mathbf{c m})\end{array}$ & $\begin{array}{c}\text { Condutividade } \\
(\mathbf{c m} / \mathbf{h})\end{array}$ \\
\hline Branco & 176,67 & 7,3 & 15,3 & 4,82 \\
$\mathbf{2 \%}$ & 386,67 & 7,3 & 15,3 & 10,55 \\
$\mathbf{4 \%}$ & 493,33 & 7,0 & 15,0 & 13,73 \\
$\mathbf{6 \%}$ & 620,00 & 6,8 & 14,8 & 17,49 \\
$\mathbf{8 \%}$ & 496,67 & 6,5 & 14,5 & 14,30 \\
\hline
\end{tabular}

Estes resultados são graficamente expressos no Gráfico 3.

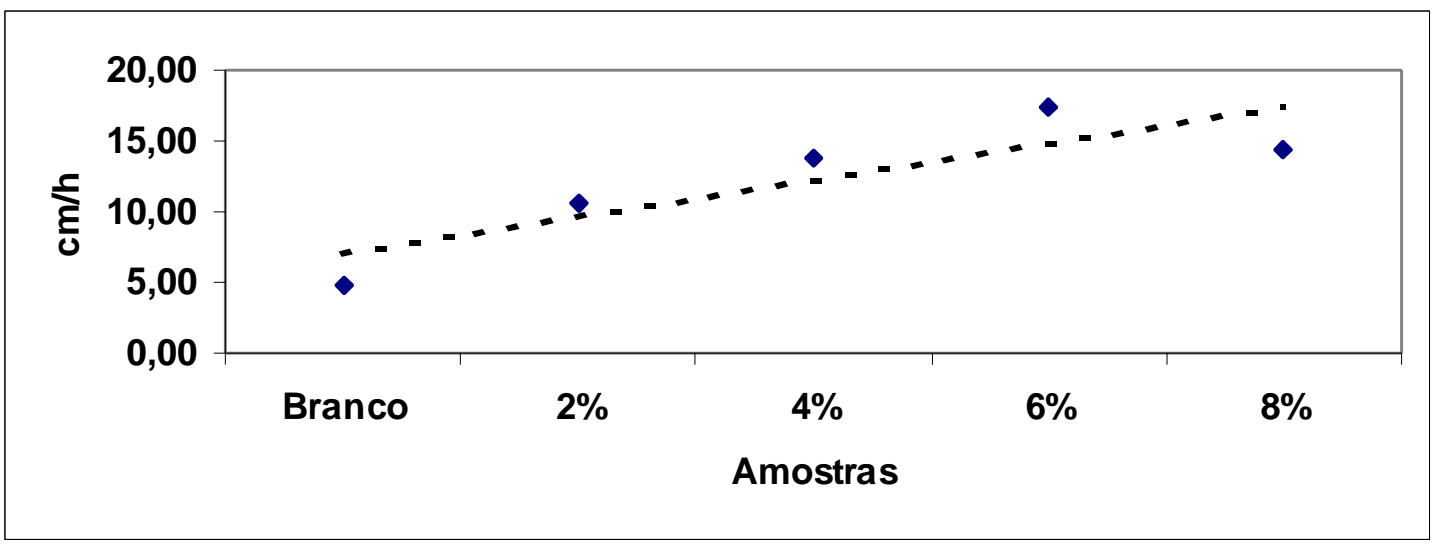

Gráfico 3 - condutividade hidráulica à condição de 5 movimentos de queda 


\subsection{ENSAIOS QUÍMICOS}

\subsubsection{Efeito tampão}

Apresentam-se na tabela 18 os dados envolvidos na adição do calcário dolomítico às diversas misturas, considerando-se sempre a massa seca dos materiais.

Tab. 18 - adição de calcário dolomítico às misturas

\begin{tabular}{ccccccccc}
\hline & Amostra & \multicolumn{6}{c}{ Calcário dolomítico adicionado (umidade = 0,16\%) } \\
\hline Ref. & $\begin{array}{c}\text { Umidade } \\
\text { (\%) }\end{array}$ & $\begin{array}{c}\text { massa } \\
\text { seca (g) }\end{array}$ & $\mathbf{0 , 5 \%}$ & $\mathbf{1 \%}$ & $\mathbf{1 , 5 \%}$ & $\mathbf{2 , 5 \%}$ & $\mathbf{5 \%}$ & $\mathbf{7 , 5 \%}$ \\
\hline Branco & 7,21 & 27,84 & 0,14 & 0,28 & 0,42 & 0,69 & 1,39 & 2,08 \\
$\mathbf{2 \%}$ & $\mathbf{8 , 6 8}$ & 27,40 & 0,14 & 0,27 & 0,41 & 0,68 & 1,37 & 2,05 \\
$\mathbf{4 \%}$ & 8,56 & 27,43 & 0,14 & 0,27 & 0,41 & 0,68 & 1,37 & 2,05 \\
$\mathbf{6 \%}$ & 10,23 & 26,93 & 0,13 & 0,27 & 0,40 & 0,67 & 1,34 & 2,02 \\
$\mathbf{8 \%}$ & 10,49 & $\mathbf{2 6 , 8 5}$ & 0,13 & 0,27 & 0,40 & 0,67 & 1,34 & 2,01 \\
\hline
\end{tabular}

Tab. 18 - cont.

\begin{tabular}{cccccccc}
\hline & Amostra & \multicolumn{5}{c}{ Calcário dolomítico adicionado (umidade = 0,16\%) } \\
\hline Ref. & $\begin{array}{c}\text { Umidade } \\
\text { (\%) }\end{array}$ & $\begin{array}{c}\text { massa } \\
\text { seca (g) }\end{array}$ & $\mathbf{1 0 \%}$ & $\mathbf{1 2 , 5 \%}$ & $\mathbf{1 5 \%}$ & $\mathbf{1 7 , 5 \%}$ & $\mathbf{2 0 \%}$ \\
\hline Branco & 7,21 & 27,84 & 2,78 & 3,47 & 4,17 & 4,86 & 5,56 \\
$\mathbf{2} \%$ & 8,68 & 27,40 & 2,74 & 3,42 & 4,10 & 4,79 & 5,47 \\
$\mathbf{4} \%$ & 8,56 & 27,43 & 2,74 & 3,42 & 4,11 & 4,79 & 5,48 \\
$\mathbf{6 \%}$ & 10,23 & 26,93 & 2,69 & 3,36 & 4,03 & 4,71 & 5,38 \\
$\mathbf{8 \%}$ & 10,49 & 26,85 & 2,68 & 3,35 & 4,02 & 4,69 & 5,36 \\
\hline
\end{tabular}

Os resultados das leituras de pH destas amostras figuram na tabela 19. 
Tab. 19 - pH's das misturas em função da adição de calcário dolomítico

\begin{tabular}{cccccc}
\hline Calcário \Mistura & $\mathbf{0 \%}$ & $\mathbf{2 \%}$ & $\mathbf{4 \%}$ & $\mathbf{6 \%}$ & $\mathbf{8 \%}$ \\
\hline $\mathbf{0 , 0} \%$ & 4,59 & 4,50 & 4,47 & 4,17 & 3,99 \\
$\mathbf{0 , 5} \%$ & 6,10 & 6,08 & 5,72 & 5,51 & 5,42 \\
$\mathbf{1 , 0} \%$ & 6,85 & 6,49 & 6,19 & 6,06 & 5,94 \\
$\mathbf{1 , 5 \%}$ & 7,09 & 6,75 & 6,47 & 6,28 & 6,20 \\
$\mathbf{2 , 5} \%$ & 7,20 & 7,07 & 7,01 & 6,74 & 6,78 \\
$\mathbf{5 , 0} \%$ & 7,42 & 7,30 & 7,54 & 7,08 & 7,20 \\
$\mathbf{7 , 5 \%}$ & 7,52 & 7,43 & 7,52 & 7,30 & 7,40 \\
$\mathbf{1 0 , 0} \%$ & 7,64 & 7,54 & 7,48 & 7,39 & 7,45 \\
$\mathbf{1 2 , 5 \%}$ & 7,70 & 7,57 & 7,48 & 7,55 & 7,49 \\
$\mathbf{1 5 , 0} \%$ & 7,70 & 7,64 & 7,62 & 7,55 & 7,51 \\
$\mathbf{1 7 , 5 \%}$ & 7,70 & 7,64 & 7,57 & 7,55 & 7,56 \\
$\mathbf{2 0 , 0} \%$ & 7,72 & 7,67 & 7,63 & 7,55 & 7,68 \\
\hline
\end{tabular}

O gráfico 4 apresenta as retas de tendência de $\mathrm{pH}$ para algumas das misturas (a representação de todos dificultaria a compreensão e visualização).

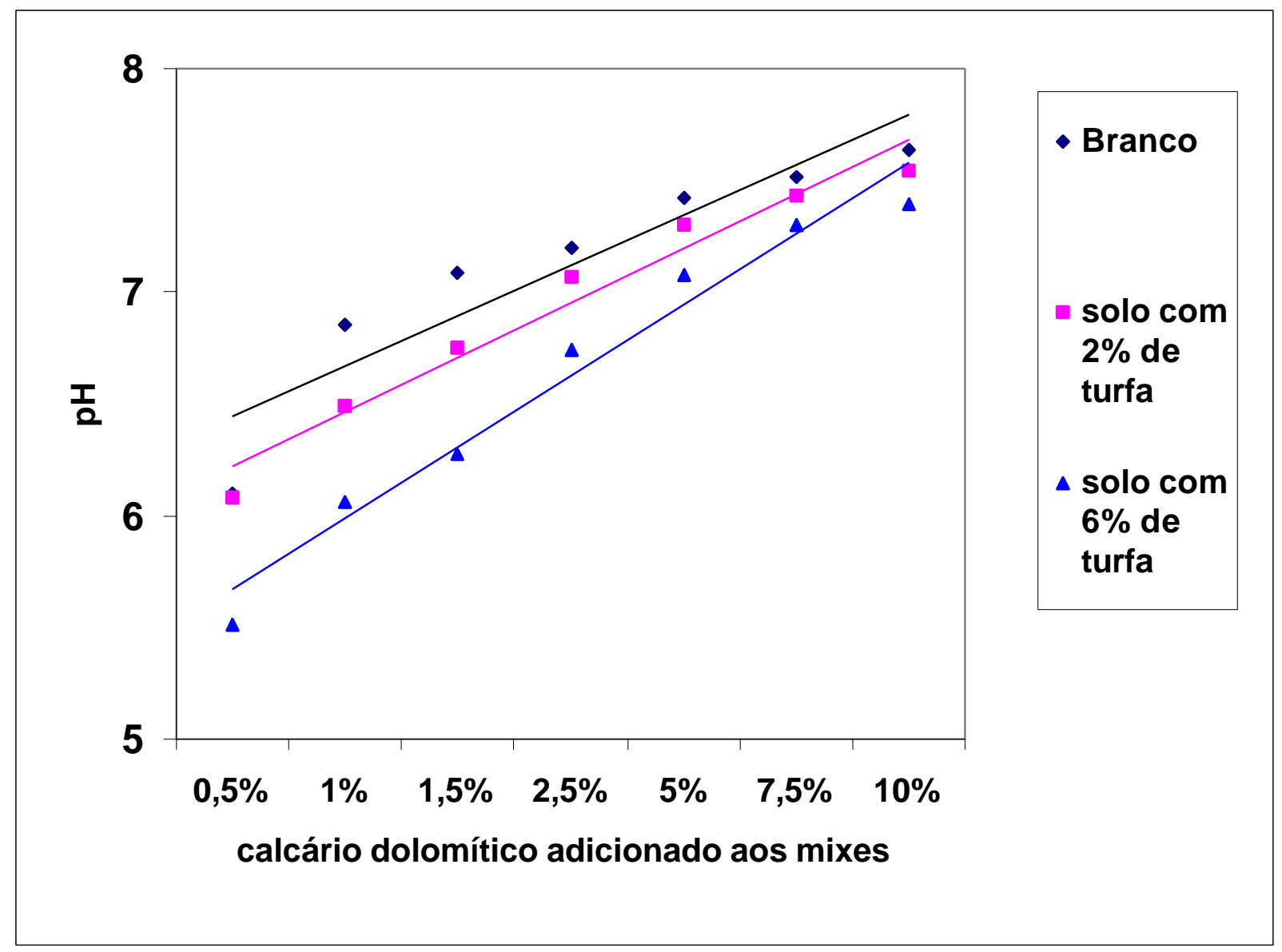

Gráfico 4 - pH das misturas em função da adição de calcário dolomítico 
A tabela 20 contém os valores de $\mathrm{pH}$ para as misturas às quais se adicionaram as soluções de $\mathrm{NaOH}$, graficamente expressos no Gráfico 5.

Tab. 20 - valores de pH das misturas em função da concentração de $\mathrm{NaOH}$

\begin{tabular}{ccccc}
\hline Amostra $\backslash[\mathrm{NaOH}]$ & $\mathbf{0}$ & $\mathbf{0 , 2 2} \mathbf{g} / \mathbf{l}$ & $\mathbf{1 , 0 2} \mathbf{g} / \mathbf{l}$ & $\mathbf{2 , 9 0 g} / \mathbf{l}$ \\
\hline Branco & 4,59 & 7,12 & 8,71 & 10,91 \\
$\mathbf{2} \%$ & 4,5 & 6,7 & 8,27 & 10,44 \\
$\mathbf{4} \%$ & 4,47 & 6,42 & 7,97 & 9,97 \\
$\mathbf{6} \%$ & 4,17 & 6,2 & 7,7 & 9,44 \\
$\mathbf{8} \%$ & 3,99 & 6,04 & 7,36 & 9,11 \\
\hline
\end{tabular}

\subsubsection{Capacidade de Troca de Cátions}

As análises de CTC das misturas, aditivadas com a solução policatiônica e posteriormente lavadas com água destilada, apresentaram os valores constantes da tabela 21.

Tab. 21 - CTC $\left(\mathrm{mmol}_{\mathrm{c}} / \mathrm{Kg}\right)$ das misturas solo+turfa+solução policatiônica, após lavagem

\begin{tabular}{cccccccccc}
\hline Amostra & $\mathbf{p H}\left(\mathbf{H}_{\mathbf{2}} \mathbf{O}\right)$ & $\mathbf{N a}$ & $\mathbf{K}$ & $\mathbf{C a}$ & $\mathbf{M g}$ & $\mathbf{A l}$ & $\mathbf{H}+\mathbf{A l}$ & $\mathbf{S B}$ & $\mathbf{C T C}$ \\
\hline & & & \multicolumn{7}{c}{$(\mathrm{mmolc} / \mathrm{Kg})$} \\
BR1 $\left.^{*}{ }^{*}\right)$ & 4,8 & 0,2 & 2,0 & 16 & 8 & 7 & 46 & 26,2 & 72,2 \\
Branco $^{2}$ & 3,9 & 0,2 & 11,2 & 13 & 9 & 11 & 59 & 33,4 & 92,4 \\
$\mathbf{2} \%$ & 3,8 & 0,3 & 12,0 & 12 & 8 & 13 & 80 & 32,3 & 112,3 \\
$\mathbf{4 \%}$ & 4,0 & 0,2 & 8,4 & 8 & 5 & 16 & 96 & 21,6 & 117,6 \\
$\mathbf{6 \%}$ & 3,8 & 0,2 & 7,9 & 8 & 6 & 17 & 102 & 22,1 & 124,1 \\
$\mathbf{8 \%}$ & 3,9 & 0,2 & 9,4 & 12 & 9 & 18 & 100 & 30,6 & 130,6 \\
\hline
\end{tabular}

${ }^{(*)}$ Amostra do solo sem adição da solução policatiônica, lavada nas mesmas condições que as demais. 


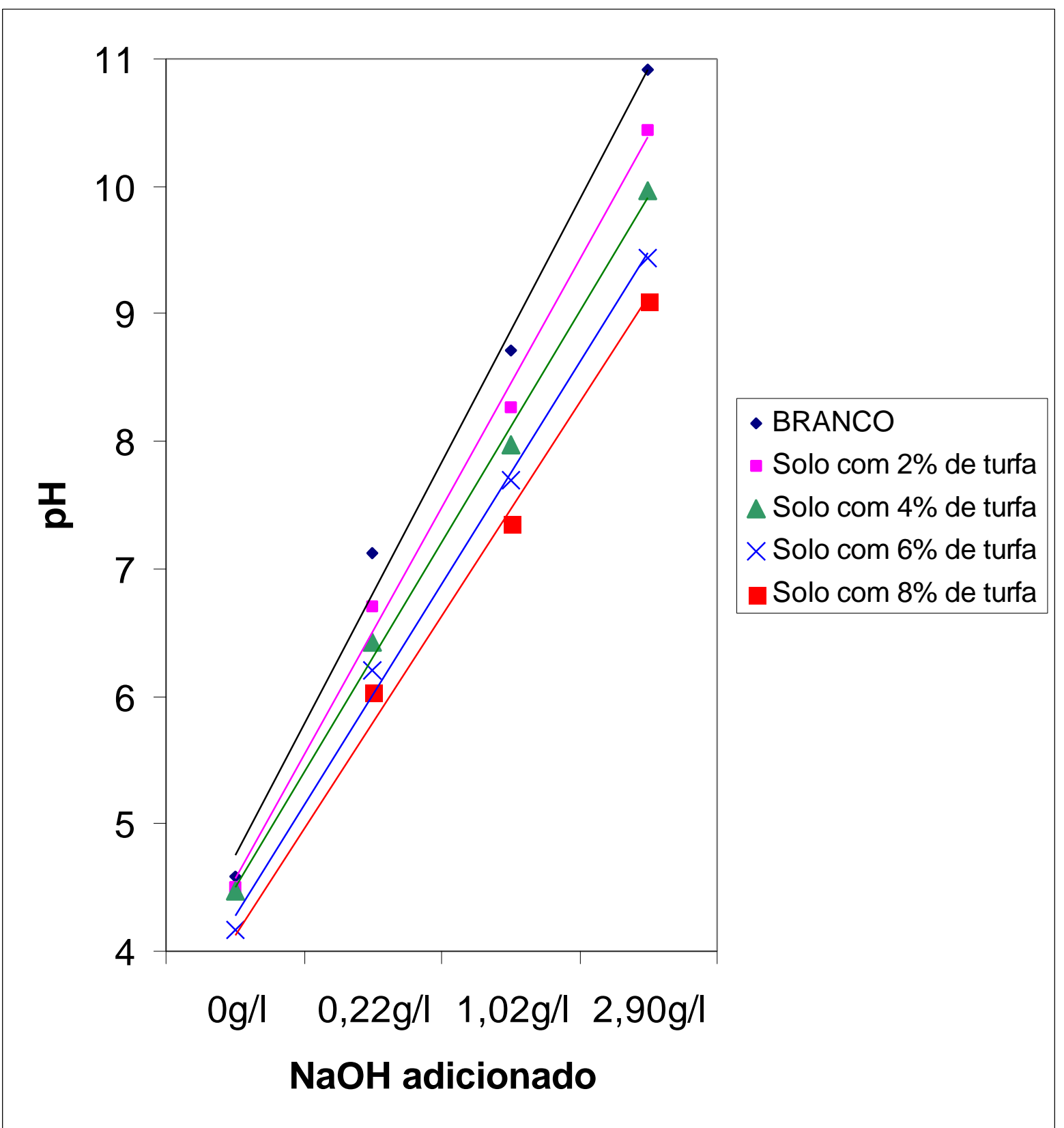

Gráfico 5 - pH das misturas em função da concentração de $\mathrm{NaOH}$ 
Análises químicas dos filtrados provenientes da lavagem das misturas encontram-se na tabela 22.

Tab. 22 - análises químicas dos filtrados provenientes da lavagem das misturas aditivadas com a solução policatiônica (valores em $\mathrm{mg} / \mathrm{Kg}$ )

\begin{tabular}{cccccccc}
\hline & Sol. estoque & Branco & $\mathbf{2 \%}$ & $\mathbf{4 \%}$ & $\mathbf{6 \%}$ & $\mathbf{8 \%}$ & BR1 $^{(*)}$ \\
\hline $\mathbf{P}$ & 4841 & 1754 & 1722 & 1700 & 1689 & 1777 & 16 \\
$\mathbf{K}$ & 38435 & 9327 & 8594 & 8386 & 8648 & 8368 & 9 \\
$\mathbf{Z n}$ & 90 & 28 & 25 & 25 & 26 & 25 & $<1$ \\
$\mathbf{F e}$ & 189 & 108 & 98 & 97 & 103 & 99 & $<1$ \\
$\mathbf{C u}$ & 12 & 3 & 3 & 3 & 3 & 2 & $<1$ \\
$\mathbf{M n}$ & 110 & 41 & 39 & 39 & 40 & 40 & $<1$ \\
$\mathbf{C a}$ & 13938 & 5437 & 5651 & 5748 & 5486 & 5655 & 5 \\
$\mathbf{M g}$ & 5043 & 2702 & 1425 & 2445 & 2796 & 2797 & $<1$ \\
\hline $\mathbf{p H}$ & 1,41 & 2,06 & 2,02 & 2,06 & 2,11 & 2,12 & 5,46 \\
\hline
\end{tabular}

(*) Amostra do solo sem adição da solução policatiônica, lavada nas mesmas condições que as demais. 


\section{DISCUSSÃO}

\subsection{MATERIAIS ENVOLVIDOS}

O solo em questão é representativo de ampla unidade pedológica do Vale do Paraíba, estendendo-se do município de Jacareí até as proximidades da cidade de Cruzeiro, ocorrendo nas várzeas dos rios principais e seus tributários.

A análise mineralógica (quartzo, feldspatos, mica e, possivelmente, piroxênio) é compatível com provável derivação das rochas constitutivas do embasamento pré-cambriano (gnaisses, migmatitos) circunvizinho.

Sua granulometria pode ser considerada como predominantemente fina mais de 50\% abaixo de 103,7 $\mu$ m (a peneira \# 150 Tyler tem abertura 105 $\mu \mathrm{m}$ ).

É um solo ácido como a maioria dos solos nacionais, com baixos valores dos principais parâmetros de fertilidade - matéria orgânica, V (\%), $m$ (\%) e CTC, bastante pertinentes, portanto, ao escopo do estudo proposto.

A turfa utilizada é o material atualmente comercializado para o mercado agrícola pela empresa que detém os direitos de lavra da jazida. Em função de seu elevado teor em matéria orgânica é, também, bastante adequada aos objetivos do presente estudo.

\subsection{ENSAIOS FísICOS}

Os parâmetros estudados nesta parte da proposta revelaram-se fortemente dependentes da condição considerada na conformação das amostras aos ensaios programados.

A densidade aparente $\rho_{\mathbf{b}}$, como observado nas tabelas 13 e 15, apresentou valores decrescentes com o acréscimo de turfa ao solo, como seria de se esperar com a adição sucessiva de um material de menor densidade aparente a outro que possua valor maior quanto a este parâmetro. 
A observação revela que a incorporação de um material altamente poroso e fibroso, como a turfa, traz ao solo a possibilidade de se evitar um dos maiores problemas na sua produtividade: a existência de adensamentos.

O método, entretanto, deixou transparecer algumas inconsistências, como as observadas para as misturas $4 \%$ (mesmos valores de $\rho_{b}$ para diferentes condições de compactação) bem como para 6\% e $8 \%$ (que, contrariamente às expectativas, apresentaram valores menores de $\rho_{b}$ nas condições mais severas de compactação).

Os valores de porosidade total para as diversas misturas, conforme salientado anteriormente, não variaram ou o fizeram de forma discreta, como no caso da condição de 15 movimentos de queda, o que valida a rota de estudos adotada de contemplar-se a determinação da distribuição de tamanho dos poros através de ensaios físico-hídricos.

A observação das tabelas 14 e 16, bem como dos gráficos 1 e 2 derivados, revela que os valores de microporosidade não apresentaram variações significativas para as duas condições de compactação adotadas; as variações esperadas fizeram-se presentes na macro e mesoporosidade das amostras.

$\mathrm{Na}$ condição de compactação de 15 movimentos de queda, tanto macro quanto mesoporosidade (e, consequentemente, a sua soma) apresentaram tendências crescentes com o aumento da quantidade de turfa utilizada. Tal soma mostrou-se acrescida em $11,8 \%$ para a mistura $2 \%$, relativamente ao Branco, e o ganho maior foi observado para a mistura $8 \%$ (aumento de 18,8\% em relação à amostra Branco).

$\mathrm{Na}$ condição de 5 movimentos de queda, a soma delas, embora de valores substancialmente maiores, pouco variou entre as amostras; houve, entretanto, variações evidentes de macro - em relação direta com o aumento da quantidade de turfa - e mesoporosidades - em relação inversa. A macroporosidade teve um incremento de $27,1 \%$ para a mistura $2 \%$, e encontrou melhor resultado na mistura $8 \%$, de $76,7 \%$ - valores todos referentes ao Branco. 
Houve possibilidade de se conduzirem os ensaios de condutividade hidráulica $[K(\theta)]$ apenas com as misturas na condição de compactação de 5 movimentos de queda.

Também aqui os resultados, conforme tabela 17 e gráfico 3, se revelaram pertinentes à proposição original, tendo-se observado uma relação direta desta propriedade dos solos com a quantidade de turfa adicionada às amostras, exceto quanto à mistura $8 \%$, que apresentou $\mathrm{K}(\theta)$ nos mesmos níveis da mistura 4\% (mas ainda substancialmente maior que a amostra Branco). Quantitativamente, houve um acréscimo de 118,9\% para a mistura $2 \%$, ficando o melhor resultado com a mistura $6 \%$, que foi $262,9 \%$ superior à amostra Branco.

Apesar das inconsistências elencadas, motivadas por possíveis inconformidades no preparo das misturas, no procedimento de compactação, na homogeneização das amostras, erro analítico ou fatores que fogem ao controle da presente investigação (clima, tempo necessário à ocorrência de alterações, ação da micro e mesovida edáficas na estruturação dos solos), os resultados dos ensaios físico-hídricos corroboram as premissas aventadas de consignar ao solo um espaço poroso redesenhado pela incorporação de turfa, no sentido do aumento nos valores de macro e mesoporosidades bem como da condutividade hidráulica, fatores altamente desejáveis à sua maior produtividade.

\subsection{ENSAIOS QUÍMICOS}

\section{Efeito tampão}

O efeito tampão esperado pela adição de turfa ao solo - ou seja, as variações sucessivamente menores dos valores de $\mathrm{pH}$ em solos com teores crescentes de matéria orgânica em resposta a procedimentos habituais de calagem e adubação - foi estudado em experimentos com adição de calcário dolomítico e de hidróxido de sódio. 
O calcário dolomítico elevou $\mathrm{o} \mathrm{pH}$ de todas as misturas até aproximadamente a proporção de adição de $12,5 \%$ em peso, como evidenciado pelos dados constantes na tabela 19; seu acréscimo além destes teores pouco influiu no $\mathrm{pH}$ do solo, provavelmente em razão da saturação ou baixa solubilidade desta substância. Grosso modo, pode-se afirmar que a aplicação de $1 \%$ em peso de calcário dolomítico ao solo corresponde, em campo, à aplicação de 30t/ha, considerando-se que tha de solo arado tem, aproximadamente, 3000 toneladas de peso.

A amplitude da faixa em que o $\mathrm{pH}$ variou para as diferentes misturas, tendo em vista a adição de igual quantidade de calcário, foi, entretanto, aproximadamente a mesma para todos, fato que frustrou as expectativas originalmente nutridas de que estas variações pudessem ser sucessivamente menores com o aumento da quantidade de matéria orgânica no solo.

Por outro lado, a adição de hidróxido de sódio comprovou o efeito de tamponamento conferido pela turfa quando utilizada como um insumo extra nos procedimentos habituais de tratamento e correção de solos.

Analogamente à aplicação de calcário dolomítico, o NaOH também elevou $0 \mathrm{pH}$ das misturas em todas as proporções utilizadas; também de maneira aproximada, pode-se afirmar que a aplicação de $25 \mathrm{ml}$ de solução de $1,0 \mathrm{~g} / \mathrm{l}$ de $\mathrm{NaOH}$ a $10 \mathrm{~g}$ de solo corresponde a aplicação de 7,5 t/ha de $\mathrm{NaOH}$.

A tabela 20 e o gráfico 5 revelam que para o solo "in natura" a adição de $\mathrm{NaOH}$ fez o pH variar entre 4,59 e 10,91 (amplitude de 6,32); para o mix 8\%, a variação situou-se entre 3,99 e 9,11 (amplitude de 5,12); quantidades intermediárias de turfa adicionada aos solos apresentaram amplitudes intermediárias entre os valores acima apontados (respectivamente, 5,94, 5,5 e $5,27)$.

\section{Capacidade de Troca de Cátions}

A possibilidade de aumento da CTC do solo pela adição de turfa foi avaliada através de dois expedientes:

- a determinação da CTC das misturas aditivadas com a solução policatiônica após o procedimento de lavagem; 
- análise química dos filtrados desta lavagem.

A amostra BR1 representa um "branco" não aditivado com a solução policatiônica, mas submetido às demais condições do ensaio (lavagem e filtração).

Da análise da tabela 21, que contém as CTC's das amostras lavadas, nota-se, pelos resultados das amostras Branco e BR1, que a simples adição da solução policatiônica provoca aumento na CTC total do solo, da ordem de $28 \%$, o que pode ser explicado pelo teor em matéria orgânica nele existente, determinado como sendo de $11,73 \%$ (não se pode creditar este aumento à presença da caulinita, único argilomineral identificado neste solo nas análises por DRX e, reconhecidamente, de baixo poder de retenção de cátions trocáveis).

Nota-se também que este aumento ocorre para todos os cátions trocáveis, exceto $\mathrm{Na}$ e $\mathrm{Ca}$. Ressalte-se que o sódio não foi analisado por não estar presente na solução adicionada. O cálcio constitui, inclusive, o cátion trocável preponderante $\left(\mathrm{H}^{+}\right.$à parte) no solo "in natura" e, em que pese estar presente em quantidade significativa na solução policatiônica $(13938 \mathrm{mg} / \mathrm{Kg})$, não ocorreu aumento correspondente na CTC para este cátion tomado individualmente. A não retenção do $\mathrm{Ca}^{2+}$ em sua forma trocável pode indicar forte interferência dos demais constituintes da solução adicionada. A presença de turfa nas misturas acentuou mais esta observação, uma vez que a quantidade trocável deste cátion apresentou-se ainda mais deprimida, indicando que a utilização desta turfa potencializou a não retenção de $\mathrm{Ca}^{2+}$ trocável no solo, contrariamente ao observado por PETRONI (1999). Este autor observou, em experimentos envolvendo a adsorção de Zn e Cd por uma turfa proveniente do Estado de Santa Catarina, a partir de soluções sintéticas, que a adsorção daqueles metais foi bastante prejudicada quando $\mathrm{Ca}^{2+}$ foi adicionado à solução, constituindo-se em elemento fortemente interferente no fenômeno e de alta afinidade à referida turfa.

O mesmo pode ser afirmado relativamente aos teores de $\mathrm{K}$ e $\mathrm{Mg}$, cujos teores se apresentaram, via de regra, inferiores à amostra Branco, ou seja, a presença de turfa pouco ou nada influiu na retenção destes cátions em sua forma trocável. 
O parâmetro SB ilustrou bem estas constatações, uma vez que o maior valor foi observado exatamente para a amostra Branco.

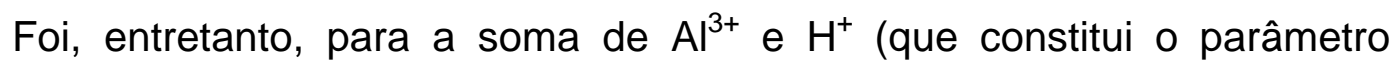
"acidez trocável" do solo e componente da CTC total) que os valores se tornaram gradativamente maiores, à medida que aumentou a proporção de turfa nas misturas (aumento de CTC de 35,6\% para a mistura $2 \%$ ) e, a exemplo do ocorrido com os demais cátions trocáveis, também sofreu incremento (de cerca de $28 \%$ ) com a simples adição da solução policatiônica às amostras. $O$ aumento pronunciado deste parâmetro refletiu-se na CTC total, que apresentou relação direta com a quantidade de turfa adicionada às amostras: 0 aumento de $21,5 \%$ obtido para a mistura $2 \%$ ascendeu a $41,3 \%$ para a mistura $8 \%$, que se constituiu no melhor resultado dentre as amostras estudadas.

Por outro lado, à luz dos dados constantes na tabela 22, pode-se inferir, em que pese a pequena variação entre os dados analíticos obtidos, que a turfa adicionada ao solo lhe conferiu um aumento no poder de retenção de quase todos os elementos analisados (à exceção do $\mathrm{Ca}$ ):

- a amostra Branco apresenta teores sempre maiores, relativamente às misturas, em K, Zn, Fe e Mn, indicando ter havido retenção destes cátions nas amostras contendo turfa;

- comportamento semelhante é observado para o $\mathrm{P}$, exceto quanto à mistura $8 \%$ que, paradoxalmente, apresentou níveis de retenção inferiores à amostra Branco;

- a retenção de Cu somente foi observada para a mistura contendo o maior teor em turfa (8\%), embora, em função da pequena magnitude dos teores envolvidos, pouco se possa afirmar relativamente à retenção para este elemento;

- ocorre retenção de $\mathrm{Mg}$ nas misturas 2\% e 4\%, comportamento invertido, entretanto, para aquelas com maior quantidade de turfa;

- nenhuma das amostras contendo turfa conseguiu retenção de Ca além do nível propiciado pela amostra Branco; este comportamento anômalo é também corroborado na análise de CTC: como se pode observar na tabela 21 , relativamente às demais amostras, o Ca é o único elemento presente em maior teor na amostra BR1, denotando que a solução policatiônica 
desloca ou, de alguma forma, não permite a fixação do Ca trocável nas amostras, contenham elas turfa ou não.

Deve-se ressaltar não ter sido possível o controle de $\mathrm{pH}$ durante a experimentação, fato de considerável relevância tendo em vista $0 \mathrm{pH}$ medido para a solução policatiônica: 1,41 (tabela 22). PETRONI (1999), afirma ser a adsorção de metais pela turfa fenômeno altamente dependente do $\mathrm{pH}$, bastante prejudicado abaixo do valor 3,5 e praticamente nulo quando inferior a 2,0 .

Em que pese a observação acima, a análise dos dados obtidos permite concluir que a turfa, mesmo de forma discreta, efetivamente confere um aumento na retenção na maioria dos nutrientes - se não em todos contidos nos fertilizantes, o que ficou patente nos experimentos para todos os elementos rastreados, uns com mais outros com menos aumento, com exceção do Ca.

Esta constatação tem sua importância por significar a possibilidade de se atenuarem os efeitos da lixiviação, um dos fatores mais prejudiciais à produtividade dos solos, e pesado ônus à agricultura de países de clima tropical.

Os resultados obtidos poderão ser mais consentâneos àqueles presumidos, se outras condições de ensaio forem tentadas, contemplando-se:

- o tamponamento da solução policatiônica utilizada a um pH maior;

- um tempo maior de contato entre as misturas e a solução policatiônica, na expectativa de se propiciar uma adsorção mais efetiva; ou

- uma lixiviação por lavagem mais intensa das misturas, procurando estabelecer contraste maior para os resultados obtidos entre as misturas com turfa, de um lado, e o Branco, de outro.

\subsection{SUGESTÕES PARA TRABALHOS FUTUROS}

A comprovação prática dos resultados aqui obtidos deve ser buscada com experimentação de campo, o que pode ser conseguido em área semelhante à 
enfocada neste trabalho. Sugere-se a aplicação periódica de turfa num módulo eleito da área, que possa ser comparado a outros que não recebam o tratamento com turfa (branco), e o competente monitoramento através de amostragens do solo, também periódicas, por técnicas que propiciem a coleta de amostras, devidamente conformadas, para submissão aos ensaios físicohídricos e químicos aqui realizados.

A área do módulo poderia ser de 1ha, a periodicidade de incorporação de turfa de 1 ano e as amostragens periódicas também de 1 ano (realizadas entre os períodos de aplicação da turfa).

A proporção de aplicação poderia ser a mínima aqui utilizada - $2 \%$ - o que equivaleria a 60t/ha de turfa com umidade zero (condições das misturas aqui preparadas) ou a aproximadamente 95t/ha de turfa com a umidade determinada neste trabalho $\left(\mathrm{H}_{\mathrm{u}}=37,07 \%\right)$.

Nestas condições, fatores como regime climático e, principalmente, tempo, constituiriam ingredientes significativos não possíveis de consideração na presente experimentação. Alterações físicas, químicas e biológicas do solo seriam então estudadas num contexto real para convalidar as conclusões deste trabalho.

Sugere-se contemplar, também, a utilização de um litotipo de turfa mais decomposto, o sáprico, ou seja, aquele classificado acima do grau 7 na escala de von Post (Quadro 1) nos experimentos. Frente aos litotipos mais fibrosos, esta variedade apresenta, normalmente, maior teor de ácidos húmicos, superfície específica e capacidade adsortiva, em detrimento do eventual prejuízo das características hidráulicas (tabela 2). 


\section{CONCLUSÕES}

O presente trabalho logrou comprovar, no âmbito laboratorial, a eficácia da utilização da turfa como melhorador de solos degradados ou que apresentem deprimidos seus principais parâmetros de fertilidade.

Em resposta às hipóteses de trabalho inicialmente formuladas, a adição de turfa ao solo conseguiu alterar favoravelmente algumas de suas propriedades físicas - diminuição da densidade aparente, aumento da quantidade de macro e/ou mesoporos e da condutividade hidráulica - fatores de elevada importância à circulação de fluidos e ao desenvolvimento de raízes pivotantes, capazes de explorar maior volume de solo em busca de água e nutrientes.

Obtiveram-se, também, melhorias das propriedades químicas CTC e efeito tampão, o que permite aos solos maior capacidade de reter os nutrientes da adubação contra a lixiviação promovida pelas chuvas intensas características do clima tropical, e proteção à sua micro e mesofauna contra as bruscas modificações de $\mathrm{pH}$ do meio.

Embora não constitua objetivo precípuo do presente trabalho qualquer dimensionamento ou desenvolvimento de produtos, pode-se afirmar — tendo em vista as condições experimentais, os resultados obtidos e, principalmente, as ressalvas quanto a condições não passíveis de controle durante a experimentação - que $2 \%$ de adição de turfa ao solo seriam suficientes para promover a melhoria das propriedades do solo estudadas neste trabalho, nos níveis aqui observados.

Os resultados credenciam-na, assim, à utilização em programas de recuperação ambiental de áreas degradadas, seja pela mineração, seja em decorrência de quaisquer outros empreendimentos modificadores do meio físico.

Numa visão transcendente à atuação como profissionais da mineração, a turfa poderá encontrar amplo campo de aplicação em cultivos agrícolas tradicionais. No Brasil, o histórico da ocupação agrícola conduziu irresponsavelmente à exaustão suas terras mais férteis sob a enganosa 
percepção de que, função da vasta extensão territorial, elas sempre se constituiriam recursos inesgotáveis.

A produção agrícola deve ser prioridade de todas as nações para se erradicar o maior flagelo da humanidade em tempos contemporâneos: a fome. Enquanto pouco se produzir por área unitária, serão sempre e igualmente elevados o custo e o preço dos produtos.

Retenção de nutrientes, redução do uso de fertilizantes, agrotóxicos e irrigação, conservação dos solos e aumento geral na produtividade constituem alguns dos ingredientes a serem perseguidos para atingir esta meta. 


\section{REFERÊNCIAS BIBLIOGRÁFICAS}

ALMEIDA, A. C. et al. Aplicação de técnicas alternativas na recuperação de área degradada, estudo de caso na Aracruz Celulose. In: SIMPÓSIO SULAMERICANO, 1./ SIMPÓSIO NACIONAL RECUPERAÇÃO DE ÁREAS DEGRADADAS, 2., Foz de Iguaçu, 1994. Anais. Curitiba, Fundação de Pesquisas Florestais do Paraná, 1994. p. 473-86.

ANDREJKO, M. J.; FIENE, F.; COHEN, A. D. Comparison of ashing techniques for determination of the inorganic content of peats. In: SYMPOSIUM ON TESTING OF PEATS AND ORGANIC SOILS, Toronto, 1982. Proceedings. Toronto, ASTM., 1983. p. 5-20.

BITAR, O. Y. Avaliação da recuperação de áreas degradadas por mineração na Região Metropolitana de São Paulo. São Paulo, 1997. 184 p. Tese (Doutorado) - Escola Politécnica, Universidade de São Paulo.

BLAKE, G. R. ; HARTGE, K. H. Particle density. In: KLUTE, A., ed. Methods of soil analysis. Madison, American Society of Agronomy and Soil Science Society of America, 1987. v. 1, p. 377-82. (Agronomy, 9)

BONI, N. R.; ESPÍNDOLA, C. R.; GUIMARÃES, E. C. O uso de leguminosas na recuperação de um solo decapitado. In: SIMPÓSIO SUL-AMERICANO, 1./ SIMPÓSIO NACIONAL RECUPERAÇÃO DE ÁREAS DEGRADADAS, 2., Foz de Iguaçu, 1994. Anais. Curitiba, Fundação de Pesquisas Florestais do Paraná, 1994. p. 563-8.

BONNEAU, M. ; LEVY, G. Assembly and physical organization of particles. In: BONNEAU, M. ; SOUCHIER, B., coords. Constituents and properties of soils. New York, Academic Press, 1982. p. 268-87.

BRASIL. Ministério da Agricultura. Serviço Nacional de Levantamento e Conservação de Solos. Manual de métodos de análise de solo. 2.ed. Rio de Janeiro, EMBRAPA-CNPS, 1997.

BRASIL. Ministério do Interior. Instituto Brasileiro do Meio Ambiente e dos Recursos Naturais Renováveis. Manual de recuperação de áreas degradadas pela mineração: técnicas de revegetação. Brasília, MINTER/IBAMA, 1990.

BRITISH STANDARDS INSTITUTION. Method for determination of apparent density after compaction of precipitated calcium carbonate. London, BSI, 1967.

CANIL, K. ; RIDENTE JUNIOR, J. L. A questão da erosão no contexto do gerenciamento dos recursos hídricos no estado de São Paulo. In: SEMINÁRIO SOBRE CIÊNCIA E DESENVOLVIMENTO SUSTENTÁVEL, São Paulo, 1997. Atas. São Paulo, Instituto de Estudos Avançados da 
USP/ Comissão de Estudos de Problemas Ambientais da USP, 1997. p. 112-3.

CONSELHO NACIONAL DA RESERVA DA BIOSFERA DA MATA ATLÂNTICA. Recuperação de áreas degradadas na Mata Atlântica: catálogo bibliográfico. São Paulo, CNRB, 1997.

COUILLARD, D. The use of peat in wastewater treatment: a review. Water Resources Research, v. 28, n. 6, p. 1261-74, 1994.

COUPAL, B.; LALANCETE, J. M. The treatment of wastewaters with peat moss. Water Research, v. 10, n. 12, p. 1071-6, 1976.

CURY, L. S. Permeabilidade dos solos. Rio de Janeiro, Instituto Nacional de Tecnologia, 1953. (Publicação, 4. Cursos do I.N.T.)

DANIELSON, R. E.; SUTHERLAND, P. L. Porosity. In: KLUTE, A., ed. Methods of soil analysis. Madison, American Society of Agronomy and Soil Science Society of America, 1987. v.1, p. 443-61. (Agronomy, 9)

DEDECEK, R. A. A dinâmica dos solos em áreas degradadas. In: SIMPÓSIO NACIONAL RECUPERAÇÃO DE ÁREAS DEGRADADAS, Curitiba, 1992. Anais. Curitiba, UFPR/FUPEF, 1992. p. 44-57.

DIAS, L. E.; FRANCO, A. A.;CAMPELLO, E. F. C. Dinâmica da matéria orgânica e de nutrientes em solo degradado pela extração de bauxita e cultivado com Eucalyptus pellita e Acacia mangium. In: SIMPÓSIO SULAMERICANO, 1./ SIMPÓSIO NACIONAL RECUPERAÇÃO DE ÁREAS DEGRADADAS, 2., Foz de Iguaçu, 1994. Anais. Curitiba, Fundação de Pesquisas Florestais do Paraná, 1994. p. 515-25.

DIAS, O. F. Técnicas e políticas de manejo e conservação dos solos. In: SIMPÓSIO SUL-AMERICANO, 1./ SIMPÓSIO NACIONAL RECUPERAÇÃO DE ÁREAS DEGRADADAS, 2., Foz de Iguaçu, 1994. Anais. Curitiba, Fundação de Pesquisas Florestais do Paraná, 1994. p. 199-204.

FRANCO, A. A. et al. Revegetação de áreas de mineração de bauxita em Porto Trombetas - PA com leguminosas arbóreas noduladas e micorrizadas. In: SIMPÓSIO SUL-AMERICANO, 1./ SIMPÓSIO NACIONAL RECUPERAÇÃO DE ÁREAS DEGRADADAS, 2., Foz de Iguaçu, 1994. Anais. Curitiba, Fundação de Pesquisas Florestais do Paraná, 1994. p. 145-53.

FRONZAGLIA, G. C. Análises quantitativas por difração de raios-X em engenharia mineral: aplicação dos métodos de Rietveld e do padrão interno. São Paulo, 1999. 152 p. Dissertação (Mestrado) - Escola Politécnica, Universidade de São Paulo. 
FUCHSMAN, C. H. Peat - industrial chemistry and technology. New York, Academic Press, 1980.

GARCIA, M. J. Palinologia de turfeiras quaternárias do médio vale do Rio Paraíba do Sul, Estado de São Paulo. São Paulo, 1994. 3v. Tese (Doutorado) - Instituto de Geociências, Universidade de São Paulo.

GRIFFITH, J. J.; DIAS, L. E.; JUCKSCH, I. Recuperação de áreas degradadas usando vegetação nativa. Saneamento Ambiental, v. 7, n. 37, p. 28-37, 1996.

HENIS, Y. Soil microorganisms, soil organic matter and soil fertility. In: INTERNATIONAL SYMPOSIUM ON PEAT IN AGRICULTURE AND HORTICULTURE, 2., Bet Dagan, 1983. Proceedings. Bet Dagan, Faculty of Agriculture. The Hebrew University of Jerusalem, 1983. p. 345-56.

INTERNATIONAL PEAT SOCIETY. On peat and peatlands: a short introduction. [On line]. Disponível através de http://www.peatsociety.fi [1997/12/19]. Arquivo capturado em 05/02/2000.

INSTITUTO DE PESQUISAS TECNOLÓGICAS DO ESTADO DE SÃO PAULO. Estudo das possibilidades de aproveitamento de turfa no Estado de São Paulo. São Paulo, IPT, 1979. (Relatório 12.761)

INSTITUTO DE PESQUISAS TECNOLÓGICAS DO ESTADO DE SÃO PAULO. Pesquisa de turfa e linhito no Vale do Paraíba. São Paulo, IPT, 1978. (Relatório 11.572)

JESUS, R. M. Revegetação: da teoria à prática - técnicas de implantação. In: SIMPÓSIO SUL-AMERICANO, 1./ SIMPÓSIO NACIONAL RECUPERAÇÃO DE ÁREAS DEGRADADAS, 2., Foz de Iguaçu, 1994. Anais. Curitiba, Fundação de Pesquisas Florestais do Paraná, 1994. p. 123-34.

KAGEYAMA, P. Y.; GANDARA, F.; BORGES, A. Pesquisa e recuperação de áreas degradadas na Mata Atlântica - avaliação bibliográfica. In: CONSELHO NACIONAL DA RESERVA DA BIOSFERA DA MATA ATLÂNTICA. Recuperação de áreas degradadas na Mata Atlântica: catálogo bibliográfico. São Paulo, CNRB, 1997. 72p.

KAGEYAMA, P. Y.; REIS, A.; CARPANEZZI, A. A. Potencialidades e restrições da regeneração artificial na recuperação de áreas degradadas. In: SIMPÓSIO NACIONAL RECUPERAÇẨO DE ÁREAS DEGRADADAS, Curitiba, 1992. Anais. Curitiba, UFPR / FUPEF, 1992. p. 1-7.

KIEHL, E. J. Aproveitamento da turfa na agricultura - caracterização e influência nas propriedades do solo. In: SEMINÁRIO SOBRE TURFA: PROSPECÇÃO, PRODUÇÃO E USOS, São Paulo, 1984. Palestras. São Paulo, CESP, 1985. p. 171-82. (Série Pesquisa e Desenvolvimento, 017) 
KLUTE, A. Water retention: laboratory methods. In: KLUTE, A., ed. Methods of soil analysis. Madison, American Society of Agronomy and Soil Science Society of America, 1987. v. 1, p. 635-62. (Agronomy, 9)

KLUTE, A. Laboratory measurement of hydraulic conductivity of unsaturated soil. In: BLACK, C. A. ed. Methods of soil analysis - Part 1: Physical and mineralogical properties, including statistics of measurement and sampling. Madison (WI), American Society of Agronomy and American Society for Testing Materials, 1979. p. 253-61. (Agronomy, 9)

KLUTE, A.; DIRKSEN, C. Hydraulic conductivity and diffusivity: laboratory methods. In: KLUTE, A., ed. Methods of soil analysis. Madison, American Society of Agronomy and Soil Science Society of America, 1987. v. 1, p. 687-734. (Agronomy, 9)

LEITE, L. L.; MARTINS, C. R.; HARIDASAN, M. Efeitos da descompactação e adubação do solo na revegetação espontânea de uma cascalheira no Parque Nacional de Brasília. In: SIMPÓSIO SUL-AMERICANO, 1./ SIMPÓSIO NACIONAL RECUPERAÇÃO DE ÁREAS DEGRADADAS, 2., Foz de Iguaçu, 1994. Anais. Curitiba, Fundação de Pesquisas Florestais do Paraná, 1994. p. 527-34.

LIBARDI, P. L. Dinâmica da água no solo. Piracicaba, O Autor, 1995.

LOPES, F. C. C. Painel sobre o $7^{\circ}$ Congresso Internacional de Turfa, realizado em Dublin - Irlanda (Junho de 1984), e sua correlação com a situação das turfas brasileiras. In: SEMINÁRIO SOBRE TURFA: PROSPECÇÃO, PRODUÇÃO E USOS, São Paulo, 1984. Palestras. São Paulo, CESP, 1985. p. 183-88. (Série Pesquisa e Desenvolvimento, 017)

LUCHESI, L. A. C. et al. Pastagens: um sistema de produção para a reabilitação de áreas degradadas. In: SIMPÓSIO NACIONAL RECUPERAÇÃO DE ÁREAS DEGRADADAS, Curitiba, 1992. Anais. Curitiba, UFPR / FUPEF, 1992. p. 83-92.

MARTINO, F. S. ; KURTH, G. M. Turfa - um combustível à espera de utilização. Energia - Fontes Alternativas, v. 20, n. 4, p. 64-71, 1982.

MASCHIO, J. H. et al. Evolução, estágio e caracterização da pesquisa em recuperação de áreas degradadas no Brasil. In: SIMPÓSIO NACIONAL RECUPERAÇÃO DE ÁREAS DEGRADADAS, Curitiba, 1992. Anais. Curitiba, UFPR / FUPEF, 1992. p. 17-33.

MONEGAT, C. A pequena propriedade: degradação, revegetação e outras práticas conservacionistas. In: SIMPÓSIO NACIONAL RECUPERAÇÃO DE ÁREAS DEGRADADAS, Curitiba, 1992. Anais. Curitiba, UFPR / FUPEF, 1992. p. 97-106. 
MOTTA NETO, J. A; MORAES, A.; RIBEIRO JUNIOR, P. J. Avaliação do uso de forrageiras e de adubações na recuperação de um solo degradado pela mineração do xisto II: Propriedades físicas. In: SIMPÓSIO SULAMERICANO, 1./ SIMPÓSIO NACIONAL RECUPERAÇÃO DE ÁREAS DEGRADADAS, 2., Foz de Iguaçu, 1994. Anais. Curitiba, Fundação de Pesquisas Florestais do Paraná, 1994a. p. 257-65.

MOTTA NETO, J. A; MORAES, A.; RIBEIRO JUNIOR, P. J. Avaliação do uso de forrageiras e de adubações na recuperação de um solo degradado pela mineração do xisto I: Propriedades químicas. In: SIMPÓSIO SULAMERICANO, 1./ SIMPÓSIO NACIONAL RECUPERAÇÃO DE ÁREAS DEGRADADAS, 2., Foz de Iguaçu, 1994. Anais. Curitiba, Fundação de Pesquisas Florestais do Paraná, 1994b. p. 247-56.

MUNSHOWER, F. F. Practical handbook of disturbed land revegetation. Boca Raton, Lewis Publishers, 1994.

OGURA, A. T. et al. A dinâmica dos processos de erosão e assoreamento e a gestão dos recursos hídricos. In: SIMPÓSIO BRASILEIRO DE RECURSOS HÍDRICOS, 12., Vitória, 1997. Atas. São Paulo, ABRH, 1997. v. 3, p. 55560.

OLIVEIRA, J. B. Solos do estado de São Paulo: descrição das classes registradas no mapa pedológico. Campinas, Instituto Agronômico, 1999. (Boletim Científico IAC, n. 45)

PETRONI, S. L. G. Estudos de adsorção de zinco e cádmio em turfa potencialidade de utilização de um bioadsorvedor natural em sistemas de tratamento de efluentes. São Paulo, 1999. 99p. Dissertação (Mestrado) - Instituto de Pesquisas Energéticas e Nucleares, Universidade de São Paulo.

PLASS, W. T. Use of mulches and soil stabilizers for land reclamation in the Eastern United States. In: SCHALLER, F. W. ; SUTTON, P., eds. Reclamation of drastically disturbed lands. 2.ed. Madison, American Society of Agronomy / Crop Science Society of America / Soil Science Society of America, 1981. p. 329-37.

PRIMAVESI, A. Manejo ecológico do solo: a agricultura em regiões tropicais. 6. ed. São Paulo, Nobel, 1984.

RATTI, G. Análises químicas na engenharia mineral. São Paulo, 1994. 83 p. Tese (Doutorado) - Escola Politécnica, Universidade de São Paulo.

REICHARDT, K. Processos de transferência no sistema solo-plantaatmosfera. 4.ed. Campinas, Fundação Cargill, 1985.

SÁNCHEZ, L. E. Projetos de recuperação: usos futuros e a relação com a comunidade. In: ENCONTRO DE MINERAÇÃO NO MUNICÍPIO DE SÃO 
PAULO: SITUAÇÃO ATUAL E PERSPECTIVAS, 1, São Paulo, 1994. Anais. São Paulo, PREFEITURA DO MUNICÍPIO DE SÃO PAULO, 1995. p. 55-73.

SÃO PAULO. Secretaria de Energia e Saneamento. Departamento de Águas e Energia Elétrica. Controle de erosão - bases conceituais e técnicas: diretrizes para o planejamento urbano e regional; orientações para 0 controle de boçorocas urbanas. 2.ed. São Paulo, DAEE/IPT, 1990.

SILVA, I. X. et al. Recuperação de áreas degradadas por extração de areia no município de Jacareí - SP. In: SIMPÓSIO SUL-AMERICANO, 1./ SIMPÓSIO NACIONAL RECUPERAÇÃO DE ÁREAS DEGRADADAS, 2., Foz de Iguaçu, 1994. Anais. Curitiba, Fundação de Pesquisas Florestais do Paraná, 1994. p. 205-10.

STEVENSON, F. J. Humus chemistry: genesis, composition, reactions. 2.ed. New York, John Wiley, 1994.

SUSZCZYNSKI, E. F. Turfa - o novo combustível nacional. Energia - Fontes Alternativas, v. 20, n. 4, p. 6-61, 1982.

TAN, H. T. Principles of soil chemistry. 2.ed. New York, Marcel Dekker, 1993.

WISNIEWSKI, A. T. et al. O uso do lodo de esgoto da ETE - Belém na recuperação de áreas degradadas por mineração de calcário. Sanare, v. 7 , p. 76-85, jan. 1997. 